\title{
GROUND-WATER FLOW SIMULATION OF THE COLUMBIA PLATEAU \\ REGIONAL AQUIFER SYSTEM, WASHINGTON, OREGON, AND IDAHO
}

By A. J. Hansen, Jr., J. J. Vaccaro, and H. H. Bauer

A Contribution of the

Regional Aquifer-System

Analysis Program

U.S. GEOLOGICAL SURVEY

Water-Resources Investigations Report 91-4187

Tacoma, Washington 


\title{
U.S. DEPARTMENT OF THE INTERIOR
}

\author{
BRUCE BABBITT, Secretary
}

\author{
U.S. GEOLOGICAL SURVEY
}

\author{
Gordon P. Eaton, Director
}

Any use of trade, product, or firm names is for descriptive purposes only and does not imply endorsement by the U.S. Government.

For more information

write to:

District Chief

U.S. Geological Survey

1201 Pacific Avenue, Suite 600

Tacoma, Washington 98402-4384
Copies of this report may be purchased from:

U.S. Geological Survey

Earth Science Information Center

Open-File Reports Section

Box 25286, MS 517

Denver Federal Center

Denver, CO 80225 


\section{CONTENTS}

Abstract

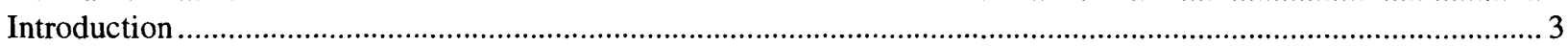

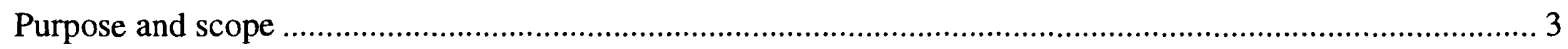

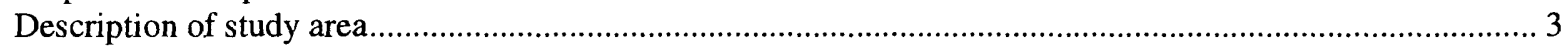

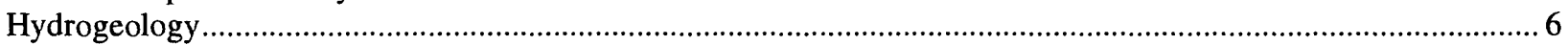

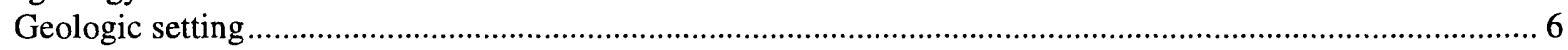

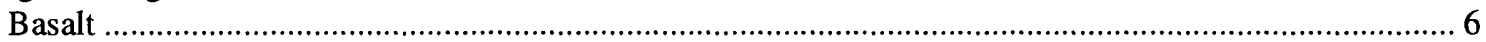

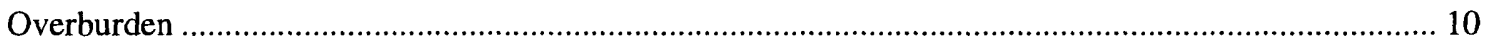

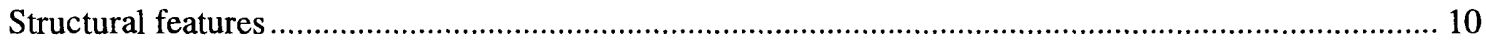

Conceptual model for ground-water movement and numerical simulation ............................................... 11

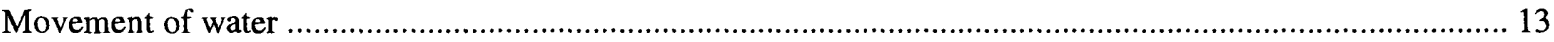

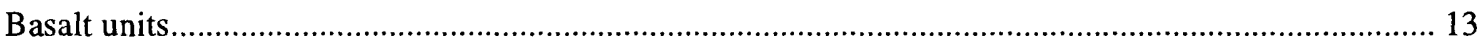

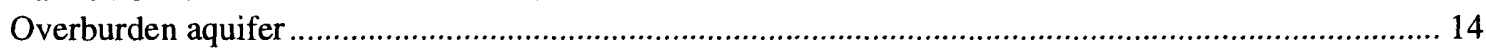

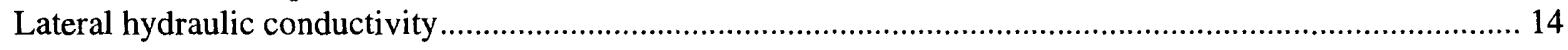

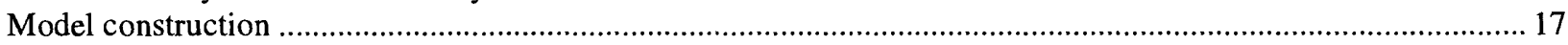

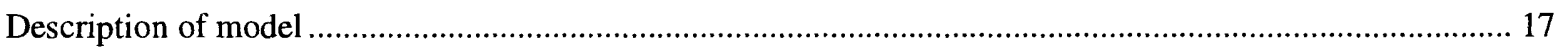

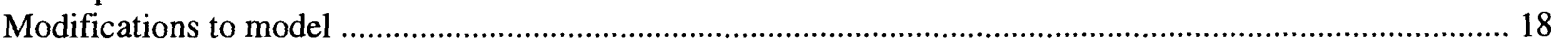

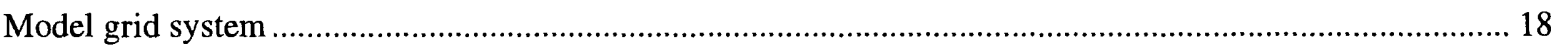

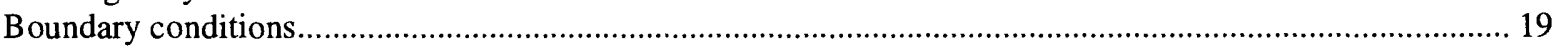

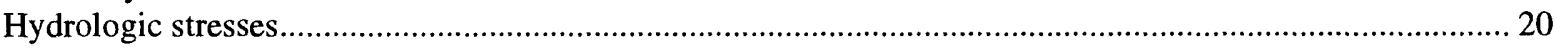

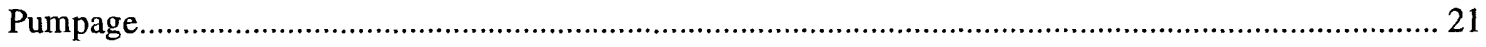

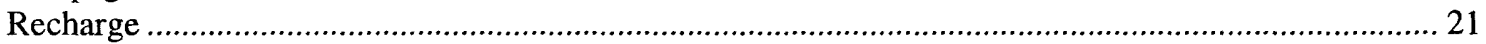

Change in storage

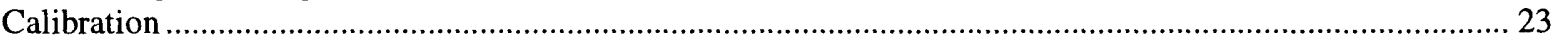

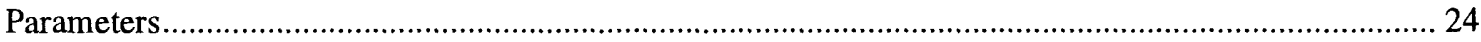

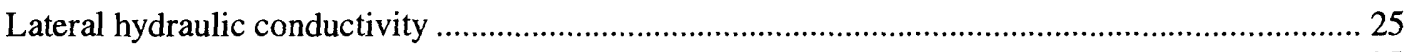

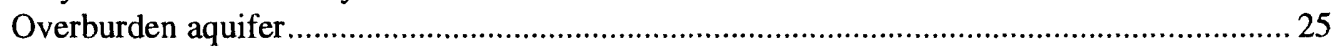

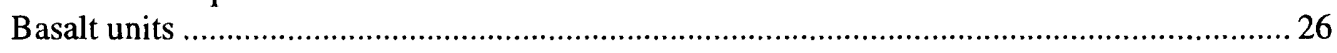

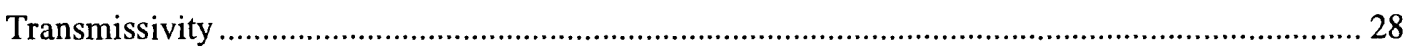

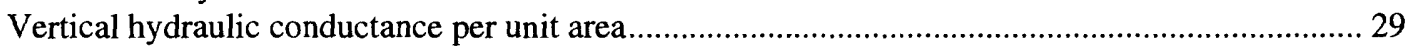

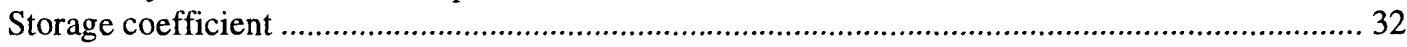

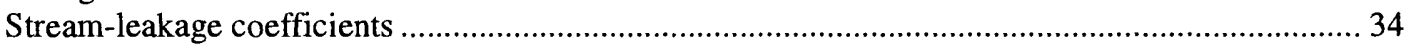

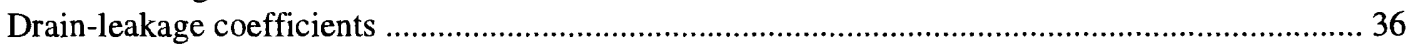

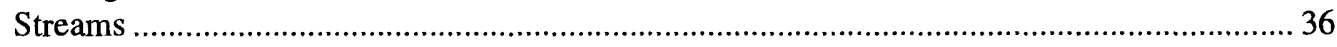

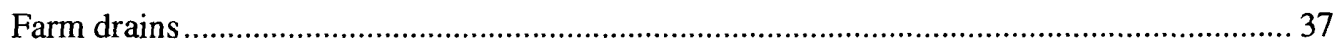

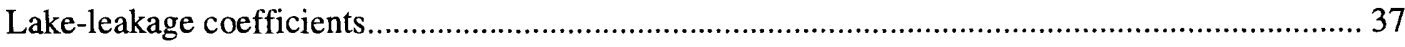

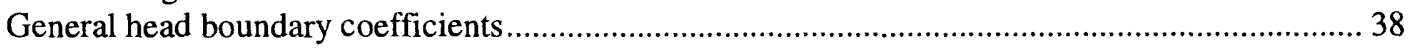

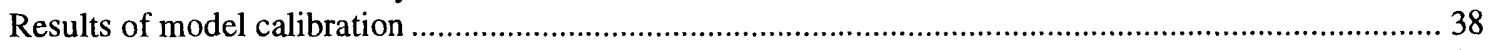

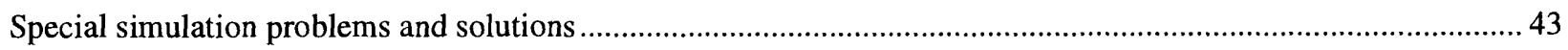

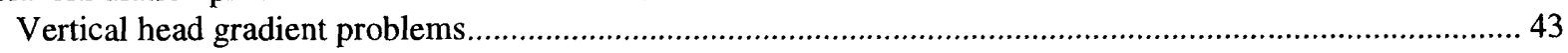

Lateral head gradient problems ............................................................................................................... 44

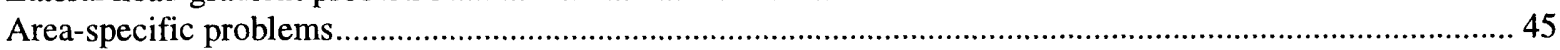

Numerical problems, model limitations, and sensitivity …................................................................... 47

Discussion of the regional flow system on the basis of model simulations........................................................... 54

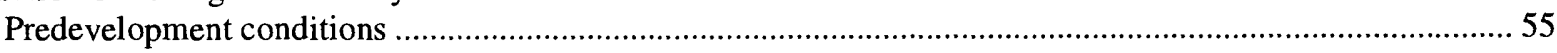

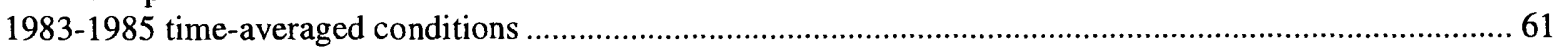

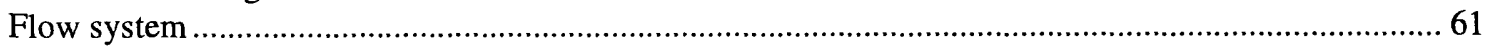

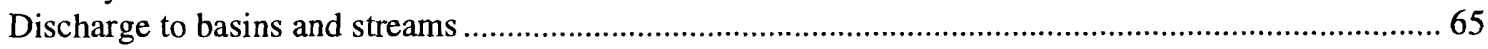

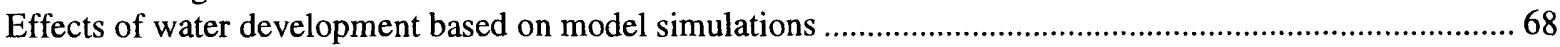

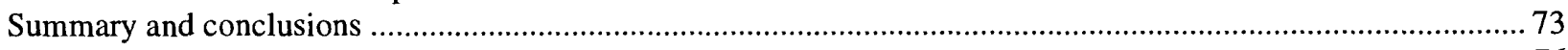

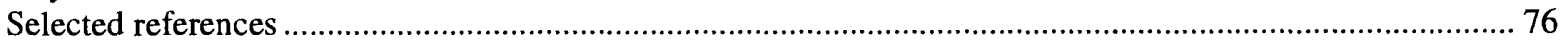




\section{ILLUSTRATIONS}

[Plates are located in jacket at end of report]

PLATE 1. Maps showing the geologic framework for the Columbia Plateau aquifer system, Washington, Oregon, and Idaho.

2. Maps showing the model grid system and boundary conditions for the Columbia Plateau aquifer system, Washington, Oregon, and Idaho.

3. Maps showing average ground-water pumpage 1983-85 in the Columbia Plateau aquifer system, Washington, Oregon, and Idaho.

4. Maps showing the mean annual precipitation and estimates of recharge for the Columbia Plateau aquifer system, Washington, Oregon, and Idaho.

5. Maps showing model-derived distribution of lateral hydraulic conductivity in the model layers for the Columbia Plateau aquifer system, Washington, Oregon, and Idaho.

6. Maps showing model-derived distribution of transmissivity in the model layers for the Columbia Plateau aquifer system, Washington, Oregon, and Idaho.

7. Maps showing model-derived distribution of vertical hydraulic conductance per unit area between model layers for the Columbia Plateau aquifer system, Washington, Oregon, and Idaho.

8. Maps showing locations and types of cells or areas where model-calculated discharge or water budgets are presented for the Columbia Plateau aquifer system, Washington, Oregon, and Idaho.

9. Maps showing observed and time-averaged, model-calculated water-level contours for the model layers for the Columbia Plateau aquifer system, Washington, Oregon, and Idaho.

10. Maps showing areal distribution of predevelopment (1850's) model-calculated ground-water flow through the bottom of the model layers for the Columbia Plateau aquifer system, Washington, Oregon, and Idaho.

11. Maps showing predevelopment (1850's) model-calculated head difference between the model layers for the Columbia Plateau aquifer system, Washington, Oregon, and Idaho.

12. Maps showing time-averaged, model-calculated water-level contours for the model layers for the Columbia Plateau aquifer system, Washington, Oregon, and Idaho.

13. Maps showing areal distribution of time-averaged, model-calculated ground-water flow through the bottom of the model layers for the Columbia Plateau aquifer system, Washington, Oregon, and Idaho.

14. Maps showing time-averaged, model-calculated head difference between the model layers for the Columbia Plateau aquifer system, Washington, Oregon, and Idaho.

15. Maps showing model-calculated water-level changes between the time-averaged and predevelopment (1850's) simulations for the model layers for the Columbia Plateau aquifer system, Washington, Oregon, and Idaho. 


\section{ILLUSTRATIONS--Continued}

FIGURE 1. Map showing location of the study area and physiographic and cultural features 5

2. Sketch showing internal structure of an individual basalt flow 7

3. Correlation chart of the geologic framework, hydrologic framework, and ground-water model layers for the Columbia Plateau. 8

4. Graph showing frequency distribution of hydraulic-conductivity data for the overburden aquifer. 15

5. Graph showing frequency distribution of hydraulic-conductivity data for the basalt units 16

6. Graph showing frequency distribution for class intervals of the difference between time-averaged, model-calculated heads and observed heads for the top four model layers.

7. Generalized diagrammatic hydrogeologic section showing idealized ground-water flow and the concept of local, intermediate, and regional flow systems

8. Schematic diagram showing the model-calculated predevelopment ( 1850 's) water budget 56

9. Schematic diagram showing the model-calculated 1983-85 time-averaged water budget 59

10. Schematic diagram showing the model-calculated water budget change from predevelopment to time-averaged conditions.

\section{TABLES}

TABLE 1. Descriptive statistics of lateral hydraulic conductivity for the model layers 25

2. Descriptive statistics of transmissivity for the model layers 28

3. Descriptive statistics of vertical hydraulic conductance per unit area for the upper four model layers 31

4. Summary of selected storage-coefficient estimates for the Columbia Plateau 33

5. Descriptive statistics for the stream- and drain-leakage and general-head-boundary coefficients 36

6. Component sensitivity for selected model variables representing calculated change in head due to uniform change in a variable. 


\section{TABLES--Continued}

TABLE 7. Calculated water budget for the predevelopment and time-averaged simulations for the regional aquifer system.

8. Calculated water budget for the predevelopment and time-averaged simulations

for the model layers

9. Calculated ground-water discharge within selected drainage basins for the time-averaged simulation

10. Model-calculated ground-water discharge to selected river reaches

\section{CONVERSION FACTORS AND VERTICAL DATUM}

\begin{tabular}{lcl} 
Multiply & By & To obtain \\
\hline inch (in.) & 25.40 & millimeter \\
foot (ft) & 0.3048 & meter \\
mile (mi) & 1.609 & kilometer \\
square foot $\left(\mathrm{ft}^{2}\right)$ & 0.0929 & square meter \\
acre & 0.4047 & hectare (ha) \\
square mile $\left(\mathrm{mi}^{2}\right)$ & 2.590 & square kilometer \\
cubic mile $\left(\mathrm{mi}^{3}\right)$ & 4.168 & cubic kilometer \\
foot per second $(\mathrm{ft} / \mathrm{s})$ & 0.3048 & meter per second \\
foot per day $(\mathrm{ft} / \mathrm{d})$ & 0.3048 & meter per day \\
foot squared per second $\left(\mathrm{ft}^{2} / \mathrm{s}\right)$ & 0.09290 & meter squared per second \\
cubic foot per second $\left(\mathrm{ft}^{3} / \mathrm{s}\right)$ & 0.02832 & cubic meter per second \\
pound per square inch $\left(\mathrm{lb} / \mathrm{in}^{2}\right)$ & 6.895 & kilopascal $(\mathrm{kPa})$
\end{tabular}

Sea level: In this report, "sea level" refers to the National Geodetic Vertical Datum of 1929 (NGVD of 1929)--a geodetic datum derived from a general adjustment of the first-order level nets of both the United States and Canada, formerly called Sea Level Datum of 1929. 


\title{
GROUND-WATER FLOW SIMULATION OF THE COLUMBIA PLATEAU REGIONAL AQUIFER SYSTEM, WASHINGTON, OREGON, AND IDAHO
}

\author{
By A. J. Hansen, Jr., J. J. Vaccaro, and H. H. Bauer
}

\begin{abstract}
A thick sequence of flood basalts of Miocene age covering 50,600 square miles forms a major aquifer system in eastern Washington, eastern Oregon, and a small part of Idaho. About 4,509 square miles of saturated sedimentary overburden materials overlie the basalts, mainly in the central part of the Columbia Plateau. Together, the sedimentary and basalt materials make up the Columbia Plateau regional aquifer system.

The aquifer system, for study purposes, was divided into four aquifer units and three confining units. The aquifer units are, from youngest to oldest, the overburden aquifer, the Saddle Mountains unit, the Wanapum unit, and the Grande Ronde unit. For modeling purposes, the Grande Ronde unit is separated into two layers, the upper and lower Grande Ronde. The base of the aquifer system is composed of rock materials older than the basalts and is called the basement confining unit. The other two confining units are generally equivalent, and are from youngest to oldest, the Saddle Mountains-Wanapum interbed and the Wanapum-Grande Ronde interbed. The Wanapum-Grande Ronde interbed is not mapped fully and is missing in several locations. These two confining units are areally extensive but extremely thin when compared with the thickness of the basalts. The two interbeds, however, are productive aquifers in some areas.
\end{abstract}

A numerical finite-difference ground-water model covering 32,688 square miles was used to simulate the regional flow system. The model consists of 5 layers and 17,899 cells. A time-averaged, steady-state approach was used for model construction. The model parameters initially were estimated for a steady-state simulation representing predevelopment conditions. Subsequently, the model was calibrated to the 1983-85 period. After calibration of the time-averaged (1983-85 period) model, the steady-state, predevelopment flow system was simulated.

Recharge to the aquifer system is mainly from precipitation and irrigation. Recharge ranges from zero in low-lying areas that receive precipitation of less than 8 inches annually, to more than 30 inches per year in the mountainous and irrigated areas. Recharge was estimated to be 6,568 cubic feet per second ( 2.72 inches per year) for predevelopment conditions and 10,208 cubic feet per second ( 4.24 inches per year) for time-averaged conditions. For cells receiving more than about 3 inches per year of recharge, 25 percent discharges locally; whereas, for cells receiving less than 3 inches per year and where there are no major rivers draining the regional system, less than 5 percent discharges locally.

Initial mapping of lateral hydraulic conductivities in the basalts showed little spatial correlation between conductivities. Such randomness initially was assumed to be in areas lacking specific-capacity data, such as in the folded uplands. To achieve calibration, however, small values were estimated for the uplands and large values were estimated for low-lying areas near major discharge features. The model-derived lateral hydraulic conductivity of the overburden aquifer has a median of about $5 \times 10^{-4}$ feet per second and ranges from about $5 \times 10^{-7}$ to $13 \times 10^{-3}$ feet per second. Conductivities of the basalt range from about $1 \times 10^{-6}$ to $1 \times 10^{-4}$ feet per second and have a median of about $1.7 \times 10^{-5}$ feet per second. 
Few data are available for vertical conductances. Model-calibrated values for all units range from $4.5 \times 10^{-13}$ to $1.0 \times 10^{-5}$ per second. The model-calibrated distribution of vertical conductances generally shows low values in the upland, folded areas and over broad, low-lying areas surrounding the major rivers. Vertical conductances in the two uppermost layers, however, were made anomalously large for model cells beneath the major rivers. One probable explanation for such large conductances is that these rivers cut deeply into the basalts and were backfilled with coarse materials.

Recharge is the principal inflow component to the flow system during the predevelopment and the time-averaged periods. Leakage from rivers provides an average of 555 cubic feet per second of inflow for both periods. Discharge from the aquifer system is by leakage to rivers, leakage to drains, and ground-water pumpage. Leakage to rivers and drains during predevelopment conditions was about 2,750 and 3,940 cubic feet per second, respectively, and for the time-averaged conditions was 3,800 and 5,600 cubic feet per second, respectively. Time-averaged conditions have the additional discharge component of ground-water pumpage, 1,135 cubic feet per second $(822,000$ acre-feet).

The root-mean-square head residual for the upper three model layers is about 100 feet $(70$ percent of the differences between calculated and observed heads is less than 100 feet). The root-mean-square error for the upper Grande Ronde is about 292 feet. A comparison of manually contoured head configurations with model-calculated configurations shows good agreement over much of the modeled area.

The use of water associated with water development has increased recharge by 3,640 cubic feet per second, saturated previously unsaturated rock materials, and caused water-level declines. Increase in recharge and volume of saturated materials is due to the infiltration of surface water applied to croplands. Water-level rises have been more prevalent and widespread than water-level declines. This is because a larger area of croplands is irrigated with surface water rather than with ground water. The average surface-water annual application rate is about 4 feet per year. Water-level declines have occurred mainly in the Odessa-Lind area, the Umatilla area, the Horse Heaven Hills area, the Pullman-Moscow area, the Walla Walla River area, and in some of the small tributary valleys to the Yakima River. Water-level changes in the top four layers vary by more than 200 feet. Of 27 basins analyzed, 17 show a decrease in ground-water discharge. The discharge within the remaining basins either stayed the same or increased slightly. 


\section{INTRODUCTION}

A study of the Columbia Plateau regional aquifer system began in October 1982 as one of the 28 studies of the U.S. Geological Survey's Regional Aquifer-System Analysis Program (RASA). The purpose of the RASA program is to aid in the effective management of the Nation's important ground-water resources by providing information on the geohydrology and geochemistry of the regional aquifer systems, as well as on analytical capabilities necessary to assess management alternatives.

The Columbia Plateau aquifer system is in the Columbia Plateau of central and eastern Washington, north-central and northeastern Oregon, and a small part of northwestern Idaho. The aquifer system underlies about $50,600 \mathrm{mi}^{2}$ and is composed mainly of the Columbia River Basalt Group of Miocene age with relatively minor amounts of interbedded sediments and overlying sediments of Miocene to Holocene age.

The Columbia Plateau aquifer system is a major source of water supply in the study area. Imported and local surface water also is used for irrigation on the plateau. Water levels have risen as much as $300 \mathrm{ft}$ in areas of surface-water irrigation and declined more than $150 \mathrm{ft}$ in areas of ground-water pumping. Irrigation practices have changed the chemical quality of ground water in places.

The objectives of the Columbia Plateau study are to describe (1) the geologic framework, (2) the hydraulic characteristics, (3) the water budget, (4) the flow system, and (5) the water-quality characteristics and water-rock interactions that occur in the regional aquifer system (Vaccaro, 1986). A final objective is to provide a means of projecting the aquifer system's response to ground-water development. The method used to meet this last objective was to construct a numerical ground-water model. A numerical model is an efficient tool for interpreting the regional ground-water flow system, the relations among the components of the flow system, and for assessing the conceptual model of ground-water flow. The Columbia Plateau aquifer system in the ground-water model boundaries underlies about $32,688 \mathrm{mi}^{2}$.

\section{Purpose and Scope}

The purposes of this report are to (1) document the steady-state (estimate of predevelopment conditions) and time-averaged (spring 1983 to spring 1985) numerical models of ground-water flow, and (2) describe the geologic framework, the hydraulic characteristics, the water budget, the hydrology of the Columbia Plateau aquifer system, and the changes in the hydrologic system from predevelopment to current conditions. More detailed analyses of item (2) above are presented in the companion reports of Drost and Whiteman (1986), Gonthier (1990), Drost and others (1990), Bauer and others (1985), Bauer and Vaccaro (1987; 1990), Whiteman (1986), Cline and Knadle (1990), Collins (1987), Cline and Collins (1992), Steinkampf (1989), and Lane and Whiteman (1989). The source code for the ground-water flow model and the input and output files have been archived by Hansen (1993b).

\section{Description of Study Area}

The Columbia Plateau aquifer system is in the Columbia Intermontane physiographic province (Freeman and others, 1945). The study area is bordered by the Cascade Range on the west, by the Okanogan Highlands on the north, and by the Rocky Mountains on the east. The southern boundary of the aquifer system has no well-defined physiographic feature and is defined as the extent of the mapped Columbia River Basalt Group. The southern boundary for the ground-water flow model is delineated by a series of outcrops of the older pre-Columbia River Basalt Group "basement" rocks, by the Blue Mountains anticline, and finally, by the deeply incised Grande Ronde River. Thus, the southern boundary is a hydrogeologic-extent boundary. The relation of the model boundary to the major physiographic features and to the extent of the Columbia River Basalt Group is shown in plate 1a. 
The study area has been divided further by Myers and Price (1979) into three informal physiographic subprovinces--the Yakima Fold Belt, the Blue Mountains, and the Palouse subprovinces (plate 1a). Together these subprovinces make up a structural and topographic basin. The Yakima Fold Belt, located in the western part of the study area, is characterized by long, narrow, east-west-trending anticlinal ridges with intervening broad to narrow synclinal basins. The Palouse subprovince consists of a gentle, southwest-sloping, undeformed basalt with a developed rolling topography. The Blue Mountains subprovince in the southeastern part of the study area consists of dissected upland plateaus. Physiographic and cultural features referenced in this report are shown on figure 1.

The study area is within the drainage of the Columbia River. Major tributaries to the Columbia River in the study area include the Snake, Yakima, John Day, Umatilla, Klickitat, and Deschutes Rivers. These tributaries drain the bordering mountainous areas. Land-surface altitudes and precipitation largely determine the types and amounts of natural vegetation found in the Columbia Plateau. Precipitation ranges from 6 to $15 \mathrm{in} / \mathrm{yr}$ (inches per year) in the central part of the plateau at altitudes from 350 to $2,000 \mathrm{ft}$ above sea level. Here the vegetation is principally sage and grasslands, and few streams are perennial. At intermediate altitudes (2,000 to 3,500 ft), precipitation ranges from 15 to $25 \mathrm{in} / \mathrm{yr}$. Here the vegetation is more typical of semiarid climates and includes both grasslands and forest. Forest lands predominate at altitudes greater than $3,500 \mathrm{ft}$, where precipitation is greatest and where smaller, dissected perennial streams are common. The distribution of mean annual precipitation for the period 1956 to 1977 is shown on plate $4 \mathrm{a}$.

The predominant economic activities in the study area are agriculture and its associated services. In 1984, nearly $780 \mathrm{mi}^{2}$ of cropland were irrigated with ground water and about $1,950 \mathrm{mi}^{2}$ of cropland were irrigated with surface water. There are currently about $4,200 \mathrm{mi}^{2}$ (Wukelic and others, 1981) of dryland crops that can be converted to irrigated croplands. In addition, there are some 5,000 to $7,000 \mathrm{mi}^{2}$ of sage and grasslands that could be converted to irrigated crops. 


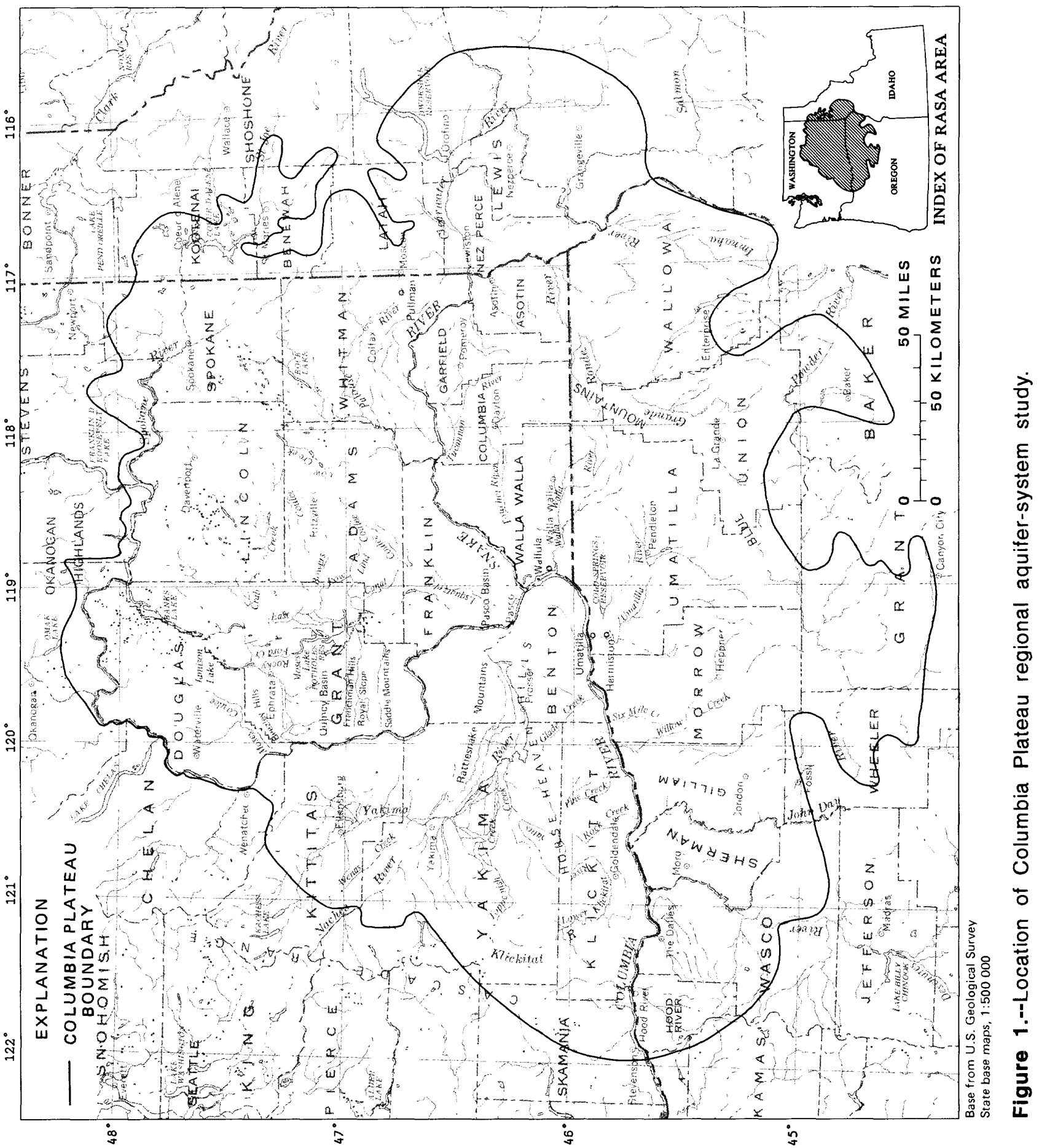




\section{HYDROGEOLOGY}

The following subsections describe the geologic setting, the relation between the geologic and hydrologic framework that provides the basis for the regional conceptual model for ground-water movement, the movement of water within the four study units, and the initial characterization of the lateral hydraulic conductivity of the aquifer units. Together, these discussions provide the framework for construction of the numerical ground-water flow model and for the description of the ground-water flow in the regional aquifer system.

\section{Geologic Setting}

\section{Basalt}

That part of the Columbia Plateau underlain by rocks of the Columbia River Basalt Group is both a structural and topographic basin with its lowest point near Pasco, Wash. (fig. 1 and plate 1a). Rocks underlying the plateau are the Miocene-age Columbia River Basalt Group and the intercalated and overlying sediments collectively assigned to the Ellensburg, Latah, Ringold, and Palouse Formations, and the Dalles Group and alluvium of Miocene to Holocene age. The Columbia River Basalt Group covers an area of about $63,200 \mathrm{mi}^{2}$ and has an estimated volume of $39,300 \mathrm{mi}^{3}$ (Tolan and others, 1987). Along the borders of the plateau, the basalts are underlain by Precambrian to early Tertiary "basement" rocks of mostly volcanic and metamorphic origin. Sedimentary rocks underlie the basalts in the Yakima Fold Belt and in adjacent parts of the plateau to the east, and volcanic and metamorphic rocks underlie the basalts in the other subprovinces.

Basalt erupted from about 17 to 6 million years B.P. (before present). Most flows extruded during a short period centered around 15 million years B.P., exceeding $13,000 \mathrm{mi}^{3}$ of lava per million years. Eruptions were less frequent and less voluminous from 14 to 6 million years B.P. (averaging about $0.25 \mathrm{mi}^{3}$ per million years). This allowed time for erosion, deformation, and increased deposition of sediment between eruptions (Swanson and Wright, 1978; Camp and others, 1982). This basaltic lava extruded from a system of northwest-trending linear vents in southeastern Washington, northeastern Oregon, and western Idaho (Hooper, 1982; Swanson and others, 1975). Basin subsidence was concurrent with extrusion; thus the lava flows thin progressively outward from the basin axis.

Extrusion and cooling of individual flows under different physical settings resulted in the formation of columnar joints, pillow lavas, and brecciated flow tops. Individual basalt flows range in thickness from a few inches to more than $300 \mathrm{ft}$ and average about $100 \mathrm{ft}$. The internal structure of a typical flow generally consists of, from bottom to top, a flow base, a colonnade, an entablature, and a flow top (fig. 2). The base of a flow generally has a thin zone of glassy basalt, a vesicular zone, and might include a zone of pillow basalt. Porous pillow-palagonite complexes, caused by underwater cooling, commonly are present at the base. The colonnade consists of nearly vertical three- to eight-sided columns of basalt that average about $3 \mathrm{ft}$ in diameter and about $25 \mathrm{ft}$ in length. The columns were formed by vertical jointing that occurred during the slow cooling and contraction of the flow interior. Columns commonly are crosscut by systems of joints. The denser entablature consists of small-diameter (averaging less than $2 \mathrm{ft}$ ) basalt columns in fan-shaped arrangements. Cross joints in the entablature are oriented and interconnected less consistently than in the colonnade. Hackly joints are common in the upper part of the entablature, which is commonly vesicular. The flow top generally consists of vesicular basalt with scoria and clinker, and averages about 5 to 10 percent of the total thickness of a single flow (fig. 2). The flow top in combination with the superposed flow base is called the interflow zone. 


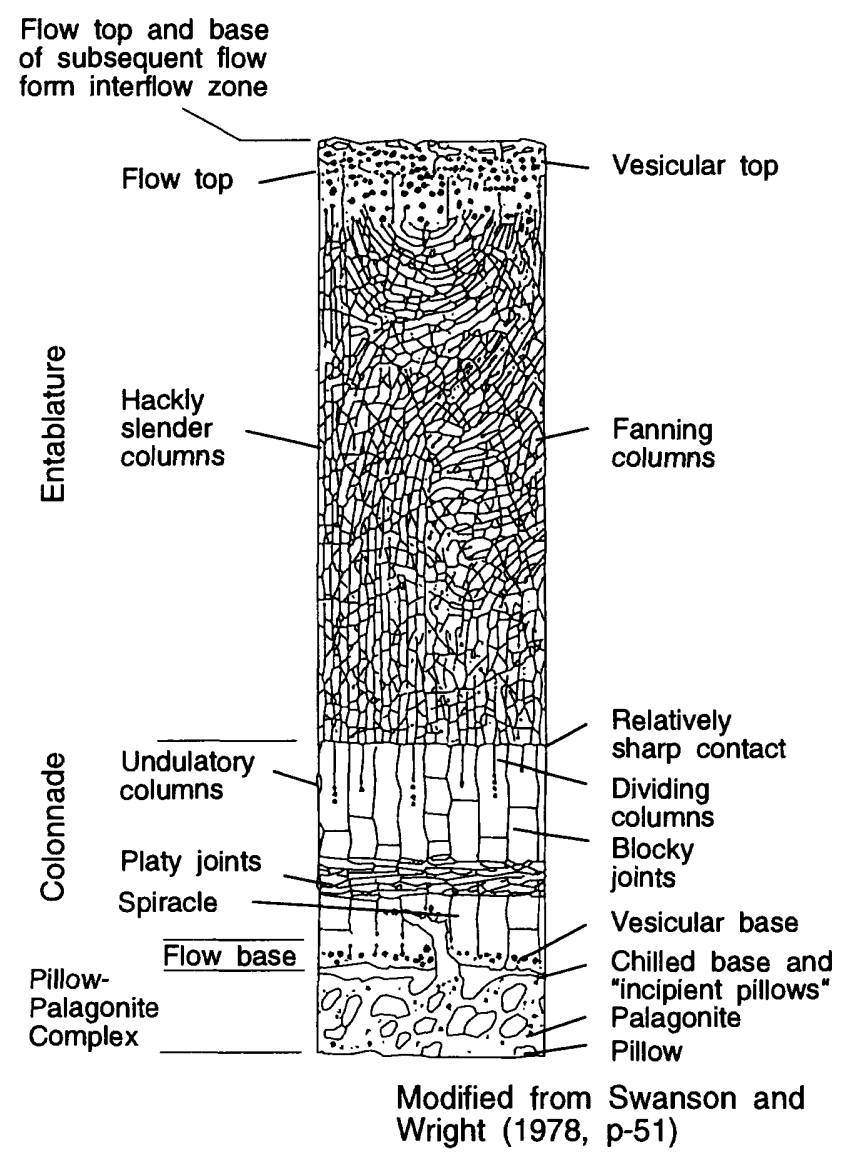

Figure 2.--Sketch showing internal structure of an individual basalt flow.

The Columbia River Basalt Group has been subdivided stratigraphically into five formations and numerous members, as shown on figure 3 (Swanson and others, 1979c). The Yakima Basalt Subgroup of the Columbia River Basalt Group is the most extensive and hydrologically important and consists of, from oldest to youngest, the Grande Ronde, Wanapum, and Saddle Mountains Basalt. Pre-Yakima basalts, which consist of the Imnaha and Picture Gorge Basalts, have been mapped only in scattered locations in the southern and southeastern parts of the plateau, and these outcrops lie mostly outside the modeled area. Except for a small part of the Imnaha Basalt, the pre-Yakima basalts were not analyzed in this study because of their limited extent and the location of the boundaries of the ground-water model.

The geologic maps of the Columbia River Basalt Group of Swanson and others (1979a, b) have been modified for the Grande Ronde, Wanapum, and Saddle Mountains Basalts by Drost and Whiteman (1986) for Washington and by Gonthier (1990) for Oregon. This work later was extended into Idaho, and maps describing the geologic framework for the Columbia Plateau aquifer system have been published by Drost and others (1990). Thickness maps were constructed during these studies for the Saddle Mountains and Wanapum Basalts, including the intercalated sediments, and for the Saddle Mountains-Wanapum and Wanapum-Grande Ronde interbeds (fig. 3). The basalt thickness maps thus represent the complete thickness of the basalt formations plus their intercalated sediments, and the units they represent herein are called the Saddle Mountains and Wanapum units to distinguish them from the formations, which do not include intercalated sediments. A thickness map for the Grande Ronde 
Basalt, its intercalated sediments, and a small part of the Imnaha Basalt was compiled during the modeling effort. These combined rock materials are called the Grande Ronde unit, and the construction of this map is discussed below. Excluding the overlying sediments, the contours of thickness presented in plate 1 include all interbeds. Excluding the Grande Ronde unit, these thickness maps are based on gridded-averaged values of the tops of hydrogeologic units and thickness information of Drost and others (1990). The thickness maps on plate 1 are a good representation of average basalt unit thickness because the thickness of the interbeds is much smaller than the basalt thickness.

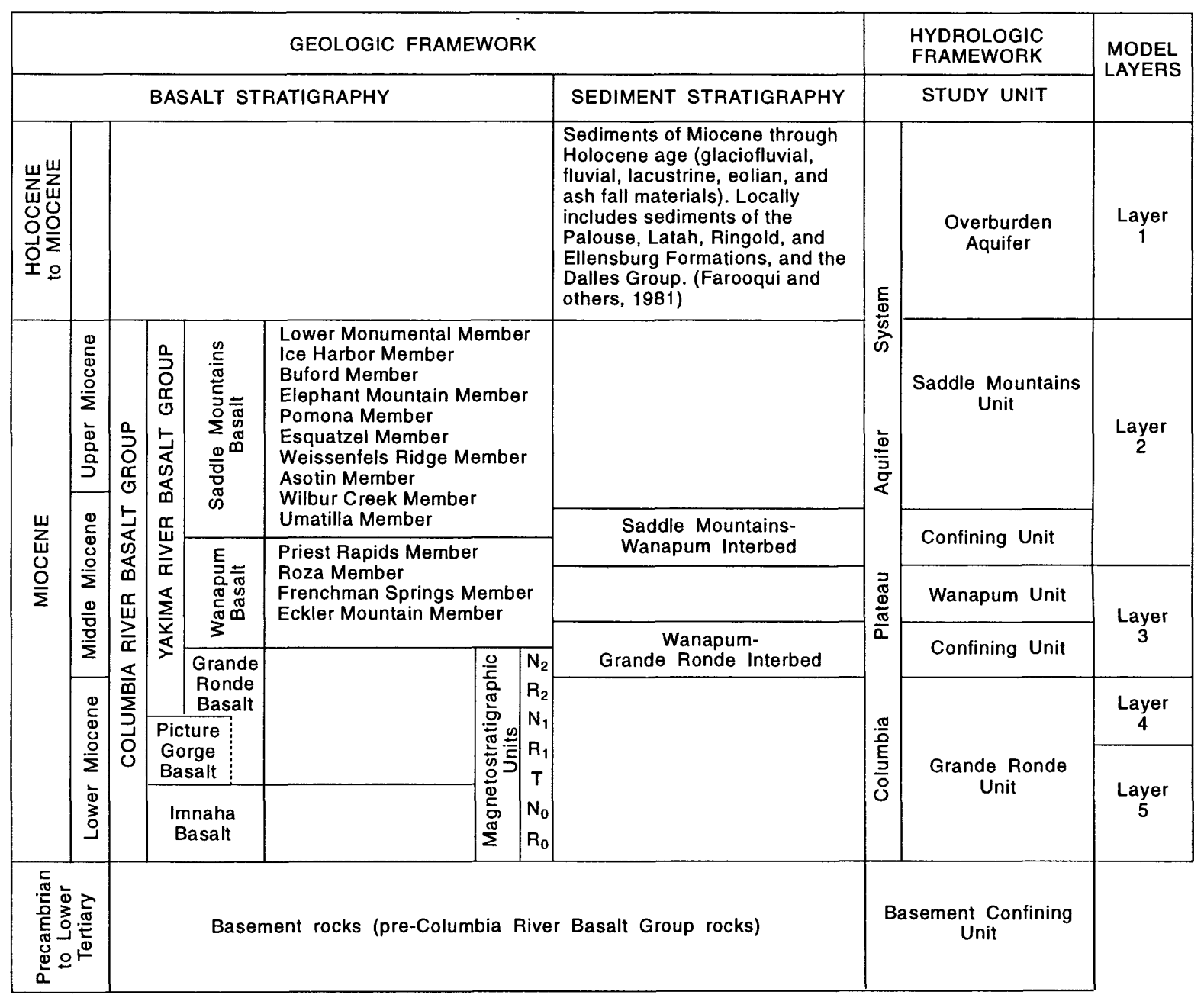

Figure 3.--Correlation chart of the geologic framework, hydrologic framework, and ground-water model layers for the Columbia Plateau. (Modified from Swanson and others, 1979c.) 
The method used to construct these maps was to digitize the structure contours of the top of the Saddle Mountains, Wanapum, and Grande Ronde Basalts. The digitized contours were then interpolated to each cell. Average land-surface altitude, calculated from the 1:250,000-scale DEMs (Elassal and Caruso, 1983), were assigned as the top of the surficial (outcrop) unit. Digitized thickness contours of the overburden aquifer, the Saddle Mountains unit, and the Wanapum unit (the latter two contour maps include the intervening confining units as mapped by Drost and others, 1990) also were interpolated to each cell. The two sets of gridded data were then contoured in order to verify that, when contoured, they reproduced the published contours; values were edited manually for some cells in order to meet this criterion.

The gridded tops of units, which represent an average altitude over a cell, were used to calculate a gridded thickness value for each model layer or hydrogeologic unit. These thickness values were then compared to the gridded thickness values derived from the published contours of unit thickness. The comparison of the gridded thickness data and subsequent manual editing of both gridded thickness and structure contour values allowed for consistency between the two data sets. The resulting gridded data sets were thus consistent with each other and preserved, as much as possible, a good representation of the average values over a cell of the original data. Because structure contours and land-surface altitude change as much as $1,200 \mathrm{ft}$ over a cell and one-half of the contour interval (assumed accuracy) of the published data is about $100 \mathrm{ft}$, it was difficult to have both data sets consistent with each other and with the published maps. Therefore, there may be some inconsistencies between the gridded and published contours of thickness, but these inconsistencies were the minimum needed to preserve structure contours of tops, land-surface-altitude, and thickness of all units in both a stack and a layer of cells. However, the gridded values are believed to be the best representation of average values (tops and thickness) for all units. Last, the relatively small thicknesses of the confining units (generally less than one-half the contour interval of the thicknesses of the hydrogeologic units and much less than the total basalt unit thickness) indicate that the terminology of layers and units can be used interchangably.

The Grande Ronde Basalt underlies virtually all of the area and constitutes 85 to 88 percent of the volume of the Columbia River Basalt Group (Reidel, 1982; Tolan and others, 1987). It crops out mainly along the northern, southeastern, and southern margins and in a few deeply incised stream channels in the central part of the plateau. Its thickness varies from a few feet along the northern and southern margins, where it pinches out against "basement" rocks, to greater than 14,000 ft in the central and southwestern parts of the study area (Drost and others, 1990). The Grande Ronde Basalt is composed of as many as 130 individual flows (Tolan and others, 1987). Most Grande Ronde Basalt flows are fine grained with microphenocrysts of plagioclase and clinopyroxene. Sedimentary interbeds in the Grande Ronde Basalt are rare, generally only a few feet thick, and of small lateral extent owing to the size of successive flows and the short time intervals between them. A sedimentary interbed between the Grande Ronde Basalt and the overlying Wanapum Basalt occurs in much of the area. Owing to different sedimentary formations occupying this stratigraphic position, nomenclature problems are avoided in this study by identifying interbeds according to their stratigraphic position within the basalt. Thus, this interbed is called the Wanapum-Grande Ronde interbed. Where present, this interbed is as much as $100 \mathrm{ft}$ thick and averages about $25 \mathrm{ft}$ (Drost and others, 1990). It consists chiefly of claystone and siltstone.

A thickness map of the Grande Ronde unit (plate 1c) was constructed for the modeling framework in order to estimate transmissivity values for the Grande Ronde unit. The thickness map was defined by first constructing a structure contour map of the top of the basement materials. Though this surface was in all probability irregular, it was assumed to be fairly uniform. This simplifying assumption was thought to be more appropriate than estimating the prebasalt topography. The structure contours were constructed on the basis of the elevation of outcrops and the bottom altitude of the basalts obtained from wells that penetrated the complete thickness of the basalts. The thickness distribution then was calculated by subtracting this surface from the top of the Grande Ronde Basalt structure contour or the land-surface altitude where the Grande Ronde Basalt crops out. Final adjustments were based on partially penetrating deep well information, magnetotelluric data (S.M. Baker, Rockwell International, written commun., 1984), sharp changes in the computed thickness over small distances, and estimates of the shape and extent of the basement rock. The calculated thickness varies smoothly throughout most of the plateau except in the Blue Mountains subprovince. The erosional features in the Blue Mountains, represented by land surface, gave a more variable thickness. 
The Wanapum Basalt crops out or is covered by a veneer of sediments throughout most of the northern half of the area (plate 1a). In the southern half, it is covered by either thick sequences of sediments or the Saddle Mountains Basalt. The Wanapum unit averages about $600 \mathrm{ft}$ in thickness, varying from a few feet where it pinches out against exposures of the Grande Ronde Basalt to more than 1,200 ft in the southwestern part of the area (Drost and Whiteman, 1986; Drost and others, 1990). The average thickness of the Wanapum unit and Wanapum-Grande Ronde interbed is presented on plate 1d. The Wanapum Basalt generally contains about 33 flows (Tolan and others, 1987) and makes up about 6 percent of the volume of the basalts. Most Wanapum Basalt flows are medium grained and slightly to moderately plagioclase-phyric. Sedimentary interbeds are more common in the Wanapum Basalt than in the Grande Ronde Basalt, but are relatively rare and only a few feet thick. A sedimentary interbed between the Wanapum Basalt and the overlying Saddle Mountains Basalt occurs in part of the study area and is called the Saddle Mountains-Wanapum interbed. This interbed is as much as $200 \mathrm{ft}$ thick and averages about $50 \mathrm{ft}$ (Drost and others, 1990). The interbed consists chiefly of clay, silt, claystone, or siltstone, but does contain sand and conglomerate.

The Saddle Mountains Basalt underlies only the southwestern part of the area (plate 1a). The Saddle Mountains unit has a maximum thickness of more than $800 \mathrm{ft}$ and averages about $600 \mathrm{ft}$ (Drost and Whiteman, 1986; Gonthier, 1990; Drost and others, 1990). The average thickness of the Saddle Mountains unit and the Saddle Mountains-Wanapum interbed is presented on plate 1e. Individual flows in the Saddle Mountains Basalt vary greatly in texture and composition. Sedimentary interbeds are common and relatively thick, many being $50 \mathrm{ft}$ or more. The intercalated Beverly Member of the Ellensburg Formation is areally extensive and stratigraphically and hydrologically important in south-central Oregon and in parts of the Yakima Fold Belt.

Interbed sediments are derived from erosion of older rocks surrounding the plateau, from erupting volcanoes in the Cascade Range, and from the basalt itself. The areal extent, thickness, and lithology of interbeds depends on the time of exposure of a flow top before subsequent eruptions, duration of a Cascade volcanic event, proximity to an older rock source, and proximity to a stream. Grain size varies from gravel to clay. Generally, more sediment deposition accumulated in structural lows.

\section{Overburden}

The term overburden includes all materials thicker than $50 \mathrm{ft}$ and overlying the Columbia River Basalt Group that are important sources of ground water. Included are Pliocene to Holocene fluvial, glaciofluvial, eolian, and volcaniclastic sediments. The areal extent and thickness of the overburden, where saturated, are shown on plate if. The thickness ranges from 0 to $1,200 \mathrm{ft}$, with the thickest deposits occurring in structural basins and in areas adjacent to the Cascade Range (Drost and others, 1990).

A windblown silt, called loess, occurs throughout much of the Columbia Plateau. It reaches its greatest thickness and continuity in the Palouse subprovince of southeastern Washington, where locally it is as much as $250 \mathrm{ft}$ thick. Wind action and loess deposition were probably greatest during the Pleistocene, with glacial drift providing a major source of silt.

Another important source of silt was the Ringold Formation in the central part of the plateau in the Quincy, Walla Walla, and Pasco basins (Newcomb, 1958). This formation is of fluvial origin but contains some lacustrine materials and is at least $600 \mathrm{ft}$ thick. The Ringold Formation generally comprises three to four principal lithofacies, although this varies from one locality to the next (Tanaka and others, 1974; Myers and Price, 1981).

\section{Structural Features}

Drost and Whiteman (1986), Gonthier (1990), and Drost and others (1990) describe the geologic structures of the Columbia Plateau. The major structural features are best described relative to the subprovince they reside in. The Yakima Fold Belt subprovince has long, narrow faulted anticlines with intervening narrow to broad synclines 
that trend in an easterly to southeasterly direction from the western margin of the plateau to its center. The anticlines are generally asymmetrical, with the steepest limb to the north. Most major faults are thrust or reverse faults with strikes similar to the anticlinal fold axes; the faults probably are contemporaneous with the folding. Northwest- to north-trending shear zones and minor folds commonly transect the major folds.

The Palouse subprovince contains basalt flows with a regional dip to the southwest of less than 5 degrees. This subprovince is structurally simple, and the largest features are broad folds with amplitudes of only a few tens of feet.

The Blue Mountains are a broad anticline extending from north-central Oregon into southeastern Washington. The anticline is cut by a series of north- to northwest-trending faults that are nearly vertical. The basement or core of the anticline is composed of folded, faulted, and metamorphosed upper Paleozoic and Mesozoic rocks.

\section{Conceptual Model For Ground-Water Movement and Numerical Simulation}

The geologic and hydrologic characteristics of the rock materials underlying the Columbia Plateau are varied and complex. In order to examine ground-water occurrence, movement, and water quality within such a complex system, it has been necessary to simplify the geologic and hydrologic frameworks. This simplified system provides the basis for numerical modeling and describing the ground-water flow in the regional aquifer system.

Ground-water movement is affected by the areal distribution of natural recharge and discharge, the geometry of the basalts and overburden, the spatial distribution of hydraulic conductivity, recharge from water-management practices, and prolonged irrigation pumping. The dominant pattern of ground-water movement is from areas of higher land-surface elevations toward the major surface-drainage features. Variations in flow direction within the aquifer system generally are affected by the depth of burial. The occurrence, extent, and composition of interbeds, the degree of confinement and occurrence of the ground water, and the permeability are all related to depth of burial.

Ground water in the basalts occurs in joints, vesicles, fractures, other local features that create permeable zones, and in intergranular pores of the sedimentary interbeds. High permeabilities generally occur in flow tops, in vesicular zones at the base of colonnades, and in basal, pillow-palagonite complexes. The more dense and coherent entablature and most of the colonnade probably have low permeabilities. Sharp folding and faulting can cause shearing and fracturing of the basalt flows and create local areas with large permeability in joints and fractures, whereas shear faulting can offset the interflow zones and disrupt their hydraulic continuity. Displacement of individual flows along faults, however, locally can enhance vertical movement of water by providing fractured zones across basalt flows that could serve as conduits for vertical ground-water flow. Basalt permeability undoubtedly has improved in places where erosion has beveled and dissected basalt units. It appears that a combination of the permeability increases described above result in the highest primary permeabilities in the basalts. Local increases in the thickness of enclosed sediments results in an increase in the storage capacity of the system at that interval and also alters the permeability of the system. In some areas, sedimentary interbeds serve as aquifers where their lithologies facilitate the storage and transmission of water.

Previous studies of ground-water flow in the Columbia River basalts have suggested that certain structures affect ground-water movement. Newcomb (1961, 1965, and 1969) cites lateral flow impediments that cause linear zones of large hydraulic gradients at locations near Walla Walla, Wash., in the Cold Creek syncline east of Yakima, Wash., and southwest of The Dalles, Oreg. Those impediments are caused by faulting and sharp folding. F. A. Packard (U.S. Geological Survey, written commun., 1989) analyzed an area of the Horse Heaven Hills in which a linear ground-water impediment, probably associated with shear faulting, impedes ground-water movement toward the Columbia River. The impediment causes upward ground-water movement in an area where the regional flow is otherwise downward. Similarly, a study of the Umatilla area in Oregon (Davies-Smith and others, 1988) found that just upgradient (south) of the east-west-trending Willow Creek monocline (plate 1b) (ground-water flow is northward) the vertical flow gradient is upwards instead of the more usual downward gradient. In addition, along the monocline, the lateral hydraulic gradient is steeper than to either side. In parts of the Yakima Fold Belt, the inner sections of anticlines are exposed, for example, Umtanum Ridge (see plate 1b). As seen in the exposures, the 
basalt is "tight" with a conspicuous absence of the interflow zones that usually are evident in exposures of undeformed basalt flows. Thus, it can be expected that sharp folds and major faults affect ground-water flow in the basalts and are associated with linear zones of low hydraulic conductivity. Regional, or controlling, values of hydraulic conductivity are smaller in areas typified by extensive structural features (major and minor).

Ground water moves both laterally and vertically in the interflow zones, flow centers, and sedimentary deposits. Lateral hydraulic conductivities generally are assumed to be greatest in the interflow zones primarily because of features such as flow breccia, clinkers, and vesicles. Hydraulic conductivities in the flow centers are controlled by secondary features--the predominantly vertical joints and fractures of the entablature and colonnade. Consequently, the interflow zones support most of the lateral ground-water movement, whereas movement in the flow centers is mainly vertical. Therefore, the interflow zones in the basalt sequence (fig. 2) are numerous, thin, semiconfined aquifers whose physical and hydraulic characteristics vary laterally and vertically.

The lithology of sedimentary interbeds within a formation varies from shales to sand and gravels. Except for the Saddle Mountains Basalt, most interbeds within formations are of limited extent. The interbeds between formations are more extensive laterally, and are thin when compared with basalt formations. These interbeds are locally transmissive and function as aquifers, but in general they impede the vertical movement of water. Water-level and well-log data suggest that the interbeds are semiconfining to locally confining units that transmit small amounts of water laterally. Sparse hydrologic data exist for the interbeds. Therefore, in this study, their hydraulic characteristics are incorporated into the hydraulic characteristics of the basalt units.

The overburden in the topographic basins forms small to large water-table aquifers that have less variable hydraulic characteristics than the basalts. The overburden generally is coarse grained and highly permeable in its upper sections, and finer grained and less permeable at depth. Average hydraulic conductivity of the overburden is usually several orders of magnitude greater than that of the basalt. For this regional study, the overburden is considered a single unit and herein is referred to as the overburden aquifer.

To simulate ground-water movement with a numerical ground-water model, the aquifer system is discretized into blocks. Each block representing a part of the water-table aquifer has a vertical dimension (saturated thickness) that varies according to the water level. Each block representing a part of a confined or semiconfined aquifer has a fixed thickness unless the water level drops below the top of the aquifer, in which case it then has a water-leveldependent thickness. The blocks are assigned hydraulic characteristics representative of the contained aquifer materials. The discretization of the aquifer system gives either a three-dimensional or a layered two-dimensional (quasi-three-dimensional) model for numerical simulation. A fully three-dimensional numerical model of the ground-water flow requires that geometric, physical, and hydraulic characteristics be assembled for the entire thickness of the aquifer system--a task not possible with available data. Instead, a layered, two-dimensional representation was adopted.

To obtain a layered representation for basalts, the hydraulic heads for a set of basalt flows are integrated vertically. This process then is repeated for overlying and underlying sets for all the flows. The integrated heads represent several two-dimensional areal head distributions. Combining or super-positioning these distributions constitutes a layered, two-dimensional ground-water flow system that represents the areal and vertical distribution of head and the implied horizontal and vertical movement of water. Although regional thickness, structural, and hydrologic data are not available for individual basalt flows, they are available for groups of basalt flows composing the Saddle Mountains, Wanapum, and Grande Ronde Basalts. This constraint, and the potential hydrologic control by the sedimentary interbeds, led to representation of the basalt part of the aquifer system as three layers corresponding with the mapped geologic formations. Similarly, for lack of data, the overburden aquifer has been conceptualized as a single two-dimensional flow system with depth-integrated hydraulic heads and characteristics. This single-unit representation of the overburden aquifer is reasonable because the areal extent is much larger than its thickness, and vertical head changes are relatively small compared with the areal head changes. 
The Saddle Mountains-Wanapum and Wanapum-Grande Ronde interbeds are not included in the three basalt units and are considered confining units for the Columbia Plateau aquifer system. Because of their variable extent and lithology, they simply are called confining units and are not named. The prebasalt "basement" rocks are believed to have much smaller permeabilities than the basalts and are considered the base of the regional flow system. The basement rocks are called the basement confining unit.

Within each of the four aquifer units, ground-water flow is assumed to be horizontal, and vertical movement of water between units is mathematically represented through the use of a "leakage coefficient" or vertical conductance. This conductance, in effect, represents the limiting vertical hydraulic conductivity of any intervening interbeds and the half thickness of adjacent overlying and underlying rock materials. For any location, the hydraulic head of each unit is assumed to be the average over the entire thickness and is assumed to be equivalent to the head near the center of the unit.

The Grande Ronde unit was divided further into two layers for this study, the upper and lower Grande Ronde layers. The name Grande Ronde unit hereafter refers to both layers, and upper or lower will be used to describe the two layers within the Grande Ronde unit. The lower layer was defined as being present wherever the Grande Ronde unit is thicker than about 2,000 ft. Thus, the maximum thickness of the upper Grande Ronde is about $2,000 \mathrm{ft}$, and the thickness of the lower Grande Ronde ranges from about 100 to more than $10,000 \mathrm{ft}$. The Grande Ronde unit was divided for the following reasons: (1) no production wells penetrate more than about 2,000 ft of the Grande Ronde Basalt; (2) in areas where the Grande Ronde Basalt is at the surface, there is generally enough vertical head gradient to warrant separating the Grande Ronde unit into two parts; (3) data were lacking to describe the lower unit, including its thickness; (4) the division provides the ability in the future to update information on the deeply buried Grande Ronde Basalt; and (5) the division provides better definition of the flow system where water-management activities are greatest.

In summary, the conceptual model of the Columbia Plateau aquifer system consists of seven units and, for numerical simulation, consists of five, vertically connected, two-dimensional layers. The hydraulic head distribution, which can be described and simulated within this concept, constitutes a three-dimensional ground-water flow system. Vertical flow between layers can be determined from the difference in heads between layers and the vertical conductance values. Correlation between stratigraphic units, conceptual model, and model layers is shown in figure 3 , and presents the nomenclature for the Columbia Plateau aquifer system.

\section{Movement of Water}

Ground-water-level contour maps for the overburden aquifer and the three basalt units are found in Bauer and others (1985) and for the three basalt units in Whiteman (1986) and Lane and Whiteman (1989). A general discussion of movement of water based on the published information for 1983, 1984, and 1985 is presented below for the four study units. Maps of model-calculated water levels for each aquifer unit are presented on plate 12a-e. The model-calculated values are similar to the observed and give a good representation of the regional flow system. Additionally, a surficial water-level map (representing the water table for the complete aquifer system) is presented on plate 12f. More detailed discussions based on results of the ground-water model are covered in later sections.

\section{Basalt Units}

In most areas, water-table conditions exist in the uppermost basalt unit (plate 1a). Because of the great difference between horizontal and vertical hydraulic conductivities, the presence of sedimentary interbeds, and the presence of fine-grained materials in parts of the lower section of the overburden aquifer, the deeper basalt units are generally semiconfined. However, the hydraulic connection between units is sufficient to allow continuous vertical movement of water between them. Water-level data indicate that over most of the plateau the vertical component of 
flow is downward, except near discharge areas. Discharge areas generally are in topographic lows. Anomalies to this overall pattern are caused by geologic structures (some of uncertain nature), by ground-water pumpage, and by irrigation.

The potentiometric surface of the Saddle Mountains unit closely parallels the land surface in areas where little or no overburden is present, especially at higher altitudes. Ground water flows toward surface-drainage features. This pattern of flow is similar in the Wanapum and Grande Ronde units where they are not overlain by another unit. Flow in the deeply buried parts of the Wanapum and Grande Ronde units is less controlled by surfacedrainage features; water movement is controlled by vertical leakage. For example, in the Quincy basin (fig. 1), ground water within the Wanapum unit, which is at or near land surface, flows toward Moses Lake and Potholes Reservoir. Ground water in the underlying Grande Ronde unit, however, is relatively unaffected by these surface drains and flows south toward the Columbia River.

Within the Palouse subprovince, north of the Snake River, ground water in both the Wanapum and Grande Ronde units flows toward the southwest, and regional discharge is to the Columbia and Snake Rivers. Here, water levels closely parallel the land surface and the regional dip slope of the basalts. In the Yakima Fold Belt, ground water flows downward from the anticlinal ridges toward the streams and rivers in the intervening synclinal basins.

\section{Overburden Aquifer}

Ground-water flow in the overburden aquifer is similar to that in the outcrop areas of the basalts. Recharge is mainly from precipitation and from infiltration of applied irrigation water. Discharge is to rivers, lakes, drains and waterways, wells, and to the underlying basalt unit. Downward movement of water to the basalts is controlled by the vertical conductivity, unit thickness, and head differences between the units. In the Quincy basin, which is part of the Columbia Basin Irrigation Project (CBIP), (fig. 1), larger vertical head gradients are noted in areas where large thicknesses of clay-rich materials directly overlie the Wanapum Basalt (H. H. Bauer and E. L. Bolke, U.S. Geological Survey, written commun., 1984). Where this clay layer is thin or absent, the heads in the overburden aquifer and Wanapum unit are nearly identical. Also in the Quincy basin, heads rose rapidly in both the overburden aquifer and in the Wanapum unit (Tanaka and others, 1974) after the onset of surface-water irrigation. In the more deeply buried Grande Ronde unit, heads did not rise rapidly, indicating that flow between the overburden and the underlying basalt unit is much greater than between adjoining basalt units.

\section{Lateral Hydraulic Conductivity}

The lateral hydraulic conductivity $\left(K_{h}\right)$ values for each aquifer unit were estimated initially from specific-capacity data. The modified Theis equation (Theis, 1963) for nonleaky artesian aquifers (Ferris and others, 1962, p. 99) was used to estimate transmissivity values from the specific-capacity data. The transmissivity values then were divided by an open interval to calculate $\mathrm{K}_{\mathrm{h}}$. The following simplifying assumptions for basalt wells, most of which are uncased, were used to estimate the open interval.

1. In practice, individual basalt flows cannot be distinguished on the basis of drillers' lithologic descriptions. Therefore, all basalt flows are assumed to be equal to the reported average thickness of $110 \mathrm{ft}$ thick, the average thickness estimated by Drost and Whiteman (1986).

2. Largest transmissivity values for a basalt flow are in the interflow zone (fig. 2). Therefore, during a pumping test, the vertical leakage between interflows is assumed to be small so that only the interflow zones tapped by the well contribute to the calculated transmissivity. 
3. Drilling generally ceases when a sufficiently productive zone or zones is encountered. This generally would occur in an interflow zone. Therefore, it is assumed that the bottom of the open interval of any given well is finished in an interflow zone, whereas the top of the saturated part of the open interval lies randomly within a basalt flow.

Thus, all basalt wells are assumed to penetrate 'effectively' at least one entire basalt flow, and the effective open interval is $55 \mathrm{ft}$ (one half of the average thickness of a basalt flow) greater than the actual saturated open interval, but not less than $110 \mathrm{ft}$ (at least one basalt flow).

Calculated overburden $\mathrm{K}_{\mathrm{h}}$ values (fig. 4) range from about $2.3 \times 10^{-7}$ to $1.7 \mathrm{ft} / \mathrm{s}(0.02$ to $150,000 \mathrm{ft} / \mathrm{d})$ and have a median of about $2.78 \times 10^{-3} \mathrm{ft} / \mathrm{s}\left(240 \mathrm{ft} / \mathrm{d}\right.$ ). Calculated basalt $\mathrm{K}_{\mathrm{h}}$ values (fig. 5) range from about $5.8 \times 10^{-8} \mathrm{ft} / \mathrm{s}$ to $7.0 \times 10^{-2} \mathrm{ft} / \mathrm{s}(0.005$ to about $6,100 \mathrm{ft} / \mathrm{d})$ and have a median of about $5.9 \times 10^{-5} \mathrm{ft} / \mathrm{s}(5.1 \mathrm{ft} / \mathrm{d})$. Seventy-five percent of the conductivity values are less than about $3.0 \times 10^{-4} \mathrm{ft} / \mathrm{s}(26 \mathrm{ft} / \mathrm{d})$, and 25 percent are smaller than about $1.2 \times 10^{-5} \mathrm{ft} / \mathrm{s}$ $(1.05 \mathrm{ft} / \mathrm{d})$. The median conductivities for the Saddle Mountains, Wanapum, and Grande Ronde units are about $2.78 \times 10^{-5}, 6.0 \times 10^{-5}$, and $5.7 \times 10^{-5} \mathrm{ft} / \mathrm{s}(2.4,5.2$, and $4.9 \mathrm{ft} / \mathrm{d})$, respectively. The smaller median for the Saddle Mountains unit is attributed to the numerous intercalated fine-grained interbeds, which generally are lacking in the Wanapum and Grande Ronde units. The upper quartile values and the upper end of the frequency distribution (fig. 5) indicate that primary permeability is enhanced at some locations (resulting in the larger hydraulic conductivity values) and that some type of geologic structure or pillow-palagonite complexes, not the interflow zone, is responsible for large conductivity values, as discussed in the subsection "Water Movement". The large range in the data shows the heterogenous nature of the basalts.

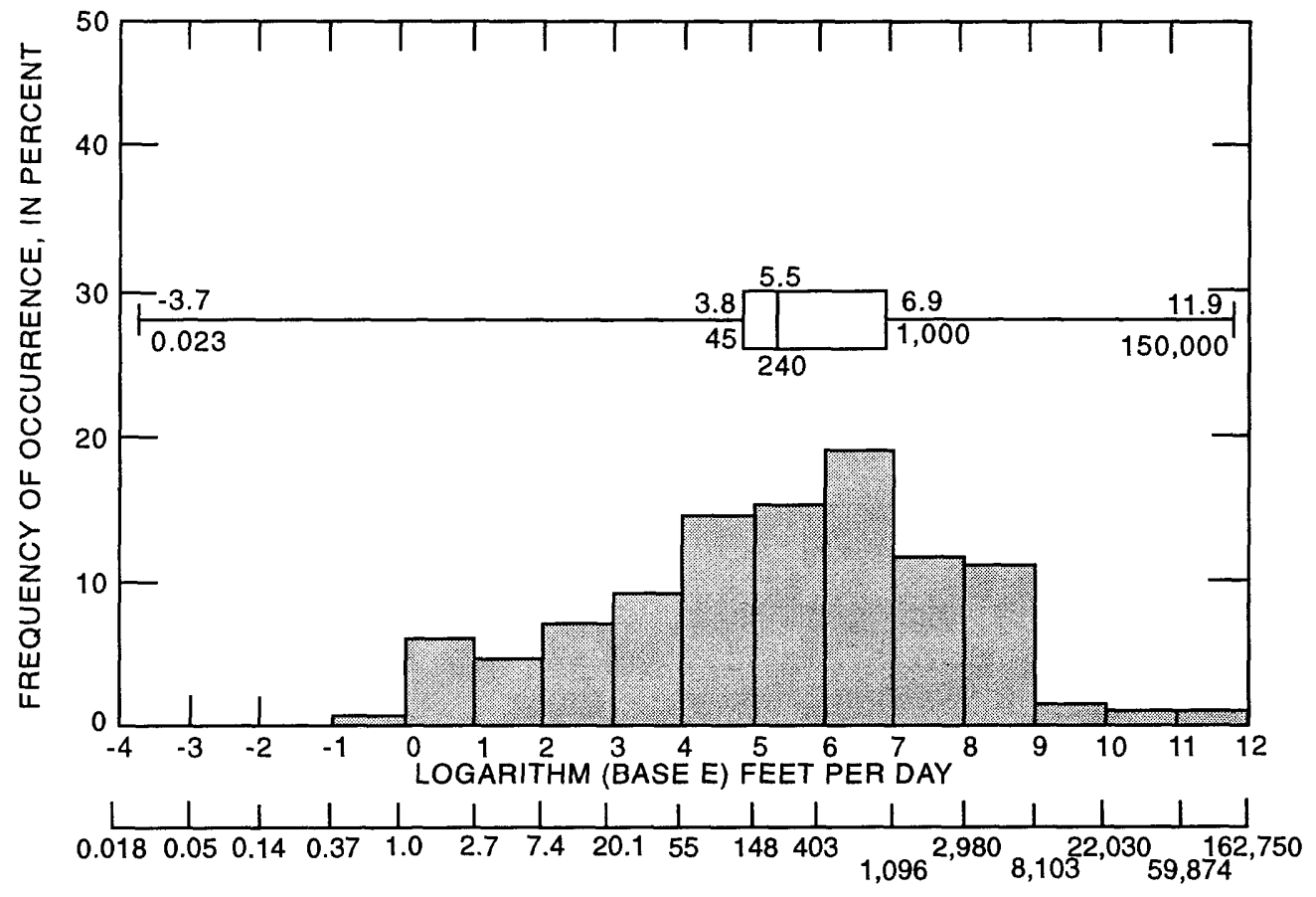

HYDRAULIC CONDUCTIVITY, IN FEET PER DAY EXPLANATION

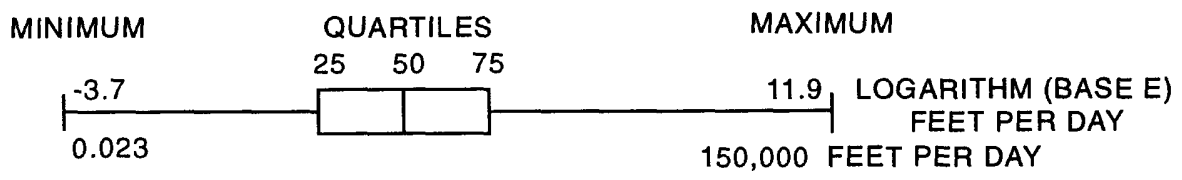

Figure 4.-- Frequency distribution of hydraulic-conductivity data for the overburden aquifer. 

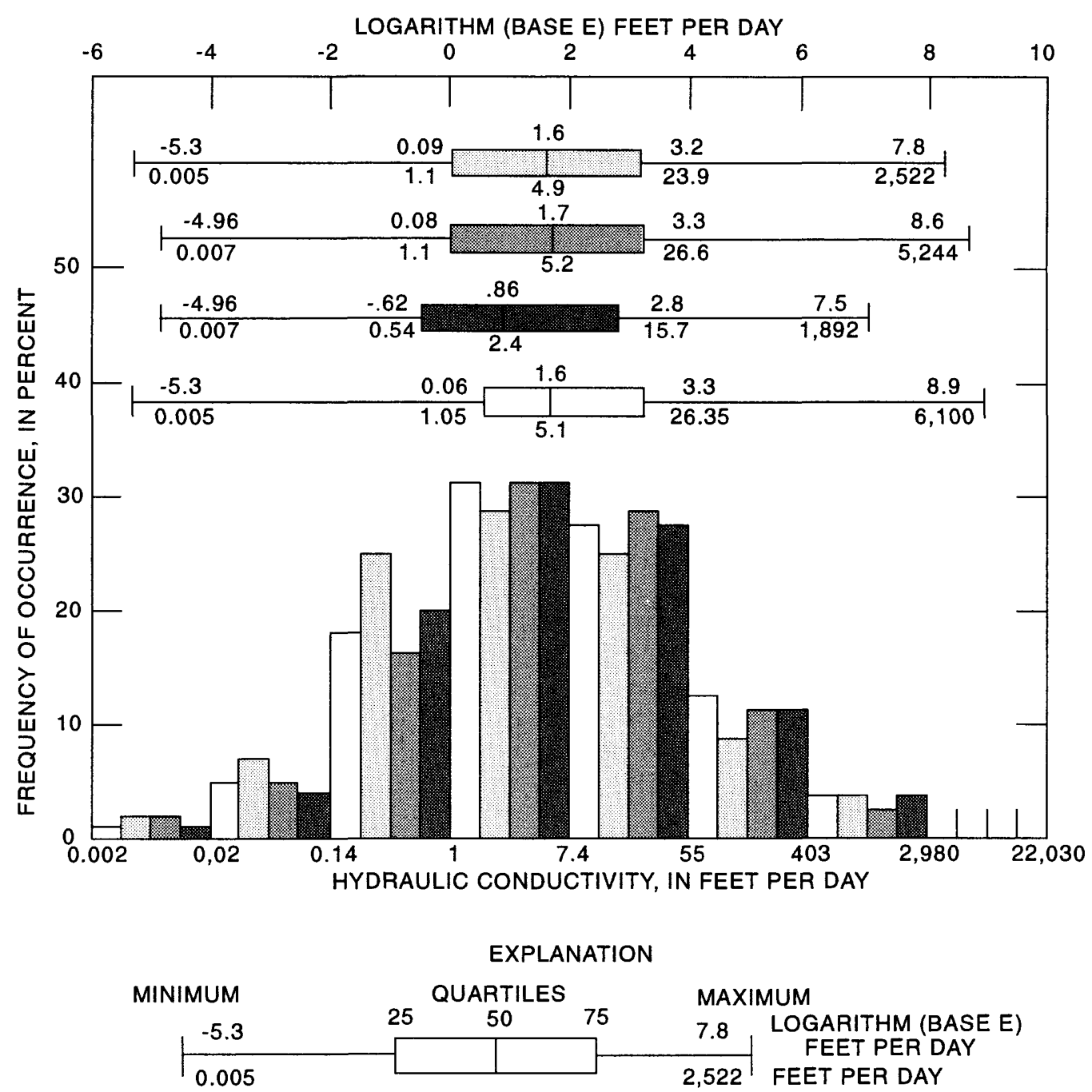

$\square$ All basalt units, estimated on the basis of 1,395 specific capacity tests

Grande Ronde unit, estimated on the basis of 446 specific capacity tests

2. Wanapum unit, estimated on the basis of 461 specific capacity tests

Saddle Mountains unit, estimated on the basis of 116 specific capacity tests

Figure 5.--Frequency distribution of hydraulic-conductivity data for the basalt units. 


\section{MODEL CONSTRUCTION}

\section{Description of Model}

The movement of ground water in the Columbia Plateau aquifer system was simulated using Hansen's (1993a) modified version of the three-dimensional, finite-difference ground-water flow model (MM) of McDonald and Harbaugh (1988). This model solves the following partial-differential equation:

$$
\frac{\partial}{\partial x}\left(K_{x x} \frac{\partial h}{\partial x}\right)+\frac{\partial}{\partial y}\left(K_{y y} \frac{\partial h}{\partial y}\right)+\frac{\partial}{\partial z}\left(K_{z z} \frac{\partial h}{\partial z}\right)-W=S_{s} \frac{\partial h}{\partial t}
$$

where, $\quad x, y, z$ are the cartesian coordinates,

$\mathrm{K}_{\mathrm{xx}}, \mathrm{K}_{\mathrm{yy}}, \mathrm{K}_{\mathrm{zz}}$ are the hydraulic conductivities in their respective coordinate directions ( $\mathrm{LT}^{-1}$ ),

$\mathrm{h}$ is the potentiometric head $(\mathrm{L})$,

$\mathrm{W}$ is a volumetric flux per unit volume and represents sources and sinks $\left(\mathrm{T}^{-1}\right)$,

$\mathrm{S}_{\mathrm{s}}$ is the specific storage of the porous material $\left(\mathrm{L}^{-1}\right)$, and

$\mathrm{t}$ is time $(\mathrm{T})$.

The finite-difference model requires discretizing the ground-water system into layers of rectangular blocks (cells) and specifying boundary conditions and initial head configuration for each layer. Values of variables also are specified for each active cell for each model layer.

The ground-water flow model simulations described in this report are for steady-state (predevelopment) and time-averaged conditions. These two conditions represent equilibrium predevelopment conditions and average hydrologic conditions for the period spring 1983 to spring 1985, respectively. Additionally, the predevelopment conditions are assumed to represent conditions in the 1850's, the latest representative period without water-development activities.

For the steady-state model, the right-hand side of equation 1a is zero (no head changes with time) and drops out. In this case, the hydraulic heads are assumed to represent a long-term average head under the estimated recharge for the predevelopment period. During this period, recharge is assumed to be equal to discharge. For the time-averaged model, equation 1 a is integrated with respect to time over the period of interest (spring 1983 to spring 1985), and all variables and stresses represent the average for that period. As a result of the time integration, equation 1a becomes:

$$
\frac{\partial}{\partial x}\left(K_{x x} \frac{\partial \bar{h}}{\partial x}\right)+\frac{\partial}{\partial y}\left(K_{y y} \frac{\partial \bar{h}}{\partial y}\right)+\frac{\partial}{\partial z}\left(K_{z z} \frac{\partial \bar{h}}{\partial z}\right)-\bar{W}_{t}=0
$$

with

$$
\overline{\mathrm{W}}_{\mathrm{t}}=\overline{\mathrm{W}}-\mathrm{S}_{\mathrm{s}} \frac{\Delta \mathrm{h}}{\Delta \mathrm{t}}
$$

where,

the overbars indicate time-averaged quantities,

$\Delta t$ is the length of the time-averaging period $(T)$,

$\Delta \mathrm{h}$ is the change in head over the time-averaging period of $\Delta \mathrm{t}(\mathrm{L})$, and all other variables are as previously defined.

Thus, the change-in-storage term now becomes a volumetric flux per unit volume, is added to the term $\overline{\mathrm{W}}$, and is equal to the change in water level over the time-averaging period, divided by the length of time for averaging and multiplied by an estimated storage coefficient. For any cell with head changes in a time-averaged simulation, the 
effect of water-level declines would be an inflow from storage that could be simulated by an equivalent increase in ground-water recharge or an injection well, and the effect of water-level rises would be an outflow to storage that could be simulated by an equivalent decrease in ground-water recharge or a withdrawal well. For implementation into the model, the time-averaged change-in-storage term is input injection wells and decreased recharge, discussed later in the "Change-in-Storage" section. The time-averaged equation, $1 \mathrm{~b}$, has the exact form as equation $1 \mathrm{a}$ under steady-state conditions; however, $\overline{\mathrm{h}}$ calculated by the model is the time-averaged head. It should be noted that the water-level contours for spring 1983, 1984, and 1985 of Bauer and others (1985), Whiteman (1986), and Lane and Whiteman (1989), respectively, showed barely discernable differences for the intervals of contours presented. This corresponds to the maximum water-level change of about $30 \mathrm{ft}$. Thus, the change-in-storage term is generally small for the time-averaged period. The time-averaging technique for ground-water flow simulation has been used by numerous investigations (Prych, 1983; Bolke and Vaccaro, 1981; Lum and others, 1990; Garabedian, 1986).

The ground-water model used the following modules of McDonald and Harbaugh (1988) in this study: block-centered flow, drain, river, general head boundary (GHB), well, and strongly implicit procedure (SIP). The drain module simulated leakage to irrigation drains, smaller lakes, and smaller streams (mostly ephemeral). The river module simulated leakage from or to major perennial streams and the large lakes. The GHB module simulated exterior seepage-face boundaries and interior seepage-face boundaries formed by either erosional activity or tectonic uplift. (Rivers, drains, and GHBs are thoroughly discussed later in the report in the "Parameters" section.) The well module simulated ground-water pumpage withdrawals and the time-averaged, volumetric change-in-storage flux. SIP was used for solution of the equations because testing showed it performed the best; that is, it was the most stable and fastest of the available iterative solvers. The recharge module did not estimate recharge, but was used to read in estimates that were computed independently by Bauer and Vaccaro (1990).

\section{Modifications to Model}

Hansen (1993a) modified the model of McDonald and Harbaugh (1988) for this study. The modifications allow the following three operations. (1) The branch conductance between two adjacent cells can be set to zero. This modification simulates the condition where a layer is cut completely through by a canyon and the next lower layer outcrops at the bottom of the canyon. (2) Lateral hydraulic conductance can be changed on one or more boundaries of an individual cell (a cell wall) to account for local, linear anisotropy such as faulting could produce. (3) The vertical flow part of the equations has been modified to simulate water in a cell flowing to an overlying or underlying cell, if the intervening layer(s) are absent (for example, pinchouts).

\section{Model Grid System}

The model grid is based on the 1983 and 1984 water-level configurations (Bauer and others, 1985; Whiteman, 1986), geology and geologic structure maps of the study area (Drost and Whiteman, 1986; Gonthier, 1990; Drost and others, 1990), the need for easily stated and tractable model boundary conditions, and facilitation of grid generation and model use. The extent of the Columbia River Basalt Group within the study area, and the modeled part of the basalts was shown previously in plate 1a.

A north-south oriented rectangular area that encompasses the hydrologic study area was defined first on a geographic-coordinate system based on latitude and longitude. Areas outside of the hydrologic study area (geohydrologic boundaries) are not considered part of the regional flow system; they comprise subregional or local flow systems. A rectangular grid system then was generated using 2.0-minute by 2.5 -minute latitude and longitude cells (averaging about $2.8 \mathrm{mi}$ in latitude and $1.5 \mathrm{mi}$ in longitude). The size of cells in each direction was determined by the size of the study area, available computer storage, data availability, and an estimate of the minimum block size that would still describe most of the geologic structures (F. A. Packard, U.S. Geological Survey, written commun., 1989). This resulted in 76 rows of latitude and 130 columns of longitude. 
The aquifer system then was divided into five layers (fig. 3). These layers, numbered from the youngest to the oldest, are:

\author{
Layer 1 Overburden aquifer \\ Layer 2 Saddle Mountains unit \\ Layer 3 Wanapum unit \\ Layer 4 Upper Grande Ronde \\ Layer 5 Lower Grande Ronde.
}

The external boundary for the Grande Ronde unit, layers 4 and 5, closely corresponds to its lateral extent for the eastern, northern, and part of the southern and western sides (plate 1a). A series of east-west-trending outcrops of the basement confining unit, the Blue Mountains anticline, and the Blue Mountains drainage divide represent part of the southern and southeastern boundary. In four other areas near the Snake, Klickitat, Grande Ronde, and Deschutes Rivers, the location of flow lines (determined from the water-level maps) and the geologic framework near the four rivers, all of which are incised deeply into the Grande Ronde Basalt, helped define the boundary. The boundary, in some areas, was extended to hydrologic divides beyond those four rivers in order to reach natural system (no flow) boundaries and to allow the rivers to be accurately represented on the simulations (not be a constant head). Layer 5, the lower Grande Ronde, extended to wherever the Grande Ronde unit is less than about $2,000 \mathrm{ft}$ thick. The upper Grande Ronde, layer 4, has 6,977 active cells and the lower Grande Ronde, layer 5, has 4,310 active cells.

The boundary for layer 3, the Wanapum unit, is the lateral extent of the hydrologically connected Wanapum Basalt in all but the northern part of the study area. In the northern part (from west to east), Banks Lake, the extent of the Wanapum Basalt, an east-west-trending anticline, and ground-water flow lines all were used to define the boundary. In Lincoln County, Wash., the Wanapum unit north and west of Banks Lake and Beezely Hills (fig. 1) was included with the upper Grande Ronde in layer 4; the Wanapum unit in this locality is generally discontinuous because of erosion. Further, thickness and water-level data indicate that the aquifer system in this area, in general, acts as one hydrogeologic unit. The Wanapum unit, layer 3 , consists of 4,414 active cells.

The boundaries for the Saddle Mountains unit, layer 2, approximate the lateral extent of the Saddle Mountains Basalt; this unit has 1,229 active cells. About 180 cells were unsaturated (set as inactive) in the predevelopment (steady-state) ground-water model.

The boundary of layer 1 , the overburden aquifer, is generally the $50-\mathrm{ft}$ thickness contour. However, some areas more than $50 \mathrm{ft}$ thick are unsaturated and were not included in the model. The overburden aquifer has 969 active model cells for the time-averaged simulation. Because many of these cells were unsaturated prior to water-management activities, active cells for layer 1 decreased to 624 for the predevelopment simulation.

The model grid systems for each layer, from youngest to oldest, are shown on plate 2 . The total number of active model cells for the time-averaged simulation, represented by the model grid system on plate 2 , is 17,899 . The vertical spacing for each layer, $\Delta \mathrm{z}$, represents the saturated thickness and is discussed later along with transmissivity values.

\title{
Boundary Conditions
}

At each lateral external boundary cell for each layer, a boundary condition is specified as a ground-water head, a specified flux, or a head-dependent node (a seepage-face boundary). Generally, the five layers have natural, external geohydrologic boundaries that are represented by no-flow (zero flux) or seepage-face boundaries (modeled as GHBs). Lateral internal boundary nodes, representing the geometry created by erosion, also use a 
head-dependent, GHB condition. The head-dependent value used in this study is the altitude of the layer bottom; thus, water can only discharge from the system. The GHB boundary condition is mathematically similar to a drain or river function, but when specified as a GHB, it identifies a cell as having a lateral boundary (unit truncated). The free-surface (water-table) boundary condition was a specified flux for this study. The specified flux is equal to the recharge and is assigned to the uppermost active model cell for each stack of layers. Although the recharge is a boundary condition, it is independently described later in the "Recharge" section.

In addition to lateral extent boundary conditions (no-flow and head-dependent seepage-face boundaries), the leakage of ground water to or from surface-water bodies is considered a boundary condition for purposes of discussion in this section. As discussed previously in the "Description of Model" section, the process of water moving to or from surface-water bodies (including farm drains) was simulated by using either the river or drain modules. Both of these modules, or conceptual models, simulate a head-dependent type of boundary condition (McDonald and Harbaugh, 1988, equations 63 and 69). Although the physical meaning of the terms, excluding the assigned head-dependent value, in equations 63 and 69 may differ, both equations essentially relate a head difference to a proportionality factor in order to calculate a flux of water; however, when using the drain module, ground water may only discharge to the modeled surface-water body. As described previously and later discussed in detail in the "Streams, Farm Drains, and Lake-Leakage Coefficients" sections, leakage to and from larger surface-water bodies was simulated using the river module, and leakage to small, generally ephemeral, surface-water bodies and to farm drains was simulated using the drain module. Conceptually, the assigned river cells can receive or supply water to the ground-water system and may be reasonably affected by ground-water pumping; whereas the assigned drain cells, excluding farm drains, generally represent streams in upland areas that are supported by ground water, are located in local flow systems, have relatively small flows, probably will not be largely affected by pumping, and lie well below the local water table. Additionally, water movement to farm drains is modeled with the drain module because they only receive water; the farm drains were installed to intercept rising water tables in order to prevent waterlogging. Thus, GHB cells represent ground-water discharge at seepage-face boundaries, river cells represent leakage to or from large streams or lakes, and drain cells represent leakage to small streams (lakes) in local flow systems and to farm drains.

The boundary conditions for the top four model layers are shown on plate 2; in layer 5, the lower Grande Ronde, lateral boundaries are all specified flux equal to 0.0 (no-flow boundary) and it always subcrops. The distribution of river, drain, and GHB cells also is shown on plate $8 \mathrm{a}, 8 \mathrm{~b}$, and $8 \mathrm{c}$, respectively.

\section{Hydrologic Stresses}

The important hydrologic stresses to the Columbia Plateau aquifer system are the leakage to and from the surface-water bodies, ground-water pumpage, recharge, and to a lesser extent, storage changes. The large streamflow, numerous impoundments, and regulation of the major rivers in the study area preclude actual determination of the amount of ground water discharging to the rivers, which in turn makes any analysis of ground-water recharge based on streamflow measurements tenuous. Thus, estimates of recharge were computed independently of the ground-water model, whereas discharge from the ground-water system, excluding pumpage, was estimated by use of the model. Therefore, only pumpage, recharge, and the change in storage are discussed and presented in the following subsections. These three stresses are three of the sources and sinks accounted for in the $" \overline{\mathrm{W}} "$ term in equations $1 \mathrm{a}$ and $\mathrm{lb}$. 


\section{Pumpage}

Ground-water pumpage for the time-averaged simulation is for the period spring 1983 to spring 1985 . The pumpage is the average for that period, and is mainly the irrigation pumpage during 1983 and 1984.

Estimates of ground-water pumpage for 1984 for the Oregon part of the Columbia Plateau are from Collins (1987), and for the Washington part of the plateau and a small part of Idaho are from Cline and Knadle (1990). About 3,500 high-capacity wells pumped about $1,144 \mathrm{ft}^{3} / \mathrm{s}$ or 828,300 acre- $\mathrm{ft} / \mathrm{yr}$ of ground water from the regional aquifer system in 1984. Irrigation use accounts for 85 to 90 percent of the total, and public supply and industrial uses account for the remainder. In 1984, ground water irrigated nearly one-half million acres of cropland. The quantity of ground water used for domestic purposes and other uses, such as stock watering, are too small to be considered in this regional analysis.

Pumpage estimates were made by one of three methods. First, pumpage data were available for the relatively few wells equipped with flowmeters. Second, using a relation between pumpage and power consumption for wells with power-consumption data but no flowmeter, pumpage was calculated. Last, using irrigated acreage data, crop type, and annual water-application rates for wells lacking either of the above data, pumpage was estimated. In Washington, data from published reports, field-site visits, population figures, remote sensing and Landsat scenes, water rights, an inventory of water suppliers, and well-site information on file in the office of the U.S. Geological Survey were used to estimate a time-averaged pumpage where more specific data were lacking. More detailed information on the methods of determining ground-water pumpage for 1984 is found in reports by Cline and Knadle (1990) and Collins (1987).

Similarly, Cline and Collins (1992) estimated pumpage for 1983 to be about $1,123 \mathrm{ft}^{3} / \mathrm{s}(813,300 \mathrm{acre}-\mathrm{ft} / \mathrm{yr})$ and used these values with the 1984 values to calculate an average pumpage for use in the time-averaged simulation. The time-averaged estimate of pumpage is $1,135 \mathrm{ft}^{3} / \mathrm{s}$ or about 822,000 acre-ft/yr. The areal distribution of this pumpage for layers 1 through 4 is shown on plate 3; there is no pumpage from layer 5 . For wells that tap more than one unit, pumpage was apportioned according to the amount of saturated thickness per unit open to the well. About 32 percent of the pumpage was from the Grande Ronde unit, 40 percent was from the Wanapum unit, 4 percent was from the Saddle Mountains unit, and 25 percent was from the overburden aquifer. The greatest pumpage occurred near Hermiston, Oreg., and in three areas in Washington--southwestern Lincoln and north-central Adams Counties (locally called and subsequently referred to as the Odessa-Lind pumping center), in the Quincy basin, and southern Franklin County.

\section{Recharge}

Bauer and Vaccaro (1990), using an energy-soil-water balance model (DPM) (Bauer and Vaccaro, 1987), estimated daily values of deep percolation below the effective root zone for 53 basins or zones underlain by the aquifer system. These daily estimates were used to calculate a long-term, time-averaged estimate of recharge for both predevelopment and current (1980's) land-use conditions. Bauer and Vaccaro (1990) used the 22-year period of record, 1956 to 1977, to estimate deep percolation for most of the basins or zones. This period exhibited good climatic variability. The predevelopment condition estimates were for input into the steady-state ground-water model, and the current condition estimates were for input into the time-averaged model. These inputs represent the free-surface specified-fluxes.

DPM computes deep percolation for a control volume (cv) that includes vegetation, if present, and soil down to the maximum prevalent root depth. If no vegetation is present, the cv extends to the total depth of the soil or to $5 \mathrm{ft}$, whichever is less. The root zone is divided into 6-inch layers, each with its own physical characteristics. The rectangular areas of the cv for 50 of the zones ranged from 0.25 to $1.0 \mathrm{mi}^{2}$, and the area of the cv for 3 zones was discretized with irregularly shaped quadrilaterals resulting in highly variable areas. The daily water budget for a cv is expressed as 


$$
P R C P=R O+E V I N T+E V S N W+E V S M+P T R+R E C H+\Delta I N T+\Delta S N W+\Delta S M
$$

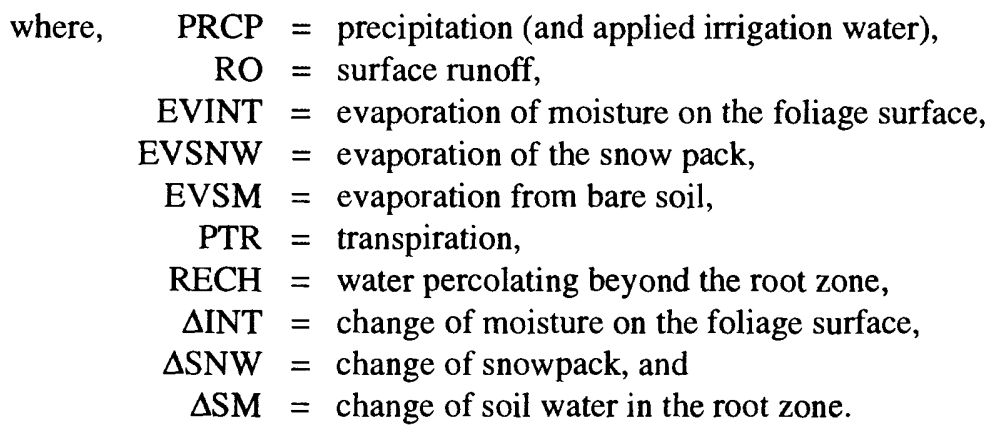

Data needed for each of the 53 modeled zones included daily streamflows, estimates of monthly baseflow, daily precipitation, and daily maximum and minimum air temperatures. Data needed for each cell of each model were: 22-year average-annual values of precipitation, mean monthly maximum and minimum air temperature lapse rates, soil-water-holding capacity, soil texture, topographic data (altitude-slope aspect), land-use classification, and annual irrigation application rates.

Bauer and Vaccaro (1990) describe and analyze in detail the following data used to estimate recharge in the 53 zones. The U.S. Department of Commerce (written commun., 1984) provided daily meteorological data for 103 weather sites, 89 of which had daily air-temperature data. Nelson (1991) developed an annual precipitation map for the period 1956 through 1977 (plate 4a). Bauer and Vaccaro (1990) regionalized mean monthly maximum and minimum air temperature lapse rates. U.S. Soil Conservation Service county soil maps provided soil-water-holding capacity and texture information. The multitude of different soil-type data were aggregated into 24 soil categories by similar physical characteristics. Altitude data were obtained from the U.S. Geological Survey as Digital Elevation Model (DEM) models (Elassal and Caruso, 1983), and slope and aspect for a cv were computed from these data. Land-use classification data initially were obtained from T. A. Zimmerman (Battelle Northwest Laboratory, written commun., 1984) and were based on the results of analysis of 1975 and 1979 Landsat data as described by Wukelic and others (1981). The land uses for the year 1975 were modified to account for increases in irrigated croplands based on information presented in Wukelic and others (1981) for 1979 and field and map identification of irrigated croplands by D. Cline, M. E. Knadle, and C. A. Collins (U.S. Geological Survey, written commun., 1986) for 1983 to 1985 . These current (1980's) land-use conditions represent a multiyear composite and are assumed to be representative of the time-averaged period of model simulation. Predevelopment land-use conditions were estimated from these data by assuming that dryland croplands were historically grasslands, irrigated croplands were historically sage, and residential/commercial/urban-type land use was historically sage. Surface-water-irrigation application rates were based on data given in the Washington State Department of Ecology (1974) and ground-water irrigation application rates were from D. R. Cline, M. E. Knadle, and C. A. Collins (U.S. Geological Survey, written commun., 1985).

The area-wcighted estimates of average recharge for each zone for predevelopment and current land-use conditions are shown on plate $4 \mathrm{~b}$. Recharge estimates for each $\mathrm{cv}$ of the 53 modeled zones were area-weighted and aggregated to the ground-water model cells encompassed by the 53 zones. Recharge was estimated using a polynomial regression equation for the area not covered by the modeled zones within the ground-water model boundaries. The regression relates the 22 -year average-annual precipitation to the calculated average recharge for all cv (about 30.000 data values) in the modeled zones. The 53 zones included most of the irrigated croplands and most of the area with annual precipitation less than $11 \mathrm{in} / \mathrm{yr}$. The average-annual precipitation values were interpolated to each cell of the ground-water model outside of the 53 zones using digitized values of the precipitation contours (plate 4a) and a surface-fitting routine described by IMSL (1982).

The distribution of estimated recharge within the ground-water model boundary for predevelopment and current land-use conditions is shown on plate $4 \mathrm{c}$ and $4 \mathrm{~d}$, respectively. These distributions differ from those of Bauer and Vaccaro (1990) in part of Oregon and in several areas along coulees in central Washington. This is 
because, during model calibration, certain zones appeared to have recharge estimates that were too small and, in certain areas, calculated head values were too small using reasonable hydraulic characteristics. Bauer and Vaccaro (1990) found that recharge estimates are most sensitive to total precipitation, soil type, and root depth of the predominant plant community. The larger surface area of the $\mathrm{cv}$ used in the three zones in Oregon (plate $4 \mathrm{~b}$ ) probably masked those three important physical properties, resulting in smaller estimated values of recharge. Also, the quantity of streamflow in the small ephemeral and perennial streams originating in those zones does not correlate well with the recharge, and the cv recharge from those zones does not fit as well into the developed regional regression relation compared to data from the other 50 zones. Therefore, the regression relation was used to estimate recharge for the ground-water model cells in those zones for both land-use conditions. For the cells in those zones with irrigated croplands, the regression equation could not be used. Recharge rates based on the mean annual precipitation and irrigation application rates for other zones with similar characteristics were assigned to those cells. Additionally, water levels simulated by the ground-water model were too low, resulting in cells being unsaturated in part of central Washington in the Odessa-Lind area. Only increases in recharge solved this problem. Measured peak flows for several of the coulees that traverse this area exceeded $1,000 \mathrm{ft}^{3} / \mathrm{s}$ in some years and there was little or no flow through of this water. This type of recharge pulse was not always accounted for by Bauer and Vaccaro (1990) because of lack of measurements. Thus, $0.95 \mathrm{in} / \mathrm{yr}$ of recharge was added to model cells with a large coulee. These line sources gave an additional $32 \mathrm{ft}^{3} / \mathrm{s}$ of recharge to the area. Additionally, about $9 \mathrm{ft}^{3} / \mathrm{s}$ were added to a recharge zone corresponding with an overestimate of surface runoff for that zone.

Estimated recharge for predevelopment conditions is about $6,570 \mathrm{ft}^{3} / \mathrm{s}(2.72 \mathrm{in} / \mathrm{yr})$, most of which probably discharged to surface-water bodies. The estimate of recharge for current conditions (1980's) is $10,210 \mathrm{ft}^{3} / \mathrm{s}$ ( $4.24 \mathrm{in} / \mathrm{yr})$. Thus, about $3,640 \mathrm{ft}^{3} / \mathrm{s}(1.51 \mathrm{in} / \mathrm{yr}$ ) of additional recharge was added, mainly because of irrigation.

\section{Change in Storage}

The time-averaged change-in-storage term represents a volumetric flux over the period spring 1983 to spring 1985. A value for this term is calculated for any model cell that had a decline in head during the time-averaging period. The calculated value for a cell is then input into the model as an injection well. Storage flow was not calculated for areas of water-level rises because water-level rises during the period of interest generally were due to increased recharge resulting from above-average precipitation. As explained previously in the "Description of Model" section, water-level rises would result in storage flows that could be simulated by an equivalent decrease in recharge. Investigation showed that the net recharge on these areas would be similar to the long-term natural recharge. Thus, long-term natural recharge was used on these areas rather than calculating the increased recharge from precipitation minus the equivalent recharge required to simulate flow to storage. The original water-level changes from spring 1983 to spring 1985 were mapped by Lane and Whiteman (1989) at a scale of 1:250,000. Mylar overlays of the grid system were overlayed on these original maps and the water-level changes were assigned to the appropriate model cells. Thus, the water-level changes (declines) mapped by Lane and Whiteman (1989) for each basalt unit (there were no observed water-level changes in the overburden aquifer) were assigned to the appropriate model cells, divided by the time period, and multiplied by an estimated storage coefficient of 0.04 . These calculated values were then input through the well module. As stated previously, the maximum water-level change was about $30 \mathrm{ft}$ and most of the changes were less than $10 \mathrm{ft}$. These water-level changes (and the seasonal water-level fluctuations) are much less than the interval for which the data was contoured and are much less than the thickness of the study units. The hydrologic budget for the time-averaged simulation, described later in the report, confirms that the change-in-storage term is a small component of the regional water budget. However, this term is later shown to be locally important.

\section{Calibration}

The following sections describe the calibration process, including a description of the parameter-estimation techniques and the calibration results for the time-averaged model. The calibration process is discussed in some detail because of the large size of the area modeled, the large number of active cells, the known variability of 
hydraulic characteristics, the complexity and influence of structural features, the numerous surface-water bodies and features (coulees), and variability in recharge estimates. There are about 28,800 values of hydraulic conductivities and vertical conductance parameters to estimate, and in addition, 5,812 parameters were estimated for the control of geologic structures and the GHB, river, and drain functions. The steps, and the order in which the steps were taken, show how the conceptual model of the flow system is used to arrive at a regionally calibrated model. The model always operated with the overburden aquifer as a water-table layer and the basalt units as layers fully convertible between water table and confined conditions.

An important factor that influenced model calibration is the lateral head gradient present within the aquifer system. Locally, the head changes laterally from about 5,000 to $400 \mathrm{ft}$ over about $40 \mathrm{mi}$, and there are extreme changes from about 4,500 to $800 \mathrm{ft}$ over $15 \mathrm{mi}$. This results in gradients ranging from 100 to $300 \mathrm{ft} / \mathrm{mi}(0.02$ to $0.06 \mathrm{ft} / \mathrm{ft}$ ) that the model needs to simulate. It is difficult to simulate those gradients in a regional model (cell dimensions are on the order of $2 \mathrm{mi}$ ). In a few areas, the observed gradients for some model cells were so large that no attempt was made to match them; model-calculated heads were assumed to be the best estimate of the vertically averaged head over a cell. Some of these cells had lateral and vertical head differences on the order of several hundred feet.

A comparison of lateral gradients in the Columbia Plateau aquifer system with gradients in other regional aquifer systems illustrates the large gradients on the plateau. Regional, hydraulic heads for the High Plains aquifer change from about 7,000 to 2,000 ft over about $365 \mathrm{mi}$ (about $14 \mathrm{ft} / \mathrm{mi}$ ) in the Northern High Plains and from about 5,000 to 3,000 ft over about $180 \mathrm{mi}$ (about $11 \mathrm{ft} / \mathrm{mi}$ ) in the Southern High Plains (Luckey and others, 1986). Regional heads for the Northern Great Plains aquifer system change from 3,900 to $1,500 \mathrm{ft}$ over about $280 \mathrm{mi}$ (about $9 \mathrm{ft} / \mathrm{mi}$ ) in the Madison aquifer and from 5,000 to 2,600 ft over about $240 \mathrm{mi}(10 \mathrm{ft} / \mathrm{mi})$ in the Pennsylvanian aquifer (Downey, 1986). Last, lateral head gradients in the Floridan aquifer system range from $0.25 \mathrm{ft} / \mathrm{mi}$ to $11 \mathrm{ft} / \mathrm{mi}$ (Bush and Johnston, 1988). Thus, the maximum gradients on the plateau are from 7 to 1,200 times as large as those in other regional aquifer systems.

The discussion that follows on calibrating (adjusting) the model parameters identifies the steps taken during the process and, conceptually, the relation of the adjustments to the hydrologic system. During the calibration process, pumpage was not altered. As described previously, the initial estimates of recharge were modified along coulees in the central part of the plateau and in some parts of Oregon. However, these modifications were based on either streamflow records or the initial recharge estimates in other areas. After those changes were made, the recharge was held constant (recharge was not considered a calibration parameter). It should also be noted that although not always explicitly discussed in the following sections, the differences between observed and calculated water levels and discharges were a major calibration criterion, and the known range in observed or previously estimated hydraulic conductivities was always accounted for.

\section{Parameters}

The generalized two-step technique used to estimate parameters was (1) initial coarse adjustment of parameters so that calculated and hand-drawn water-level contours in selected areas for steady-state conditions approximated each other, and the solution closure was reasonable, and (2) the time-averaged model was calibrated by adjustment of parameters and properties. Step 1 took about 5 percent of the calibration effort and step 2, the remainder. Step I was oriented mainly to estimating initial hydraulic and numerical parameters in order to have the model operate. The calibrated time-averaged model then was operated under the steady-state conditions. It was assumed that the parameters estimated with the time-averaged model were best estimates for simulating the flow in the predevelopment aquifer system.

Methods for initial estimates of hydraulic parameters were reevaluated during model calibration. However, either the initial or the final methods used might be appropriate for other aquifer systems. Thus, the calibration procedures for each of the hydraulic parameters, including the mathematical representations when appropriate, are described below for each parameter. Additionally, the descriptions of the calibration procedures allow for a more realistic assessment by other investigators of the final calibrated model. 


\section{Lateral hydraulic conductivity}

Overburden aquifer--Lateral hydraulic conductivity $\left(\mathrm{K}_{\mathrm{h}}\right)$ calculated from specific-capacity data was supplemented with values reported in previous studies (H. Bauer, U.S. Geological Survey, written commun., 1984; E. A. Prych, 1983; Bolke and Skrivan, 1981; Tanaka and others, 1974; Barker and McNish, 1976) and with values calculated by Drost (U.S. Geological Survey, written commun., 1987). $K_{h}$ was interpolated to the model grid cells. The maximum distance for interpolation was $25 \mathrm{mi}$ surrounding the center of a cell. If no values were within $25 \mathrm{mi}$, the median of the specific-capacity data was assigned (no values were interpolated). The means and the frequency distributions of the gridded values were similar to the $\mathrm{K}_{\mathrm{h}}$, and, as would be expected, the variance of the gridded values was smaller.

Using the initial gridded $\mathrm{K}_{\mathrm{h}}$, the model-calculated heads were much lower than observed heads. Therefore, $\mathrm{K}_{\mathrm{h}}$ was reinterpolated on the basis of the assumptions: (1) most of the specific-capacity data were from the more productive wells finished in the coarser materials (little data from the tighter sediments), and (2) tighter sediments control the movement of ground water. As a result, the maximum distance was reduced to $5 \mathrm{mi}$, the 35 th percentile (instead of the median) was assigned as the default value, and interpolated values larger than the median were set equal to the median. Subsequent model simulations improved the calculated head distribution.

During the final model calibration, these values were changed only slightly. Most of the changes occurred in $\mathrm{K}_{\mathrm{h}}$ for areas where there were little or no data and where the 35 th percentile was assigned. These areas typically consist of loess-type sediments with much smaller $\mathrm{K}_{\mathrm{h}}$ than the values initially assigned. Some descriptive statistics for the final model cell values for the overburden layer are listed in table 1. Values in table $1 \mathrm{can}$ be compared to the point data calculated from specific-capacity information (fig. 4) and to values presented in table 1 . The model-derived distribution of lateral hydraulic conductivity for the overburden aquifer is shown on plate $5 \mathrm{a}$.

Table 1.--Descriptive statistics of lateral hydraulic conductivity for the model layers

\begin{tabular}{|c|c|c|c|c|c|}
\hline \multirow[b]{6}{*}{ Statistics } & \multicolumn{5}{|c|}{ Layer number } \\
\hline & \multirow[t]{2}{*}{1} & \multirow[t]{2}{*}{2} & \multirow{2}{*}{$\begin{array}{c}3 \\
\text { Unit name } \\
\end{array}$} & \multirow[t]{2}{*}{4} & \multirow[t]{2}{*}{5} \\
\hline & & & & & \\
\hline & Overburden & Saddle & & Lower & Upper \\
\hline & aquifer & Mountains unit & Wanapum unit & Grande Ronde & Grande Ronde \\
\hline & & $\begin{array}{r}\text { Hydr } \\
\text { (Values in pa }\end{array}$ & $\begin{array}{l}\text { nductivity, in fee } \\
\text { es derived from }\end{array}$ & $\begin{array}{l}\text { ond } \\
\text { apacity data) }\end{array}$ & \\
\hline \multirow[t]{2}{*}{ Mean } & $1.14 \times 10^{-3}$ & $1.48 \times 10^{-5}$ & $3.73 \times 10^{-5}$ & $2.30 \times 10^{-5}$ & $2.62 \times 10^{-5}$ \\
\hline & $\left(9.53 \times 10^{-2}\right)$ & $\left(6.48 \times 10^{-4}\right)$ & $\left(7.60 \times 10^{-4}\right)$ & $\left(5.77 \times 10^{-4}\right)$ & \\
\hline \multirow[t]{2}{*}{ Minimum } & $4.98 \times 10^{-7}$ & $.197 \times 10^{-5}$ & $.101 \times 10^{-5}$ & $.110 \times 10^{-5}$ & $.150 \times 10^{-5}$ \\
\hline & $\left(2.86 \times 10^{-7}\right)$ & $\left(8.12 \times 10^{-8}\right)$ & $\left(8.12 \times 10^{-8}\right)$ & $\left(5.78 \times 10^{-8}\right)$ & \\
\hline \multirow[t]{2}{*}{ Maximum } & $12.7 \times 10^{-3}$ & $3.01 \times 10^{-5}$ & $9.03 \times 10^{-5}$ & $7.44 \times 10^{-5}$ & $9.98 \times 10^{-5}$ \\
\hline & $\left(1.73 \times 10^{0}\right)$ & $\left(2.19 \times 10^{-2}\right)$ & $\left(6.07 \times 10^{-2}\right)$ & $\left(2.92 \times 10^{-2}\right)$ & \\
\hline \multicolumn{6}{|l|}{ Deciles } \\
\hline 10 & $1.01 \times 10^{-5}$ & $.301 \times 10^{-5}$ & $.799 \times 10^{-5}$ & $.287 \times 10^{-5}$ & $.405 \times 10^{-5}$ \\
\hline 20 & $1.01 \times 10^{-5}$ & $.694 \times 10^{-5}$ & $1.62 \times 10^{-5}$ & $.357 \times 10^{-5}$ & $.405 \times 10^{-5}$ \\
\hline 30 & $1.01 \times 10^{-4}$ & $1.01 \times 10^{-5}$ & $1.92 \times 10^{-5}$ & $.693 \times 10^{-5}$ & $.799 \times 10^{-5}$ \\
\hline 40 & $1.97 \times 10^{-4}$ & $1.39 \times 10^{-5}$ & $2.55 \times 10^{-5}$ & $.854 \times 10^{-5}$ & $.922 \times 10^{-5}$ \\
\hline 50 & $4.98 \times 10^{-4}$ & $1.62 \times 10^{-5}$ & $3.01 \times 10^{-5}$ & $1.45 \times 10^{-5}$ & $1.61 \times 10^{-5}$ \\
\hline 60 & $7.92 \times 10^{-4}$ & $1.82 \times 10^{-5}$ & $3.01 \times 10^{-5}$ & $2.08 \times 10^{-5}$ & $2.20 \times 10^{-5}$ \\
\hline 70 & $1.01 \times 10^{-3}$ & $1.97 \times 10^{-5}$ & $4.55 \times 10^{-5}$ & $2.39 \times 10^{-5}$ & $2.55 \times 10^{-5}$ \\
\hline 80 & $1.78 \times 10^{-3}$ & $1.97 \times 10^{-5}$ & $6.02 \times 10^{-5}$ & $4.09 \times 10^{-5}$ & $4.42 \times 10^{-5}$ \\
\hline 90 & $2.31 \times 10^{-3}$ & $2.43 \times 10^{-5}$ & $8.99 \times 10^{-5}$ & $6.50 \times 10^{-5}$ & $7.99 \times 10^{-5}$ \\
\hline Number of cells & 969 & 1,229 & 4,414 & 4,310 & 6,977 \\
\hline
\end{tabular}


Basalt units.--Initial $\mathrm{K}_{\mathrm{h}}$ for the basalt units was interpolated in the manner as for the overburden aquifer. Additionally, each lower Grande Ronde cell was assigned a $\mathrm{K}_{\mathrm{h}}$ equal to 0.9 times the value of the overlying upper Grande Ronde cell. The lower density of data and wider range of conductivities probably introduce greater error into interpolated $\mathrm{K}_{\mathrm{h}}$ for the basalt units than for the overburden aquifer.

The initial basalt $K_{h}$ was adjusted for geologic structure on the Columbia Plateau. Areas of intense folding and faulting usually are typified by steep mountains and ridges (generally anticlines) where few wells have been drilled. Therefore, other than from outcrop inspection, little is known of the hydraulic characteristics in these areas. Water-level data in areas adjacent to these structural features suggest that $\mathrm{K}_{h}$ is, in general, smaller than surrounding conductivities. For example, Frenchman Hills, a relatively low-lying anticlinal ridge located just south of the Quincy basin and just north of the Royal Slope agricultural area (fig. 1), appears to separate the Wanapum unit hydraulically in these two areas. Just to the north of Frenchman Hills, water-level contours for the Wanapum unit have a small gradient and ground water flows generally to the east. Just south of Frenchman Hills, where water levels are lower, the gradient is large and flow is to the south. If $K_{h}$ was not reduced under Frenchman Hills, ground water would flow southward from the Quincy basin to the Royal Slope. Reduced $K_{h}$ for anticlinal ridges occurs wherever sufficient water-level data permit this type of analysis.

To account for the reduced $K_{h}$ for structural features, such as Frenchman Hills, a numeric code was assigned to basalt cells that represents a specific structure assigned to a cell. Each code, in turn, was assigned a multiplying factor less than or equal to $1 . \mathrm{K}_{\mathrm{h}}$ was multiplied by the structure cell factor. Some model cells with structure were reduced more than others because the factor varied by type of structure. For example, water-level data indicate that synclines and monoclines have a smaller effect on ground-water movement than do anticlines and faults. Thus, the larger reductions were made for faults and anticlines rather than for monoclines. Because of adequate data near synclines, no reductions were made to those cells defined as synclines. Initial multiplying factors were estimated by grouping cell $\mathrm{K}_{\mathrm{h}}$ on the basis of structural type, and comparing the statistics of these groups with the statistics of groups obtained from a calibrated model in the Horse Heaven Hills (HHH) area of Washington and Oregon (see fig. 1; F. A. Packard, U.S. Geological Survey, written commun., 1986). The comparison showed that the initial median $\mathrm{K}_{\mathrm{h}}$ for anticlines, faults, and inferred faults/impediments was 0.0167 times the $\mathrm{HHH}$ model median $\mathrm{K}_{\mathrm{h}}$ for these structures; $\mathrm{K}_{\mathrm{h}}$ at other cells was comparable. Because there are several large monoclines within the modeled area and no similar features within $\mathrm{HHH}$, however, the $\mathrm{K}_{\mathrm{h}}$ for monocline cells was reduced by a factor of 0.10 .

Operation of the model with the initial $\mathrm{K}_{\mathrm{h}}$ values produced poor results. As a test, the model was operated with a median $\mathrm{K}_{\mathrm{h}}$ for each layer except for the structure cells, which were multiplied by 0.0167 and 0.10 . The model would not operate with this distribution, indicating that the initial $\mathrm{K}_{\mathrm{h}}$ distribution was a better estimate than the median. The larger values in the initial distribution then were reduced. This concept then was applied to discrete areas within the model, except that both the top and bottom ends of the frequency distribution of basalt $\mathrm{K}_{\mathrm{h}}$ of the model-input were reduced and increased, respectively. Using these smaller $\mathrm{K}_{h}$ values, the model calculated reasonable distributions of lateral hydraulic head gradient but not head values. Therefore, hand editing--smoothing of the $K_{h}$ values for the basalt layers--was completed. These relatively smooth distributions were used for many model simulations.

Distributions of $\mathrm{K}_{\mathrm{h}}$ were changed later after analyzing hydrologic and model parameters and the conceptual model of flow. The analyses provided better understanding of the aquifer system. On the basis of this improved understanding, the point data were interpolated with a smaller, 2-mile, interpolation radius. Where no data existed, the 35 th-percentile $K_{h}$ value for each layer was used. Additionally, any interpolated values larger than the median were set equal to the median. Basalt $\mathrm{K}_{\mathrm{h}}$ within the Yakima Fold Belt, but outside of the synclinal areas, was set to the 20th-percentile value. Most of the broad, flat-lying area of the central plateau (within the Palouse subprovince) was assigned a $K_{h}$ equal to the 40 th percentile of the point data for the respective layer. The $K_{h}$ 's for the structurally affected southern edge of the modeled area in Oregon, where the Grande Ronde unit outcrops, were set to the 25 th percentile. 
The analyses also showed that initial $K_{h}$ assigned to the lower Grande Ronde was probably too large. Therefore, under the assumptions that (1) the overburden pressure for layer 5 would reduce hydraulic conductivity, and (2) more void space would be filled by secondary minerals, $K_{h}$ of layer 5 was reduced. The reduction was assumed to follow the equations of Weiss (1982),

$$
\begin{aligned}
& \text { change }=1 .-0.2((\mathrm{~B}+0.5 \mathrm{~b}) / 1,500), \mathrm{B} \leq 1,500 \mathrm{ft} \\
& \text { change }=0.8-0.1((\mathrm{~B}+0.5 \mathrm{~b}-1,500) / 1,500 .), 1,501 \mathrm{ft} \leq \mathrm{B} \leq 3,000 \mathrm{ft} \\
& \text { change }=0.7-0.2((\mathrm{~B}+0.5 \mathrm{~b}-3,000) / 9,000 .), 3,001 \mathrm{ft} \leq \mathrm{B} \leq 12,000 \mathrm{ft} \\
& \text { change }=0.45, \mathrm{~B}>12,000 \mathrm{ft}
\end{aligned}
$$

where, change $=$ the factor by which lateral hydraulic conductivity for layer 4 is multiplied in order to obtain values for layer $5\left(\mathrm{~L}^{0}\right)$,

$B=$ the cell thickness of all active layers above a layer 5 cell $(\mathrm{L})$, and

$\mathrm{b}=$ the cell thickness of layer $5(\mathrm{~L})$.

To simplify equation 3 , it was assumed that the reduction in conductivity with depth for any layer would follow a parabolic expression:

$$
\text { change }=1 .-(2 \sqrt{\mathrm{a}}) \sqrt{\mathrm{z}}
$$

where $\mathrm{z}$ is the depth to the midpoint of a layer and $2 \sqrt{\mathrm{a}}$ (the square root of the latus rectum) $=5 \times 10^{-3}$. The following is a comparison of values calculated with equation 4 and with equation 3.

\begin{tabular}{ccc} 
Depth (ft) & Equation 3 & Equation 4 \\
\hline 1,500 & 0.8 & 0.81 \\
3,000 & .7 & .73 \\
7,500 & .6 & .57 \\
12,000 & .5 & .45 \\
16,000 & .45 & .37 \\
20,000 & .45 & .29
\end{tabular}

The ratio of change values for layers 4 and 5 were used as the multiplying factors to define the hydraulic conductivity of layer 5 from that of layer 4 .

Using the new $\mathrm{K}_{\mathrm{h}}$ estimates, the model-simulated heads were too high in many locations. Also, the $\mathrm{K}_{\mathrm{h}}$ distribution in layer 5 was believed to be too variable. To account for the first problem, structural features (which generally are linear features) were assigned to cell walls rather than a complete cell. Thus, $\mathrm{K}_{\mathrm{h}}$ could be reduced on only one cell wall rather than all four walls. Altogether, there were about 1,820 cell walls in which hydraulic conductivity was reduced (125 in the Saddle Mountains unit, 400 in the Wanapum unit, 735 in the upper Grande Ronde, and 560 in the lower Grande Ronde). For the second problem, $K_{h}$ of layer 5 was reduced from that of layer 4 by a constant, 0.86 . This constant is the average of all the calculated change values.

The use of these estimates in the model resulted in reasonable calculated heads and the estimates also supported the conceptual model. The $\mathrm{K}_{\mathrm{h}}$ values were now relatively uniform, regionalized over broad areas. The large variations in $\mathrm{K}_{\mathrm{h}}$ inherent in basalt, combined with the discretization of the aquifer system used in the ground-water model, implies that a simplified, uniform conductivity distribution should be a goal of the calibration. Hydrologically, this represents equivalent $K_{h}$ for the scale of interest. Thus, the current $K_{h}$ distributions were 
analyzed in conjunction with the difference between the observed and calculated lateral and vertical head gradients. A refined, regionalized distribution was derived and consists of nearly constant values over large areas. In some local areas, adjustments to these estimates were still necessary to improve the head match. Additionally, multiplying factors for cell walls representing structural features were refined during the last stages of model calibration. Final, multiplying factors derived for structural features ranged from 0.01 to 0.72 with a median of about 0.18 . Twenty percent of the factors were smaller than 0.18 , and 20 percent of the factors were larger than 0.27 . Model-derived areal distributions of lateral hydraulic conductivity of basalt are shown on plate 5 , and descriptive statistics are listed in table 1 . The model-derived values for the basalt units ranged from about $1 \times 10^{-6}$ to $1 \times 10^{-4} \mathrm{ft} / \mathrm{s}$ and had a median value of about $1.7 \times 10^{-5} \mathrm{ft} / \mathrm{s}$ (values are rounded).

\section{Transmissivity}

Cell transmissivity $(T)$ was calculated by multiplying the model-derived $\mathrm{K}_{\mathrm{h}}$ by an estimated saturated thickness value. The saturated thickness values were calculated from gridded values of water levels, structure contours, and thickness contours. Hand-drawn contours of the original point data (Whiteman, 1986; Drost and others, 1990) were digitized, gridded on the basis of a surface-fitting interpolation scheme (IMSL, 1982), and then manually edited.

The average estimated cell thickness of the overburden aquifer is about $260 \mathrm{ft}$ (median of $190 \mathrm{ft}$ ) and thickness ranges from about $30 \mathrm{ft}$ to $1,200 \mathrm{ft}$. The Saddle Mountains unit cell thickness averages about $410 \mathrm{ft}$ (median of $370 \mathrm{ft}$ ) and ranges from $20 \mathrm{ft}$ to $1,300 \mathrm{ft}$. The Wanapum unit cell thickness ranges from $30 \mathrm{ft}$ to 1,650 ft and averages about $570 \mathrm{ft}$ (median of $530 \mathrm{ft}$ ). The average cell thickness of the upper Grande Ronde is about 1,700 ft (median of 2,000 ft) and the thickness ranges from 100 to 3,000 ft. The estimated cell thicknesses for the lower Grande Ronde average 3,500 ft (median of 2,800 ft) and ranges from $200 \mathrm{ft}$ to $16,300 \mathrm{ft}$. Transmissivity distributions are shown on plate 6 , and descriptive statistics for the five model layers are listed in table 2 .

Table 2.--Descriptive statistics of transmissivity for the model layer

\begin{tabular}{|c|c|c|c|c|c|c|}
\hline & \multicolumn{6}{|c|}{ Layer number } \\
\hline & 1 & 2 & 3 & 4 & 5 & All \\
\hline & \multicolumn{6}{|c|}{ Unit name } \\
\hline & $\begin{array}{l}\text { Overburden } \\
\text { aquifer }\end{array}$ & $\begin{array}{c}\text { Saddle } \\
\text { Mountains unit }\end{array}$ & Wanapum unit & $\begin{array}{c}\text { Upper } \\
\text { Grande Ronde }\end{array}$ & $\begin{array}{c}\text { Lower } \\
\text { Grande Ronde }\end{array}$ & $\begin{array}{l}\text { Aquifer } \\
\text { system }\end{array}$ \\
\hline Statistics & \multicolumn{6}{|c|}{ Transmissivity, in square feet per second } \\
\hline Mean & $2.13 \times 10^{-1}$ & $5.29 \times 10^{-3}$ & $1.55 \times 10^{-2}$ & $4.25 \times 10^{-2}$ & $8.51 \times 10^{-2}$ & $1.35 \times 10^{-1}$ \\
\hline Minimum & $2.6 \times 10^{-5}$ & $2.8 \times 10^{-5}$ & $5.0 \times 10^{-5}$ & $4.8 \times 10^{-4}$ & $5.52 \times 10^{-4}$ & $4.80 \times 10^{-4}$ \\
\hline Maximum & $3.12 \times 10^{0}$ & $2.29 \times 10^{-2}$ & $1.08 \times 10^{-1}$ & $1.84 \times 10^{-1}$ & $4.80 \times 10^{-1}$ & $3.48 \times 10^{0}$ \\
\hline \multicolumn{7}{|l|}{ Deciles } \\
\hline 10 & $7.52 \times 10^{-4}$ & $4.86 \times 10^{-4}$ & $1.74 \times 10^{-3}$ & $6.02 \times 10^{-3}$ & $4.18 \times 10^{-3}$ & $7.88 \times 10^{-3}$ \\
\hline 20 & $1.85 \times 10^{-3}$ & $1.09 \times 10^{-3}$ & $3.29 \times 10^{-3}$ & $7.99 \times 10^{-3}$ & $7.48 \times 10^{-3}$ & $1.20 \times 10^{-2}$ \\
\hline 30 & $8.10 \times 10^{-3}$ & $1.74 \times 10^{-3}$ & $4.75 \times 10^{-3}$ & $1.01 \times 10^{-2}$ & $1.16 \times 10^{-2}$ & $1.82 \times 10^{-2}$ \\
\hline 40 & $2.20 \times 10^{-2}$ & $2.53 \times 10^{-3}$ & $6.48 \times 10^{-3}$ & $1.62 \times 10^{-2}$ & $2.04 \times 10^{-2}$ & $2.65 \times 10^{-2}$ \\
\hline 50 & $5.79 \times 10^{-2}$ & $3.70 \times 10^{-3}$ & $8.45 \times 10^{-3}$ & $1.97 \times 10^{-2}$ & $3.11 \times 10^{-2}$ & $3.85 \times 10^{-2}$ \\
\hline 60 & $1.05 \times 10^{-1}$ & $5.21 \times 10^{-3}$ & $1.10 \times 10^{-2}$ & $3.23 \times 10^{-2}$ & $5.57 \times 10^{-2}$ & $5.23 \times 10^{-2}$ \\
\hline 70 & $1.85 \times 10^{-1}$ & $6.83 \times 10^{-3}$ & $1.62 \times 10^{-2}$ & $4.97 \times 10^{-2}$ & $9.51 \times 10^{-2}$ & $1.01 \times 10^{-1}$ \\
\hline 80 & $3.13 \times 10^{-1}$ & $9.61 \times 10^{-3}$ & $2.36 \times 10^{-2}$ & $6.02 \times 10^{-2}$ & $1.37 \times 10^{-1}$ & $1.74 \times 10^{-1}$ \\
\hline 90 & $5.21 \times 10^{-1}$ & $1.27 \times 10^{-2}$ & $4.02 \times 10^{-2}$ & $1.51 \times 10^{-1}$ & $2.98 \times 10^{-1}$ & $4.16 \times 10^{-1}$ \\
\hline Number of cells & 969 & 1,229 & 4,414 & 6,977 & 4,310 & 7,016 \\
\hline
\end{tabular}




\section{Vertical hydraulic conductance per unit area}

Vertical hydraulic conductance per unit area (VCONT) is used to calculate flow of water between layers. Vertical hydraulic conductance per unit area, herein called vertical conductance or vertical hydraulic conductance, between the center of one layer to the center of an adjacent layer is equal to the ratio of the vertical hydraulic conductivity $\left(\mathrm{K}_{\mathrm{z}}\right)$ to the vertical grid spacing. Because of the lack of data for $\mathrm{K}_{\mathrm{z}}, \mathrm{K}_{\mathrm{h}}$ was used to estimate VCONT. Estimating VCONT on the basis of the saturated thicknesses and lateral hydraulic conductivities for adjacent pairs of model layers used the assumption that the pairs of layers are in direct contact or are separated only by a thin, fairly conductive confining bed, whose properties can be lumped in with those of the layers. This can be stated mathematically by the equation:

$$
\operatorname{vCONT}_{1,2}=\frac{2}{\frac{\Delta \mathrm{z}_{1}}{\mathrm{~K}_{\mathrm{z}_{1}}}+\frac{\Delta \mathrm{z}_{2}}{\mathrm{~K}_{\mathrm{z}_{2}}}}=\frac{2}{\frac{\Delta \mathrm{z}_{1}}{\mathrm{fctr}_{1} \mathrm{~K}_{\mathrm{h}_{1}}}+\frac{\Delta \mathrm{z}_{2}}{\mathrm{fctr}_{2} \mathrm{~K}_{\mathrm{h}_{2}}}}
$$

where,

$$
\begin{aligned}
\mathrm{z} & =\text { vertical grid spacing = saturated thickness, } \mathrm{L} \\
\mathrm{K}_{\mathrm{z}} & =\text { vertical hydraulic conductivity, } \mathrm{L} / \mathrm{T} \\
\mathrm{K}_{\mathrm{h}} & =\text { lateral hydraulic conductivity, } \mathrm{L} / \mathrm{T} \\
\mathrm{fctr} & =\text { ratio of vertical to lateral hydraulic conductivity, } \mathrm{K}_{\mathrm{z}} / \mathrm{K}_{\mathrm{h}}, \\
\mathrm{VCONT} & =\text { vertical conductance, }(1 / \mathrm{T}), \text { and } \\
1,2 & =\text { the upper and lower layer for any pair of layers. }
\end{aligned}
$$

Equation 5 is similar to McDonald and Harbaugh's (1988) equation 51, which applies when the $\mathrm{K}_{\mathrm{z}}$ 's between two adjacent layers are not the same. However, fctr $* K_{h}$ now replaces $K_{z}$. There is no hydrologic basis for distinguishing $\mathrm{fctr}_{1}$ from $\mathrm{fctr}_{2}$ for basalts; thus, one factor (fctr) common to both layers was used. Equation 5 can then be written as

$$
\operatorname{vcONT}_{1,2}=\frac{2^{*} \text { fctr }}{\frac{\Delta \mathrm{z}_{1}}{\mathrm{~K}_{\mathrm{h}_{1}}}+\frac{\Delta \mathrm{z}_{2}}{\mathrm{~K}_{\mathrm{h}_{2}}}}
$$

Estimates of fctr range from about 0.0005 to 0.1 on the basis of previous and ongoing studies (F. A. Packard, U.S. Geological Survey, written commun., 1986; Lum and others, 1990; Davies-Smith and others, 1988). The initial estimate of fctr, 0.003 , was adjusted on the basis of the possible effect of either a tight interbed between basalt layers or the absence of interbeds between each pair of layers. For the two confining units, lithologic data defined three types of areas; interbeds were predominantly clay, predominantly silt, or predominantly sand or absent. These areas were identified by row-column model grid indices. Fctr was reduced by one order of magnitude in the clay areas, left the same for silt areas, and increased by one order of magnitude in the sandy or absent interbed areas.

As a result of inaccurate model-calculated vertical head gradients, fctr was used only to calculate VCONT for adjacent layers where the confining unit is absent. For areas with fine-grained interbeds (silt or clay) whose vertical conductivity is significantly less than that of the basalts, a smaller value of VCONT was believed to be more correct. For example, reported $\mathrm{K}_{\mathrm{h}}$ 's of silt typically range from about $1 \times 10^{-9}$ to $1 \times 10^{-4} \mathrm{ft} / \mathrm{s}$ (Freeze and Cherry, 1979), whereas $K_{z}$ would be only 1 to 10 percent of these values. Thus, an interbed $100 \mathrm{ft}$ thick would give a VCONT ranging from $1 \times 10^{-13} \mathrm{~s}^{-1}$ to $1 \times 10^{-7} \mathrm{~s}^{-1}$. A calculated VCONT for basalt layers with no confining units whose cell centers are separated by $1,000 \mathrm{ft}$ would be about $1 \times 10^{-9} \mathrm{~s}^{-1}$. Comparing this value to the range of values 
for silt indicates that a silt interbed may not have any effect on VCONT for large values, or it may reduce it profoundly by as much as three orders of magnitude for small values. Assuming that for many areas the presence of a silt or clay interbed would reduce VCONT from that of pure basalt, equation 6 was reformulated for presence of silt or clay interbeds, as

$$
\frac{1}{\text { VCONT }_{1,2}}=\frac{1}{\frac{2^{*} \text { fctr }}{\Delta \mathrm{z}_{1}}+\frac{\Delta \mathrm{z}_{2}}{\mathrm{~K}_{\mathrm{h}_{1}}}+\frac{100}{\mathrm{~K}_{\mathrm{h}_{2}}}}+\frac{100}{\mathrm{~K}_{\text {silt }}} \text { or } \frac{\mathrm{K}_{\text {clay }}}{\text {, }}
$$

where, $\quad \mathrm{K}_{\text {silt }}=$ vertical hydraulic conductivity for silt, $\mathrm{L} / \mathrm{T}$,

$\mathrm{K}_{\text {clay }}=$ vertical hydraulic conductivity for clay, $\mathrm{L} / \mathrm{T}$,

$100=$ assumed thickness of confining unit, $\mathrm{L}$, and other variables are as previously defined.

To derive estimates of fctr, it was varied from 1 to $0.0001\left(\mathrm{~K}_{\mathrm{h}}\right.$ to $\mathrm{K}_{\mathrm{z}}$ ratios of 1 to 10,000$)$ and $\mathrm{K}_{\mathrm{z}}$ of the confining units was varied from $1 \times 10^{-7} \mathrm{ft} / \mathrm{s}$ to $1 \times 10^{-13} \mathrm{ft} / \mathrm{s}$ for model simulations. The best regional fit of calculated and observed heads and vertical head gradients was obtained using a value of fctr of $0.008\left(125: 1=\mathrm{K}_{\mathrm{h}} / \mathrm{K}_{\mathrm{z}}\right)$, $\mathrm{K}_{\text {silt }}=1 \times 10^{-10} \mathrm{ft} / \mathrm{s}$, and $\mathrm{K}_{\text {clay }}=1 \times 10^{-12} \mathrm{ft} / \mathrm{s}$.

Several things became apparent during this part of the model calibration: (1) Identification of lithologies from drillers' well logs is difficult, particularly distinguishing between clay and silt; (2) VCONT varied too much; (3) the distribution of silt and clay were incorporated subjectively into the calibration process; and (4) the largest changes in the observed vertical head gradients did not always occur across the interbeds (especially the Wanapum-Grande Ronde interbed), but sometimes occurred 50 to $200 \mathrm{ft}$ into the basalt unit below the interbed. The last item indicates that, in places, the basalt material can be "tighter" or more confining than a clay interbed. To account for the above items and to simplify the regional model, a constant value of fctr for each layer was used in equation 6; that is, the silt and clay conductances were not used. The initial estimates were 0.1 for the overburden aquifer, 0.0005 for the Saddle Mountains unit, 0.001 for the Wanapum unit, and 0.1 for the upper Grande Ronde. The areally extensive Saddle Mountains-Wanapum interbed consists predominantly of tight materials, accounting for the small Saddle Mountains unit value.

Using constant values for each layer, fctr was derived again on the basis of adjustments for model simulations. A value of 0.15 for layer 1 gave the best regional fit of observed and calculated gradients; smaller (tighter) values gave vertical gradients that were too large. This value is reasonable on the basis of the rapid and large head increases in the Saddle Mountains and Wanapum units after the onset of surface-water irrigation on the plateau. A value of 0.0003 gave the best regional fit for both the Saddle Mountains and Wanapum units. Using larger values resulted in vertical gradients that were too small, and using a smaller value of 0.0002 did not change appreciably the vertical gradients calculated with fctr as 0.0003 ; however, the 0.0002 value appeared to be regionally too tight. A value of 0.002 between the upper and lower Grande Ronde layers gave the best regional fit. The ground-water model was sensitive to the fctr value between these layers; in some areas a smaller value was better, and conversely, in other areas a larger value was better. This is probably because of the extent of the lower Grande Ronde layer. The movement of water in the parts of this layer more than about 500 to $1,000 \mathrm{ft}$ thick is probably slow with little circulation. Similarly, ground water in this layer is probably more confined with depth and $\mathrm{K}_{\mathrm{h}}$ can be expected to decrease with depth. Therefore, modeling the lower Grande Ronde as one layer whose parameters are based on the upper Grande Ronde results in the inability to concurrently move enough water in thin sections and represent slow circulation in the thick sections. 
VCONT was adjusted to account for the effects of water movement in uncased wells that penetrate more than one unit on the basis of the method presented by Bennett and others (1982). The method of Bennett and others (1982) incorporates additional terms for multiaquifer (composite) well effects on the vertical hydraulic conductivity for writing the finite-difference equations of ground-water flow. Bennett and others (1982) then note that for the case of wells only affecting two adjacent layers (as assumed for this study), only the coefficient of the head difference between those layers (McDonald and Harbaugh's (1988) cv; equation 14) is altered. Instead of modifying the computer code for the ground-water model, this alteration or change in the cv-coefficient is calculated outside of the model, and is added to VCONT (cv divided by cell area) which is input to the model. This additional term (CW or well conductance) was added to VCONT for any cell that had a composite well. Bennett and other's (1982) equation 5 can be written for two adjacent layers as

$$
\mathrm{CW}=\frac{2 \pi^{*} \mathrm{~T}_{\mathrm{k}}^{*} \mathrm{~T}_{\mathrm{k}+1}}{2.3 \log \left(\mathrm{r}_{\mathrm{a}} / \mathrm{r}_{\mathrm{w}}\right)^{*}\left(\mathrm{~T}_{\mathrm{k}}+\mathrm{T}_{\mathrm{k}+1}\right)}
$$

where $\mathrm{T}$ is the transmissivity of a cell, $\mathrm{k}$ and $\mathrm{k}+1$ are subscripts denoting the layers that the composite well penetrates, $r_{w}$ is the radius of the well, and $r_{a}$ is the (smaller of row or column spacing) divided by 4.81. CW is divided by $\Delta x$ and $\Delta y$, the lengths of the cell in the $\mathrm{x}$ and $\mathrm{y}$ directions, before it is added to VCONT. This method provided good results only under the assumption that there was only one composite well in any cell and that the well was located at the cell center. Methods accounting for more than one well or for wells located elsewhere in a cell did not work. Using this method, VCONT increased in 1,479 cells.

The estimates of VCONT derived from model calibration for the basalt units ranged from $4.5 \times 10^{-13}$ to $4 \times 10^{-8} \mathrm{~s}^{-1}$. Previously derived VCONTs for the basalt units in the study area (F. A. Packard, U.S. Geological Survey, written commun., 1986; Prych, 1983; Davies-Smith and others, 1988; Skrivan, 1987) ranged between $2 \times 10^{-12}$ and $5 \times 10^{-9} \mathrm{~s}^{-1}$. The distribution of VCONT derived from the time-averaged calibration is shown on plate 7 , and descriptive statistics for the model-derived values are presented in table 3. Because the time-averaged model represents the observed aquifer conditions (paucity of predevelopment data), only these VCONTs are presented in this report.

Table 3.--Descriptive statistics of vertical hydraulic conductance per unit area for the upper four model layers

\begin{tabular}{ccccc}
\hline \multicolumn{3}{c}{ Layer number } & \\
\hline 1 & 2 & Unit name & 3 & 4 \\
\hline $\begin{array}{c}\text { Overburden } \\
\text { aquifer }\end{array}$ & $\begin{array}{c}\text { Saddle } \\
\text { Mountains unit }\end{array}$ & Wanapum unit & $\begin{array}{c}\text { Upper } \\
\text { Grande Ronde }\end{array}$
\end{tabular}

Statistics

\begin{tabular}{|c|c|c|c|c|}
\hline Mean & $1.25 \times 10^{-6}$ & $1.09 \times 10^{-9}$ & $3.66 \times 10^{-10}$ & $4.10 \times 10^{-11}$ \\
\hline Minimum & $2.00 \times 10^{-12}$ & $5.00 \times 10^{-13}$ & $5.00 \times 10^{-13}$ & $4.50 \times 10^{-13}$ \\
\hline Maximum & $1.01 \times 10^{-5}$ & $3.54 \times 10^{-8}$ & $2.70 \times 10^{-8}$ & $4.98 \times 10^{-11}$ \\
\hline \multicolumn{5}{|l|}{ Deciles } \\
\hline 10 & $1.01 \times 10^{-11}$ & $3.01 \times 10^{-12}$ & $4.98 \times 10^{-13}$ & $1.01 \times 10^{-12}$ \\
\hline 20 & $1.01 \times 10^{-11}$ & $6.02 \times 10^{-12}$ & $5.45 \times 10^{-13}$ & $4.98 \times 10^{-11}$ \\
\hline 30 & $4.00 \times 10^{-10}$ & $1.07 \times 10^{-11}$ & $2.51 \times 10^{-12}$ & $4.98 \times 10^{-11}$ \\
\hline 40 & $6.12 \times 10^{-9}$ & $1.16 \times 10^{-11}$ & $6.02 \times 10^{-12}$ & $4.98 \times 10^{-11}$ \\
\hline 50 & $2.63 \times 10^{-8}$ & $2.12 \times 10^{-11}$ & $6.02 \times 10^{-12}$ & $4.98 \times 10^{-11}$ \\
\hline 60 & $6.32 \times 10^{-8}$ & $3.78 \times 10^{-11}$ & $1.08 \times 10^{-11}$ & $4.98 \times 10^{-11}$ \\
\hline 70 & $1.03 \times 10^{-7}$ & $1.01 \times 10^{-10}$ & $1.97 \times 10^{-11}$ & $4.98 \times 10^{-11}$ \\
\hline 80 & $1.73 \times 10^{-7}$ & $1.01 \times 10^{-10}$ & $4.26 \times 10^{-11}$ & $4.98 \times 10^{-11}$ \\
\hline 90 & $1.01 \times 10^{-5}$ & $1.11 \times 10^{-9}$ & $9.03 \times 10^{-11}$ & $4.98 \times 10^{-11}$ \\
\hline Number of cells & 969 & 1,229 & 4,375 & 4,310 \\
\hline
\end{tabular}


Vertical hydraulic conductivity also was estimated for each pair of layers using equation 6 . The estimates of $\mathrm{K}_{\mathrm{z}}$ for the overburden aquifer range from $4.4 \times 10^{-12}$ to $1.6 \times 10^{-2} \mathrm{ft} / \mathrm{s}$ and have a median of $2.1 \times 10^{-5} \mathrm{ft} / \mathrm{s}$. The median is about an order of magnitude smaller than the model-derived median $K_{h}$. The estimates of $K_{z}$ for the basalt units range from $5.4 \times 10^{-10}$ to $8.3 \times 10^{-5} \mathrm{ft} / \mathrm{s}$ and have a median of $1.5 \times 10^{-8} \mathrm{ft} / \mathrm{s}$. The median is about three orders of magnitude smaller than the median $\mathrm{K}_{\mathrm{h}}$. The ratio of $\mathrm{K}_{\mathrm{h}}$ to $\mathrm{K}_{\mathrm{z}}$ varies widely throughout the plateau and averages about 25:1 for the overburden aquifer. The ratio for the basalt units is typically 1,000:1 to 1,500:1. However, the ratio averages about 250:1 for the basalt units because of locally large vertical conductances at or near the rivers.

\section{$\underline{\text { Storage coefficient }}$}

Storage coefficient (S) values are not input into either the steady-state or time-averaged model. However, time averaging uses $S$ to account for the change in aquifer storage over the averaging period. Storage coefficients were not estimated directly for this study because of the known variability in these values and the lack of information for making reliable areal estimates. However, selected published values for all model units are presented in table 4 . The values in table 4 were obtained from aquifer tests and from numerical ground-water modeling studies; when possible, the values for this study's aquifer units are given. Additionally, the potential range in the storage coefficient has been estimated for the three basalt units.

The specific storage $\left(\mathrm{S}_{\mathrm{s}}\right)$ was estimated from the relation of Jacob (1940) for confined aquifer conditions under the assumption that the compressibility of the skeleton of the aquifer is small in comparison to the expansibility of water. Using representative values for porosity $(0.04)$, the bulk modulus of elasticity of water $\left(3 \times 10^{5} \mathrm{lb} / \mathrm{in} .{ }^{2}\right)$, and specific weight per unit area of water $\left(0.433 \mathrm{lb} / \mathrm{in}^{-2} \mathrm{ft}^{-1}\right)$ gave an estimated specific storage of about $6 \times 10^{-8} \mathrm{ft}^{-1}$. The potential range in storage coefficients then can be estimated by multiplying the estimated specific storage value by a representative aquifer thickness. Representative values of aquifer thickness for each basalt unit used were the minimum, median, and maximum of the gridded data. The estimated minimum, median, and maximum storage-coefficient values for the Saddle Mountains unit were $3.7 \times 10^{-6}-3.9 \times 10^{-5}-1.1 \times 10^{-4}$, respectively; the Wanapum unit values were $3.0 \times 10^{-6}-4.5 \times 10^{-5}-2.3 \times 10^{-4}$, respectively; and the Grande Ronde unit values were $1.2 \times 10^{-5}-2.4 \times 10^{-4}-1.1 \times 10^{-3}$, respectively.

The values for the overburden materials (table 4 ) range from 0.0002 to 0.2 and generally represent the specific yield. The larger values are model derived and the smaller values are calculated from aquifer tests. The modelderived values are believed to be more representative than the calculated values of regional conditions through the full depth of the overburden aquifer, and thus a specific yield value between 0.1 and 0.2 appears to be a representative value.

Storage-coefficient values for the basalt materials (table 4) range from about $1.4 \times 10^{-6}$ to $3.1 \times 10^{-2}$ and represent water-table conditions with low porosity, leaky artesian, and confined conditions, where the values approach the compressibility of water. For the overburden aquifer, the model-derived values are generally larger than both aquifer test data and the estimated range information, and are believed to be more regionally representative. A derived regional basalt value used in the calculations for the change-in-storage term was 0.04 . 
Table 4.--Summary of selected storage-coefficient estimates for the Columbia Plateau

\begin{tabular}{|c|c|c|c|c|}
\hline Geologic unit & Hydrogeologic unit & $\begin{array}{l}\text { Storage } \\
\text { coefficient/ } \\
\text { specific } \\
\text { yield }\end{array}$ & $\begin{array}{l}\text { Method }{ }^{1} \\
\text { of } \\
\text { deter- } \\
\text { mination }\end{array}$ & References \\
\hline Fluvial & Overburden aquifer & 0.20 & Model & Bolke and Skrivan, 1981 \\
\hline Glaciofluvial & --Do-- & $.03-0.2$ & AT & Newcomb and others, 1972 \\
\hline Ringold Formation & --Do-- & $2.0 \times 10^{-4}$ & & - \\
\hline Touchet Beds & --Do-- & .1 & Model & Prych, 1983 \\
\hline Glaciofluvial & --Do-- & $.06-0.2$ & AT & Bierschenk, 1959 \\
\hline Overburden & --Do-- & .06 & AT & --------Do------- \\
\hline Ringold Formation & --Do-- & .1 & AT, Model & Tanaka and others, 1974 \\
\hline Glaciofluvial & --Do-- & .15 & & 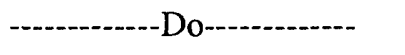 \\
\hline Basalt & Wanapum & $\begin{array}{l}1.2 \times 10^{-4} \\
2.2 \times 10^{-5}\end{array}$ & AT & $\begin{array}{l}\text { Eddy, } 1976 \\
----D o--\end{array}$ \\
\hline \multirow{2}{*}{$\begin{array}{l}\text { Basalt } \\
1984\end{array}$} & $\begin{array}{l}\text { Saddle Mountains- } \\
\text { Wanapum }\end{array}$ & $3.2 \times 10^{-2}$ & Model & $\begin{array}{l}\text { A. Smith, U. S. Geological } \\
\text { Survey, written commun., }\end{array}$ \\
\hline & Grande Ronde & $5.2 \times 10^{-4}$ & Model & 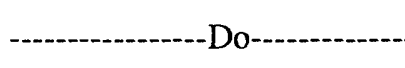 \\
\hline Basalt & Mainly Wanapum & $\begin{array}{l}4.7 \times 10^{-4} \\
9.0 \times 10^{-5} \\
4.75 \times 10^{-3}\end{array}$ & AT & McNish and Barker, 1976 \\
\hline Basalt & Wanapum & $2.0 \times 10^{-4}$ & AT & Price, 1960 \\
\hline Basalt & $\begin{array}{l}\text { Wanapum and } \\
\text { Grande Ronde }\end{array}$ & $\begin{array}{l}\text { 6. } \times 10^{-4} \\
1.4 \times 10^{-6}\end{array}$ & $\mathrm{AT}$ & LaSala and Doty, 1971 \\
\hline Basalt & $\begin{array}{l}\text { Wanapum- } \\
\text { Grande Ronde }\end{array}$ & $\begin{array}{l}1.5 \times 10^{-3} \\
2.0 \times 10^{-3} \\
6.0 \times 10^{-3}\end{array}$ & Model & Luzier and Skrivan, 1975 \\
\hline $\begin{array}{l}\text { Basalt } \\
\text { Geological }\end{array}$ & Saddle Mountains, & $1.0 \times 10^{-2}$ & Model & F. A. Packard, U. S. \\
\hline 1987 & $\begin{array}{l}\text { Wanapum, and } \\
\text { Grande Ronde }\end{array}$ & $1.0 \times 10^{-3}$ & & Survey, written commun., \\
\hline Basalt & Saddle Mountains & $2.5 \times 10^{-3}$ & AT, Model & Tanaka and others, 1974 \\
\hline Basalt & Not determined & $\begin{array}{l}3.1 \times 10^{-2} \\
1.9 \times 10^{-3} \\
4.6 \times 10^{-4} \\
5.0 \times 10^{-5}\end{array}$ & $\mathrm{AT}$ & $\begin{array}{l}\text { Oregon Water Resources } \\
\text { Department from A. Smith, } \\
\text { U.S. Geological Survey, } \\
\text { written commun., } 1984\end{array}$ \\
\hline Basalt & $\begin{array}{l}\text { Wanapum and } \\
\text { Grande Ronde }\end{array}$ & $\begin{array}{l}7.6 \times 10^{-4} \\
\text { to } \\
3.0 \times 10\end{array}$ & AT & Tanaka and others, 1979 \\
\hline
\end{tabular}

\footnotetext{
${ }^{1}$ Model, derived from numerical ground-water model; AT, derived from aquifer tests.
} 


\section{Stream-leakage coefficients}

River cells represented all major rivers and most perennial streams in the initial model. The following form of Darcy's law approximates the flux of water between a river and the aquifer in a cell:

$$
\mathrm{Q}=\mathrm{K}_{\mathrm{s}} \mathrm{A}\left(\mathrm{h}_{\mathrm{s}}-\mathrm{h}_{\mathrm{a}}\right)
$$

where,

$$
\begin{aligned}
\mathrm{Q} & =\text { flow rate from stream to aquifer, } \mathrm{L}^{3} / \mathrm{T}, \\
\mathrm{K}_{\mathrm{S}} & =\text { stream-leakage coefficient, } 1 / \mathrm{T}, \\
\mathrm{h}_{\mathrm{s}} & =\text { altitude of stream surface, } \mathrm{L}, \\
\mathrm{h}_{\mathrm{a}} & =\text { altitude of aquifer head, } \mathrm{L}, \text { and } \\
\mathrm{A} & =\text { area of streambed, } \mathrm{L}^{2} .
\end{aligned}
$$

Values of $h_{s}$ were obtained from available river-stage data; where river-stage altitude data were not available, the $h_{s}$ value was assigned as the average land-surface altitude at the stream bank as shown on topographic maps. The value of area, A, between nodes was calculated as the product of length and the average width of the stream for that model cell.

Constant values of $\mathrm{K}_{\mathrm{S}}$ estimated from values from F. A. Packard (U.S. Geological Survey, written commun., 1986), Bolke and Vaccaro (1981), and Prych (1983) initially were used because of the size of the modeled area and the large number of river cells. A value of $5 \times 10^{-5} \mathrm{~s}^{-1}$ was used for all river cells that reside in the overburden model layer. For basalt river cells, a value of $7 \times 10^{-7} \mathrm{~s}^{-1}$ was used, except for the cells surrounding dams. In these areas, the following values were used: $1 \times 10^{-7} \mathrm{~s}^{-1}$ for cells situated immediately upstream of dams, $2-7 \times 10^{-7} \mathrm{~s}^{-1}$ for transition cells in pools between dams and upper pool reaches, and $9 \times 10^{-7} \mathrm{~s}^{-1}$ for cells immediately below dams. For the steady-state simulation, the latter three values were not used because there were no dams. The $\mathrm{K}_{\mathrm{s}}$ values for the steady-state simulation were assumed to represent the vertical hydraulic conductivity of the rock material the river resides in, divided by an effective "streambed thickness."

Reliability of the initial estimates was tested by calculating fluxes using McDonald and Harbaugh's (1988) equation 18 with gridded hydraulic head data and estimates of river stage, widths, and lengths. Fluxes computed by this method were generally reasonable when compared with the available or estimated average, long-term ground-water discharge to each stream.

During model calibration, $\mathrm{K}_{\mathrm{s}}$ values were adjusted by as much as 10 percent in model cells where the computed heads were high or in model cells that desaturated during computations. Resulting analysis of calculated heads and fluxes, relation between land surface and observed heads, and streamflow hydrographs led to redefinition of the river cell distribution. About 600 of the initial cells remained river cells, and about 1,500 of the original were redefined as drain cells. Drain cells only can gain water from the aquifer system and cannot lose water to the system. With this redefinition, the calculated heads were closer to the observed and the model was numerically more stable.

Next, the $\mathrm{K}_{\mathrm{s}}$ values were recalculated as

$$
\mathrm{K}_{\mathrm{s}}=\mathrm{K}_{\mathrm{h}} \mathrm{fctr} /(0.5 \mathrm{~b})
$$

where,

$\mathrm{b}=$ saturated thickness of layer river is in, $\mathrm{L}$,

fctr $=$ ratio of vertical to lateral hydraulic conductivity $\left(\mathrm{K}_{\mathrm{v}} / \mathrm{K}_{\mathrm{h}}\right), \mathrm{L}^{0}$, and

$\mathrm{K}_{\mathrm{h}}$ = lateral hydraulic conductivity of model cell for layer river is in, $L / T$. 
Equation 10 is similar to the conceptual model of the previous assigning of $\mathrm{K}_{\mathrm{s}}$ values; that is, the movement of water to and from the rivers was assumed to consist of mainly a vertical flow component; $(0.5 \mathrm{~b})$ in equation 10 approximates the flow path from the center of a cell to the river bed.

Although the matches of head and river fluxes were improved in subsequent simulations, heads were calculated too high at or near river cells. Therefore, the Dupuit-Forchheimer approximation for discharge to a stream (Bear, 1979) was used to estimate an "equivalent" stream-leakage coefficient. This conceptual model assumes lateral movement of water to and from rivers. The Dupuit-Forchheimer formula for discharge from a water-table aquifer to one side of a stream $\left(\mathrm{Q}_{1 / 2}\right)$ may be written as:

$$
Q_{1 / 2}=\frac{1 K_{e}}{2 x}\left[\left(h_{a}-h_{b}\right)^{2}-\left(h_{s}-h_{b}\right)^{2}\right]
$$

where, $\quad h_{b}=$ the altitude of the streambed, $L$,

$\mathrm{h}_{\mathrm{s}}=$ the altitude of the stream, $\mathrm{L}$,

$\mathrm{h}_{\mathrm{a}}=$ the head in the aquifer at distance $\mathrm{x}$ from the stream, $\mathrm{L}$,

$\mathrm{K}_{\mathrm{e}}=$ the lateral hydraulic conductivity, $\mathrm{L} / \mathrm{T}$, and

$1=$ the length of stream, $L$.

Doubling the right-hand side of equation 11 to account for discharge to both sides of the stream, rearranging, equating to the right-hand side of equation 9 , and solving for $\mathrm{K}_{s}$, gives

$$
R C \approx 4 K_{e}\left(h_{a}+h_{s}-2 h_{b}\right)
$$

where river conductance (RC--a proportionality factor) now replaces $\mathrm{K}_{\mathrm{s}} \mathrm{A}$ in equation 9 . The cell head now is assumed to be equivalent to the aquifer head at a distance half way between the stream and the cell wall $(x \approx 1 / 4)$. For small streams, $\left(\mathrm{h}_{\mathrm{s}}-\mathrm{h}_{\mathrm{b}}\right)$ is negligible and $\mathrm{RC}$ is approximately equal to four times the lateral hydraulic conductivity times the average saturated thickness of the aquifer above the streambed. By this method, RC is calculated for new estimates of $\mathrm{K}_{\mathrm{s}} \mathrm{A}$ in equation 9.

Results of simulations using the above formulation were better, but still were not satisfactory. Because most of the river cells are occupied by large rivers, some of which cover a large part of the cell, the product of $\mathrm{K}_{\mathrm{s}}$ (from equation 10) multiplied by A was added to RC; this assumes that vertical flow also contributes to the net flux of water. This formulation then was used for part of the remaining calibration process.

Adjustments to $\left(\mathrm{RC}+\mathrm{K}_{\mathrm{s}} \mathrm{A}\right)$ were made manually toward the end of the calibration process because of the uncertainty of the parameters in equation 9 , the large size of model cells, and the modeling of the localized stream-leakage process (a complex three-dimensional process) as a spatially averaged two-dimensional process. Similar to other hydraulic characteristics, adjustments were for determining regionalized, uniform values. The smallest value that still produced reasonable hydraulic heads at or near the river cells was estimated for selected reaches or complete rivers. Choosing the smallest value prevented a river cell from essentially acting as a constant head boundary. Statistics on the derived stream-leakage coefficients $\left(R C+K_{s} A\right)$ for the river cells are presented in table 5, and the location and model layer of the river cells are shown on plate $8 \mathrm{a}$ and on plate 2. Both table 5 and plate $8 \mathrm{a}$ are for the time-averaged model. 
Table 5.--Descriptive statistics for the stream- and drain-leakage and general-head-boundary coefficients

[GHB $=$ General head boundary, values in feet squared per second]

\begin{tabular}{lccc}
\hline & \multicolumn{3}{c}{ Coefficients } \\
\cline { 2 - 4 } Statistics & River & Drain & GHB \\
\hline Mean & 3.1 & 1.95 & $8.1 \times 10^{-3}$ \\
Minimum & .5 & .1 & $1.0 \times 10^{-6}$ \\
Maximum & 11.0 & 10.0 & $5.0 \times 10^{-2}$ \\
Deciles & & & \\
10 & 1.0 & .3 & $5.0 \times 10^{-5}$ \\
20 & 1.0 & 1.0 & $1.0 \times 10^{-3}$ \\
30 & 1.0 & 1.0 & $1.0 \times 10^{-3}$ \\
40 & 1.0 & 1.0 & $2.5 \times 10^{-3}$ \\
50 & 1.0 & 1.0 & $4.0 \times 10^{-3}$ \\
60 & 1.0 & 1.0 & $5.0 \times 10^{-3}$ \\
70 & 1.0 & 1.0 & $5.0 \times 10^{-3}$ \\
80 & 10.0 & 1.0 & $5.0 \times 10^{-2}$ \\
90 & 10.0 & 9.0 & 560 \\
\hline
\end{tabular}

\section{Drain-leakage coefficients}

Streams.--Stream-drain cells represent streams or surface-drainage features that are assumed to only discharge water from the aquifer system. Discharge along a length of stream in a drain cell is calculated by:

$$
\begin{gathered}
Q=K_{d}\left(h_{a}-h_{d}\right) \text { if } h_{a}>h_{d} \\
\left(Q=0.0 \text { if } h_{a} \leq h_{d}\right),
\end{gathered}
$$

where, $\quad Q=$ flow rate from aquifer to stream, $\mathrm{L}^{3} / \mathrm{T}$,

$K_{d}=$ drain-leakage coefficient, $L^{2} / T$,

$\mathrm{h}_{\mathrm{d}}=$ altitude of the stream, $\mathrm{L}$, and

$h_{a}=$ altitude of aquifer head, $L$.

$\mathrm{K}_{\mathrm{d}}$ in equation 13 was calculated using equation 12 ; that is,

$$
K_{d}=4 K_{e}\left(h_{a}+h_{d}-2 h_{b}\right),
$$

where all variables are as previously defined. 
Highly variable topography and lack of information on the head distributions in complex and steep terrain areas resulted in extreme variability in $h_{a}$ and $h_{d}$ and, thus, in $K_{d}$. In those areas (basalt is always at the land surface), $K_{d}$ was assigned a nearly uniform value. As with the stream-leakage coefficients, $K_{d}$ was regionalized toward the end of the calibration process. One of the reasons that regionalized $K_{d}$ (and $R C+K_{s} A$ ) values are appropriate is that ground-water discharge generally is not controlled by an impeding streambed layer. The coarse-grained streambeds more commonly have higher conductivities than the aquifer material, or the streambed is the aquifer itself. Descriptive statistics for the 2,841 values of $\mathrm{K}_{\mathrm{d}}$ are listed in table 5, and the areal distribution of drain cells are shown on plate $8 \mathrm{~b}$; see also plate 2 . Information presented in table 5 and plate $8 \mathrm{~b}$ is for the time-averaged model.

Farm drains.--Farm-drain cells represent ditches, wasteways, and tile drains established to drain excess irrigation waters in order to prevent root-zone soil water-logging. Farm drains occur in the Yakima River valley, the Columbia Basin Irrigation Project, the Walla Walla River basin, and the Umatilla River basin. Farm drains are included in the time-averaged model but not in the predevelopment model. For farm-drain cells, the main factors accounted for were a realistic areal distribution of drains and $K_{d}$ values sufficiently large to "hold down" the heads, as was demonstrated in an investigation of the Quincy basin in the Columbia Basin Irrigation Project (H. H. Bauer, U.S. Geological Survey, written commun., 1985). Initial values of $K_{d}$ in equation 13 for each farm-drain cell were based on the total footage of drains in a cell and the overburden aquifer's median $K_{h}$ value. As with the stream drains, $K_{d}$ values later were regionalized. Values of $K_{d}$ are presented in table 5, and the areal distribution of farm-drain cells is shown in conjunction with the stream-drain cells (plate $8 b$ ).

\section{Lake-leakage coefficients}

Lakes and reservoirs were accounted for in two ways: a water body directly connected to a river was modeled as a river cell (discussed previously), and lakes or reservoirs not part of a system of river cells were modeled as drain cells. Equation 13 was assumed to hold for each of the lake cells, where $K_{d}$ is equal to $K_{L}$ multiplied by $A$, and $\mathrm{K}_{\mathrm{L}}$ is the lake-leakage coefficient $(1 / \mathrm{T})$. The surface area of a lake was apportioned among all model lake cells. Typically, only hydrologically significant lakes, as indicated by the water-level contour maps, were included in the model (Bauer and others, 1985; Whiteman, 1986).

Initial values for the first type of lakes or reservoirs were the same as that used initially for free-flowing streams on the basalt and overburden, as presented previously in the "Stream-Leakage Coefficients" subsection. Initial values of the second type of lake-leakage coefficients, $\mathrm{K}_{\mathrm{L}}$, were set uniformly at $1.0 \times 10^{-7} \mathrm{~s}^{-1}$ for lakes residing in a basalt layer and as $1.0 \times 10^{-5} \mathrm{~s}^{-1}$ for lakes residing in the overburden layer. The overburden value, lower than for streams, assumes that the lakes are part of the overburden ground-water system, but that sedimentation lowers the conductivity. The initial estimate for the basalt cells represents river pools, where sedimentation is greatest.

As with river cells, reliability of the initial estimates was tested by calculating fluxes, using the McDonald and Harbaugh's (1988) equation 18, before model operation. The equation calculated a net flux of about $17 \mathrm{ft}^{3} / \mathrm{s}$ for all lakes, with most values being less than $2 \mathrm{ft}^{3} / \mathrm{s}$. Although these values were reasonable, the same relation used for stream-drain cells (eq. 14) was used later to estimate $K_{L} A$. Like the stream drains, regionalized values of $K_{L} A$ were derived toward the end of the calibration process. Statistics on the final calibrated lake-leakage coefficients are included with values presented in table 5. The model lake cells and the model layer they reside in were shown previously on plate $8 \mathrm{a}$ and $8 \mathrm{~b}$ with the river and drain cells. The time-averaged model used additional lake cells to represent lakes created by the delivery, application, and infiltration of surface water for irrigation. 


\section{General head boundary coefficients}

The general head boundary (GHB) formulation simulates exterior and interior seepage-face boundaries. The conceptual model for this formulation (fig. 6) was discussed in the "Boundary Conditions" subsection. The mathematical formulation for this model is McDonald and Harbaugh's (1988) equation 78:

$$
\mathrm{Q}=\mathrm{C}\left(\mathrm{h}_{\mathrm{sb}}-\mathrm{h}_{\mathrm{a}}\right)
$$

where $C$ is the GHB coefficient (proportionality factor), $L^{2} / T, h_{s b}$ is the head at the source boundary, $L$, and other variables are as previously defined.

C initially was assigned the transmissivity value (T) of the GHB cell. Although $\mathrm{C}$ is a head-dependent variable, similar to the stream-leakage coefficient, it was assumed to be proportional to the $T$ of the cell. The reasons for this assumption were the large size of the model cells, the lack of accurate information on the controling head at the source boundary (many GHBs are situated in rugged terrain), and the inability to estimate accurately the flux, Q, out of a cell.

During the calibration process, $C$ was adjusted by multiplying $\mathrm{T}$ by a factor that ranged from 0.1 to 0.8 . However, the results of the regionalization of the other model parameters and the knowledge of the averaging procedures inherent in defining the GHB parameters led to regionalizing C. Estimating nearly uniform values of C, on the basis of the median value of $\mathrm{C}$ for each layer, and adjusting these values in some localized areas produced the final $\mathrm{C}$ values. Descriptive statistics of the GHB coefficients are listed in table 5, and the distribution of GHBs was shown previously (plate 2) for each layer and is shown on plate $8 \mathrm{c}$ for the complete aquifer system. Note that the median value of $\mathrm{C}$ is less than the 20-percentile $\mathrm{T}$-value for the lower three layers (table 2).

\section{Results of Model Calibration}

Assessment of model accuracy, reliability, and goodness-of-fit was completed by comparing the difference between model-calculated heads from the time-averaged simulation and the gridded heads from the hand-drawn head configurations (Whiteman, 1986; Lane and Whiteman, 1989). Additionally, estimated observed and model-calculated discharge to selected basins was used for assessment of the model. However, this information is discussed later in the "Discharge to Basins and Streams" section.

The gridded or contoured values represent the best regional interpretation of the point head data. In many instances, head data from a well are not representative of a vertically averaged head, either locally or across a cell. This is because of the locally large lateral and vertical head gradients across such a cell and because many wells are either composite or partially penetrating. However, the contoured and gridded head data, which were derived by accounting for partial penetration and composite well effects, are also uncertain for some of the high altitude areas, within areas of sparse data, and for the deeply buried upper Grande Ronde. Virtually, no head data are available for the lower Grande Ronde; calibration results for the lower Grande Ronde are assumed to be adequate for this study and are not discussed in this subsection.

The frequency distribution for class intervals of the difference (residuals) between time-averaged model-calculated and observed (gridded-contoured) heads for all cells in each layer for the upper four model layers are shown in figure 6; positive residuals mean greater than observed, and negative residuals mean less than observed. The classes are in 100- $\mathrm{ft}$ intervals, except the two $100-\mathrm{ft}$ class intervals surrounding the $0.0 \mathrm{ft}$ (perfect fit) point. This combined $200-\mathrm{ft}$ interval was divided further into four $50-\mathrm{ft}$ intervals because about 80 percent of the values lie within these intervals. Additionally, a few cells had a calculated head that was more than $1,000 \mathrm{ft}$ below the gridded head; these large negative residuals have been combined into one class. 


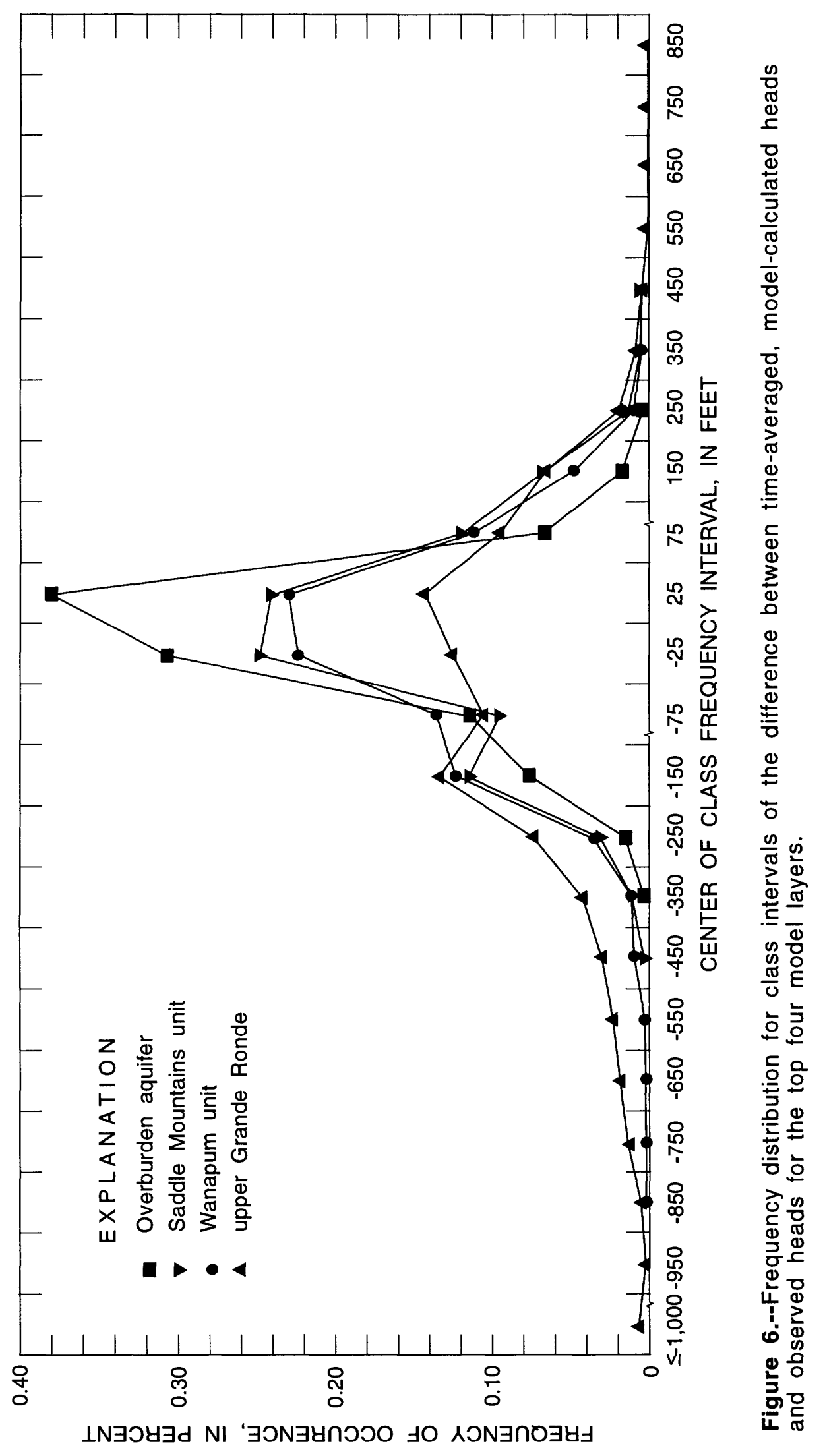


Most of the residuals are centered around $0.0 \mathrm{ft}$ and the distribution is approximately normal (fig. 6). The mean residuals for all cells, from layer 1 to 4 , are $-18,-14,-31$, and $-122 \mathrm{ft}$, respectively. A mean residual of 0.0 would indicate, on the average, about an equal number of positive and negative residuals of similar magnitude. The sign of the residual shows the model bias and, thus, the negative signs show that the model generally calculates lower-than-observed heads. Further, the residuals become larger with depth of burial and thickness of unit.

The mean absolute residual indicates the goodness-of-fit between the calculated and observed head surfaces. The mean absolute residuals for all cells, from layer 1 to 4 , are $46,72,81$, and $184 \mathrm{ft}$, respectively. As with the mean residual, the values increase with depth of burial of the study units and, correspondingly, are correlated to thickness; that is, the thicker the unit, the larger the residual. This is shown also in figure 6 by the flatter and larger spread of the frequency distribution for the older, thicker study units. For example, the calculated head surface for the Wanapum unit is, on the average, within about $80 \mathrm{ft}$ of the observed head surface, whereas the upper Grande Ronde head surface is, regionally, about $180 \mathrm{ft}$ from the observed surface.

The root-mean-square (RMS) residual approximates the error in the calculated heads. The RMS residuals for all cells, from layer 1 to 4 , are 71, 104, 124, and $292 \mathrm{ft}$, respectively. Although the RMS value generally is understood to be the relative error in simulated head, it is not an estimate of the error for any model cell. This is because of (1) paucity of data in some areas, (2) errors in interpretation of observed-head values for partially penetrating and composite wells, (3) areal variations in the magnitude and sign of the residuals, and (4) hydraulic head gradients. An example of (1) is that, in some areas with paucity of data, water-level configurations were not interpreted in the work of Bauer and others (1985), Whiteman (1986), and Lane and Whiteman (1989) but were interpreted in the gridding of hand-drawn contoured information for model construction and calibration. An example of (2) is that in some areas, the head control was measured heads in shallow, partially penetrating wells that are not representative of the vertically averaged heads. As an example of (3), figure 6 shows that nearly 70 percent of the calculated heads for the overburden aquifer cells are within $50 \mathrm{ft}$ of observed values and more than 70 percent of the calculated heads for the Saddle Mountains and Wanapum units are within $100 \mathrm{ft}$ of observed values. Additionally, throughout much of the flat-lying Palouse subprovince, the calculated heads are within $50 \mathrm{ft}$ of the observed heads, whereas, in steep terrain areas, the calculated heads are, generally, on the order of 100 to $150 \mathrm{ft}$ lower than observed. Last, as an example of (4), where the observed upper Grande Ronde heads are less than $1,500 \mathrm{ft}$, typically in locations of relatively small lateral head gradients, the mean residual is about $-55 \mathrm{ft}$, and where observed heads are more than 1,500 ft, typically uplands and steep terrain areas, the mean residual for the upper Grande Ronde is about $-125 \mathrm{ft}$. Thus, in areas with more complete head control and smaller lateral gradients, the model does a reasonable job of simulating the head surface, and in areas with little control and (or) large lateral head gradients, the model does worse. However, in many cases the areas of worse fit, typified by large downward vertical gradients, the interpreted, gridded head data were revised because the model appeared to calculate vertically averaged heads that are more representative of the layered system.

A comparison of selected, observed, and calculated water-level contours (on plate 9) shows that the model reasonably simulates the regional flow system. The agreement between the two sets of contours is good for the upper three model layers, but is not as good for the upper Grande Ronde layer. In that layer, the calculated heads are generally lower and calculated lateral gradients are generally smaller. As discussed earlier, the calculated distribution for this layer throughout much of the modeled area might be the best estimate, to date, of the true, vertically averaged, water-level configuration. Indeed, there were fewer than 350 Grande Ronde unit (noncomposite) data points, and most of the wells measured did not penetrate the average 2,000-ft thickness of that unit. Thus, the validity of those data for deriving gridded information at about 7,000 cells is in question.

Comparison of the model-calculated heads with observed point data for only those cells that had water-level observations (excluding composite well data) shows the mean absolute and RMS residuals to be 39/58,67/91, $88 / 142$, and $158 / 253 \mathrm{ft}$, for layer 1 to 4 , respectively. These values indicate how representative a calculated head is of the point data. The residuals are similar to those calculated for the gridded data for all cells, even though the point data represent less than 8 percent of the total active cells for any model layer. This indicates the reasonableness of the regional goodness-of-fit of the model-calculated heads. As was the case for all cells, the mean residual for each layer is negative in sign and increases with the average thickness (age) of the units. Similar to the comparison with gridded data described earlier, the mean residual for upper Grande Ronde cells with well 
data having heads less than $1,500 \mathrm{ft}$ was $-67 \mathrm{ft}$, whereas, with well data having heads greater than or equal to $1,500 \mathrm{ft}$, the mean residual was $-157 \mathrm{ft}$. In downward flow areas, which include a large part of the modeled region and all of the steep terrain areas, simulated heads are probably reasonable; that is, the calculated heads should be lower than the heads measured in a partially penetrating well.

The comparison of the difference between calculated and observed vertical gradients is difficult to assess. This is because (1) information is lost when gridding (averaging) observed data, (2) the calculated heads, being lower than observed in the older units, can give quite different gradients than the head gradient from observed data, and (3) the large variation in vertical gradients within and between units makes estimation of actual vertical gradients difficult to assess. Thus, vertical head changes (for which there are more data and which are more appropriate to discuss for this multiaquifer system) are described below.

Comparing gridded-observed and model-calculated areas of upward flow showed an excellent match. Also, within the upward flow areas, observed and model-calculated vertical head differences and gradients are nearly the same.

The mean and mean absolute vertical head changes between the overburden aquifer and the underlying unit were 67 and $80 \mathrm{ft}$ for gridded-observed conditions and 67 and $71 \mathrm{ft}$ for the time-averaged model. The model calculated smaller upward gradients in the upward flow areas and larger downward gradients in the Yakima Fold Belt. The mean difference between calculated and observed changes was about $9 \mathrm{ft}$ and the RMS residual was $181 \mathrm{ft}$. The larger RMS value is due to about 10 percent of the cells having much larger calculated downward gradients. For this layer, however, the mean absolute residual and median value were 84 and $-10 \mathrm{ft}$, respectively. About 50 percent of the calculated vertical head changes were within $40 \mathrm{ft}$ of the observed.

For the vertical changes between the Saddle Mountains unit and the underlying unit, the mean and mean absolute changes for gridded-observed data were 139 and $160 \mathrm{ft}$, and the means of the calculated changes were 130 and $140 \mathrm{ft}$. Similar to the overburden layer, the calculated downward gradients were larger in some areas (especially in areas with the largest observed downward gradients), and in the upward flow areas the gradients were smaller. The mean difference between calculated and observed was $21 \mathrm{ft}$, and the RMS and mean absolute residuals were 177 and $100 \mathrm{ft}$, respectively. The median difference was $2 \mathrm{ft}$, with 40 percent of the calculated head changes within $50 \mathrm{ft}$ of observed.

The mean and mean absolute vertical head changes between the Wanapum and upper Grande Ronde units were about 196 and $210 \mathrm{ft}$ for gridded-observed conditions and 253 and $259 \mathrm{ft}$ for the time-averaged model. The mean difference between calculated and observed changes was $65 \mathrm{ft}$, and the RMS and mean absolute residuals were 252 and $150 \mathrm{ft}$, respectively. The median difference was $6 \mathrm{ft}$, with 50 percent of the calculated values within about $80 \mathrm{ft}$ of observed and 70 percent of the values within about $150 \mathrm{ft}$.

These results show that, overall, the model calculates about the same gradient or head change as that observed. The calculated head differences are smaller for the top two layers and about $50 \mathrm{ft}$ larger for the Wanapum layer. Similarly, the calculated range of the vertical gradients was larger for the upper two layers, mainly because of the large calculated downward gradients at some cells, and was smaller for the Wanapum layer. The median differences between calculated and observed vertical head changes show only a small model bias. For the upper three model layers, the 20th-percentile difference between calculated and observed is about $-70 \mathrm{ft}$ ( 20 percent of the calculated vertical changes were less than the observed by $70 \mathrm{ft}$ or more). However, the 80th-percentile differences for the upper three model layers are about 40,85 , and $150 \mathrm{ft}$, respectively. Thus, underprediction of vertical gradients is about the same for each layer, and the model calculates successively larger vertical head changes than observed as one moves down into the aquifer system. 
In summary, the RMS head residual for each model layer approximates the error in calculated heads. The upper three model layers have RMS values of about $100 \mathrm{ft}$, with more than 70 percent of the values less than $100 \mathrm{ft}$. The upper Grande Ronde error estimate is larger, $292 \mathrm{ft}$, and the larger error values generally occur in either steep terrain areas or in areas with little or no head control information. The distribution of RMS errors shows that it is more representative of the steep terrain (large gradient) areas within the regional flow system and the error is smaller, more like the mean absolute residual, where lateral head gradients are smaller. Overall, the model reasonably simulates the regional flow system, but there are locally significant variations between observed and calculated heads (plate 9). 


\section{SPECIAL SIMULATION PROBLEMS AND SOLUTIONS}

Some problems arose during the calibration process that could not be resolved with parameter adjustments that were supported by data. Several of the problems already have been mentioned in previous sections. This section discusses in more detail some of the perplexing ones, the necessary parameter adjustments, and physical hypotheses regarding these adjustments.

\section{Vertical Head Gradient Problems}

The observed water levels, in general, exhibit downward gradients in successively deeper aquifer units throughout most of the aquifer system. Only close to major rivers and streams and locally at large pumping centers are the gradients upward. Moreover, the magnitude of the downward gradients is generally large in comparison with the magnitude of the upward gradients. Downward head differences of more than $400 \mathrm{ft}$ between basalt units occur throughout the study area, but upward head differences of more than $100 \mathrm{ft}$ are rare. A reasonable match with observed vertical gradients could be achieved in the upland areas using relatively small vertical conductances in the model. However, areas near major rivers, such as the Columbia, Snake, and Yakima Rivers, parts of which are located in synclines, had calculated upward vertical gradients of the same magnitude as the downward gradients of the uplands. Conversely, using relatively large vertical conductances in the model to match the observed lowland vertical head gradients, calculated vertical gradients in the upland areas were too small.

A hypothesis to account for the above differences was poor definition of the distribution and lithology of the interbed material. Using typical published values of vertical conductivities of similar interbed materials, vertical conductances were calculated from thicknesses of the interbeds and reasonable values of vertical conductances for basalt (see the "Vertical Hydraulic Conductance Per Unit Area" section for exact formulation). In practice, this method was difficult to apply because of the large, local variability of the lithology and thickness of the interbeds, and the large areas where no interbed data were available. The results of this effort only slightly improved calculated head gradients.

In order to achieve a reasonable vertical head gradient match, it became necessary to introduce spatial variation of vertical conductance that is not necessarily supported (or disputed) by available data. When vertical conductance beneath the major rivers was made sufficiently large (in addition to setting the stream-leakage coefficients sufficiently large) and vertical conductance over most of the remaining modeled area was not changed, improved vertical gradient matches were calculated. Thus, it appeared that where a river bed was observed to be in a particular basalt unit, it behaved as though it were connected nearly perfectly to the next lower basalt unit as well. Two hypotheses are presented here to explain such connection.

(1) Riverbeds probably are entrenched more deeply into the basalt layers than has been mapped. When bottoms and tops of units were mapped, outcrop and well logs were used for altitude control. Smooth structure contours were drawn using these controls. Thus, under major rivers where there is no control other than streambed altitude, it is almost certain that if the river was entrenched deeply into the basalt units, it would not have been mapped as such. The original assignment of river cells, therefore, probably was biased toward the upper units; thereby introducing a greater simulated impedance for discharge from lower units.

During Pleistocene time, there were enormous discharges down the Columbia and Snake Rivers from the breaching of prehistoric Lake Missoula in Montana and Lake Bonneville in Utah. These large flood volumes scoured and plucked the riverbeds, and then deposited alluvium to great depths. At Wallula Gap on the Columbia River, for example, just downstream of the confluence of the Columbia and Walla Walla Rivers, cobbly gravels more than $250 \mathrm{ft}$ thick are reported below the riverbed (Mackin, 1955).

(2) Rivers that cut across bedding planes only at scattered locations can increase greatly the "apparent vertical" connection between units. Many such localized cuts would not have been accounted for in this regional study. Impedence to discharge can be decreased greatly in such a situation because basalt $\mathrm{K}_{\mathrm{h}}$ can be several 
orders of magnitude greater than $\mathrm{K}_{\mathrm{z}}$. Therefore, there may be much less vertical flow to the rivers than has been conceptualized because ground water can discharge laterally to where the basalt layers are cut. Such a "bedrock topography" enhancement of vertical conductance would occur only in areas of shallow water levels (discharge areas). Thus, in upland areas, where the basalt strata may be dissected even more, localized cuts have little or no effect on vertical conductances because regional ground-water movement is downward and towards the large rivers.

The preceding discussion does not apply to the lowermost modeled layer, the lower Grande Ronde, the top of which is far beneath all rivers. The vertical conductance between the upper and lower Grande Ronde layers, for lack of any data, was calculated in the same manner as for that between the Wanapum unit and the upper Grande Ronde, giving smaller vertical conductance values than between the upper layers because of the greater thicknesses involved. However, adjustments of vertical conductance between the upper and lower Grande Ronde resulted in a good head match only when generally larger and nearly uniform values of vertical conductance than those estimated from equation 6 were used (see plate $7 \mathrm{~b}, \mathrm{c}$, and d). This may be attributed to the fact that there are few interbeds and saprolites between the Grande Ronde Basalt flows that would impede vertical ground-water flow, and (or) the depositional environment, fluidity, and volume of earlier basalt flows may have resulted in enhanced vertical ground-water flow.

For the tightly folded upland areas, vertical conductance between the Saddle Mountains and Wanapum units and between the Wanapum unit and the upper Grande Ronde is smaller than for most of the structurally less complex areas. Using median range values, the model could not sustain water levels in most of these areas. In fact, many cclls were calculated as desaturating in the upper unit. This structural relation between anticlines and small vertical conductance is not understood clearly. One hypothesis is that compression during folding disrupted and closed the vertical jointing spaces in the colonnade parts of the basalt flows. Physical evidence for this disruption and closure is observed in exposures of anticlines cut deeply by the Yakima River, a few miles upstream of the city of Yakima. The colonnade structure is barely recognizable in these exposures, whereas the colonnade is obvious in the more horizontal exposures of basalt flows.

Similarly, for the uplifted Blue Mountains, vertical conductance is reduced (compared with the flat-lying areas) between the upper and lower Grande Ronde layers. The lower conductance is probably because of the large number of faults in this uplifted area. Thus, it appears that anticlines, and areas that are highly faulted, have similar hydrologic effects on the movement of ground water.

\section{Lateral Head Gradient Problems}

Nearly everywhere on the plateau, water levels in the water-table aquifer parallel the land surface. Such topographic control suggests that the water-table aquifer is drained by rivers, streams, and even intermittent streams and coulees. Only in the low-lying areas near the center of the study area, where the water table is deeper, is this control lacking.

Strong topographic control was obtained in the model by assigning many drain and river cells. Initially these cells were assigned only along the larger perennial streams and rivers, and as a result, the model calculated heads that were too large in many areas. It became evident that more control was necessary, especially in the upland areas that receive large amounts of recharge, such as the south and west flanks of the Blue Mountains and the east slope of the Cascade Range. To test the need for additional control, a reduction (exceeding 60 percent) in recharge in large precipitation areas was used in the model. Results showed that the drains simply received less than observed baseflow and heads were still high. Thus, in order to prevent computation of heads higher than observed, it became necessary to use the drain or river functions for many cells containing a surface-water feature of any size. One alternative to prevent high computed heads was to increase lateral hydraulic conductivity to larger than median values in areas of large precipitation. Such coincidence of large precipitation and large conductivity is unlikely; this alternative was not pursued. In fact, heads lower than observed were computed in various upland areas that initially were assigned median conductivities and that receive relatively small amounts of precipitation, such as in the Yakima Fold Belt, eastern Horse Heaven Hills, Beezely Hills, and Frenchman Hills. This suggested that upland 
areas probably have smaller than median, rather than larger, hydraulic conductivities. Thus, in general, conductivities in the uplands were made sufficiently small to adequately match observed heads in areas of low recharge, and these values were assumed to be applicable to other upland areas that receive more recharge.

Whereas specific-capacity data generally do not show any consistent correlation between upland areas and smaller (or larger) hydraulic conductivity, such data are scarce in the uplands. In the few areas where there are such data, such as in a small part of Horse Heaven Hills, specific-capacity data indicate that conductivities are smaller toward the crest of the anticline. A plausible argument is presented here in support of smaller upland conductivities based on the fact that upland areas of the Columbia Plateau are known to have numerous faults.

Because lateral ground-water flow in basalts is predominantly along the rubbly interflow zones, which typically occupy only 5 to 10 percent of a basalt flow thickness, even minor offsets of the basalt strata would tend to impede lateral flow. On a regional scale, an effectively smaller conductivity would be the consequence of such faulting. Locally, however, the permeability is intact between fault zones and well pumping tests may not show such smaller, regional-scale values unless conducted on a long-term basis with sufficient pumpage rates to lower water levels at the faults (boundary effects). Thus, a regional ground-water model with cells larger than fault spacing can only simulate flow through a faulted area using smaller hydraulic conductivities.

The approximation of the Dupuit-Forchheimer formulation for evaluating equivalent stream- and drain-leakage coefficients gave reasonable results, but needed further adjustments. In general, increasing the coefficients improved the calculated-to-observed head match and there appeared to be no upper coefficient-value where calculated-to-observed head match actually became worse. This improvement probably results from the conceptual formulation of the drain function, an impeding layer between the aquifer and surface water, generally not applying in this study area. The leakage coefficients are actually a function of head near the drain as well as a function of aquifer conductivity and thickness. Thus, for equivalent aquifers and streambeds, the coefficients are location dependent because of varying amounts of upgradient inflow, and not because of the hydraulic characteristics of the aquifers or streambeds. Future additional inflow may not be simulated properly because coefficients calibrated to preexisting conditions may not be large enough to simulate actual discharge amounts. In other words, the coefficient would need to be larger if additional inflow causes higher head in the vicinity of a drain.

\section{$\underline{\text { Area-Specific Problems }}$}

There are certain specific areas where unusual problems were encountered during the calibration process.

(1) Big Bend area: This area lies north of Pasco, Wash., and encompasses the area between the Snake and Columbia Rivers to as far north as about $46.5^{\circ}$ latitude (fig. 1). Ground-water flow in all four basalt units in this area is generally southwestward toward discharge areas along the Columbia and Snake Rivers. Calculated heads under a wide range of reasonable values of $\mathrm{K}_{\mathrm{h}}$ and $\mathrm{K}_{\mathrm{z}}$ were too high in the Wanapum and Grande Ronde units, especially in the Grande Ronde unit. The only reasonable solution found was to assign small lateral hydraulic conductivities along an east-west-trending strip just upgradient of this area. Using this strip of small conductivities, the model calculated an associated strip or zone of large lateral hydraulic gradients (these calculated gradients correspond to observed gradients). To the northeast (upgradient) or the southwest (downgradient) of this low conductivity "strip," lateral head gradients in the Wanapum and Grande Ronde units are considerably smaller. The physical reason for this anomaly in a relatively flatlying region is not known. The strip corresponds to an eastward extension of the Saddle Mountains anticline into the subsurface. Thus, the deeper, older basalts might be folded and faulted along this strip and later covered by the younger Wanapum Basalt flows, so that there is now no surficial expression of such structure. However, because the Saddle Mountains were being uplifted during and after Saddle Mountains time, it is more likely that even the younger Wanapum Basalt along the strip would have been displaced as well. Perhaps such faulting has not been mapped because displacements are small and outcrops scarce. As was mentioned previously, only slight vertical displacements of basalt flows can result in reduced regional hydraulic conductivities. 
(2) Odessa-Lind pumping center: This roughly rectangular area lies south of Crab Creek, west of Cow Creek, east of the East Low Canal, and north of Lind Coulee (fig. 1). During the initial time-averaged simulations, a large number of Wanapum unit cells desaturated in this area, regardless of reasonable hydraulic conductivities and vertical conductance adjustments. Ground-water pumpage from the surficial Wanapum unit is simply too large to be supplied by lateral or upward ground-water inflow. In this area, recharge was increased from amounts estimated from the deep percolation model. The most likely source of such additional recharge is the surface water that is present at times in the coulees that cross this area. The water table is below the bottom of these coulees, and therefore they do not drain the Wanapum unit. In fact, downgradient flexures of the Wanapum unit water-level contours beneath some of the larger coulees suggest that they are recharging the water-table aquifer. Moreover, crest-stage streamflow data for several of these coulees show that for short periods there is a large potential for recharge. Providence Coulee, for example, flowed at the rates of $2,160,650$, and $522 \mathrm{ft}^{3} / \mathrm{s}$, during 1956,1969, and 1970, respectively (Williams and Pearson, 1985). Actual recharge amounts derived from the streamflow in the coulees could not be estimated, so the smallest uniform amount of recharge, which would keep most cells in this area satur.ted during simulations, was added along the coulee courses.

(3) Moses Coulee: This coulee, second in size only to Grande Coulee, cuts deeply into the Grande Ronde Basalt on the Waterville Plateau, in Douglas County. The Waterville Plateau is bounded on the west and north by the Columbia River, on the east by Grande Coulee and on the south by Beezely Hills (fig. 1). Moses Coulee appears to drain the Grande Ronde Basalt over its entire length, yet most of its upper reach contains no perennial stream. However, Jamison Lake, which is located in the upper reach and lies in the coulee bottom, has no outlet and yet contains fresh water. The drainage for a large part of Moses Coulee is included in Douglas Creek basin. The model calculates about $37 \mathrm{ft}^{3} / \mathrm{s}$ of net discharge within this basin. Streamflow records indicate the flow is much smaller. Additionally, the model calculates about $10 \mathrm{ft}^{3} / \mathrm{s}$ of ground-water discharge to the lower part of Moses Coulee.

When recharge on the Waterville Plateau is reduced so that calculated discharge is more comparable to observed or estimated streamflow, calculated water levels are too low. This occurs using reasonable values of lateral hydraulic conductivity. Vertical conductance is not an issue because only the upper Grande Ronde is modeled in this area; the Wanapum unit is present, but only in small, discontinuous areas that are not included in the model as the Wanapum unit but are considered part of the upper Grande Ronde. Had the Waterville Plateau been divided into two layers for model simulation, this division would have permitted more ground-water underflow discharging to the Columbia River. However, calculated ground-water discharge to Moses Coulee and Douglas Creek probably would still have been larger than observed. Given the size of Jamison Lake, there may be ground-water outflow through the highly conductive alluvium lying in the coulee bottom. Therefore, ground-water discharge to Moses Coulee may be primarily into the alluvium. This water, in turn, flows in the alluvium to the Columbia River at the coulee's mouth.

(4) Peripheral and upland areas: For many high-altitude areas, simulated heads are considerably lower than observed or estimated heads, even after extreme downward adjustments of lateral hydraulic conductivities and vertical conductances. Most observed water levels in the uplands are from shallow domestic wells that penetrate only the uppermost part of a basalt unit. Such water levels are not representative of the vertically averaged values of head for the unit, unless the unit is relatively thin. In fact, downward vertical gradients are observed virtually everywhere in the uplands. For example, water levels in a test well, drilled on the crest of Rattlesnake Mountain within the Yakima Fold Belt (Raymond and Tillson, 1968), show a downward gradient of approximately $830 \mathrm{ft}$ within approximately $3,200 \mathrm{ft}$ of thickness of the Grande Ronde unit. Thus, if representative water-level data were not available and reasonable values of lateral hydraulic conductivity and vertical conductance were used, simulated heads lower than observed were assumed to be reasonable in the uplands.

Additionally, many peripheral, upland cells of the uppermost unit would desaturate during simulation. This desaturation usually occurred in areas where the unit was thin and (or) recharge was small. For example, the entire crest of Saddle Mountains east of the Columbia River, which is in a low recharge area, desaturated. 
With no water-level data or any other indications of saturation, such as ground-water pumpage, these desaturated cells generally were accepted, despite the original estimates of water levels presented in earlier reports (Bauer and others, 1985; Whiteman, 1986; and Lane and Whiteman, 1989).

\section{Numerical Problems, Model Limitations, and Sensitivity}

The goal of the construction of the ground-water flow model was to provide a means of projecting the aquifer's regional response to ground-water development and provide information for interpreting the regional ground-water flow system, the relations among the components of the flow system, and for assessing the conceptual model of ground-water flow. The model also was to be used to test hypotheses on how the system operates on a regional scale. However, local variations in hydraulic characteristics and aquifer geometry caused numerical instability resulting from an ill-conditioned matrix (the diagonal of the matrix was not necessarily dominant). As a result, the regional distribution of parameters and calculated heads was dependent on local distributions. In addition, local changes in parameters or stresses could propagate numerical instabilities over many miles in the model, to areas hydrologically isolated. This aspect was aggravated further because locally, areas such as the small synclinal valleys in the Yakima Fold Belt were desaturating during simulation. These areas of intensive ground-water development are important with respect to water-resource availability. Last, the SIP module used to solve the finite-difference equations is an iterative solver. Using SIP, especially under some of the conditions described above, can result in a slow convergence to a solution. Solution convergence can be improved with proper choices of the model-input iteration parameters, the main parameter being WSEED. Although initial conditions are not needed when solving the ground-water flow equations without the time-dependent term, the iterative solver requires some initial condition from which to start calculations. The initial values chosen generally should not affect the final solution, however, these values can affect both the convergence and stability of the solution process.

The solution to the problem of instability was twofold. The first included detailed analyses of the aquifer-system geometry, water-budget components, and water levels within these areas. These analyses provided the basis for adjustments of hydraulic characteristics and structure contours. Numerical stability and more accurate results in certain localized areas made the model 'better behaved' numerically on a regional scale. For example, the number of iterations needed for solution closure, the head changes between iterations, and the number of cells desaturating were reduced.

The second solution was the continuing analysis and adjustment of the increment, which is added to the gridded-observed heads in order to obtain the initial or starting heads, and the numerical iteration parameters. The model is sensitive to both of these factors. As a final set of model iteration parameters was derived, the model became more stable numerically, and the solution closure was improved and was reached with fewer iterations. The final value for WSEED was 0.0267 (maximum iteration parameter equal to 0.9733 ) and there are seven iteration parameters. Correspondingly, the head increment added to the gridded-observed heads is about $200 \mathrm{ft}$, although it does vary.

Modified component sensitivities (McCuen and Snyder, 1986) were calculated after the model was calibrated in order to provide a simple method for studying the effects of changes in model variables on simulated heads. This calculation method also allows for an additional assessment of how well the model simulates the physical system and, to some extent, allows for assessment of the sensitivity of the model to hydrologic variables. Standard component sensitivities are calculated by dividing the head change from the calibrated model at a model cell by the change in the variable at that cell, whereas the modified component sensitivities are based only on the head change. This calculation allows for a comparison of head changes, a more physically based measure. The head changes, in turn, can be compared with the observed and calculated water-level surfaces and with the calibration results.

Analysis of the calculated head changes also shows how much the system is affected by changes in hydrologic variables and will indicate if the effects are physically reasonable. If the effects are reasonable, especially on a regional basis, then confidence in the reliability of the model is increased. 
The component sensitivities were calculated on the basis of changes in four variables: lateral hydraulic conductivity, vertical hydraulic conductance, recharge, and pumpage. Lateral hydraulic conductivity and vertical hydraulic conductance were changed by \pm 20 percent, pumpage (excluding the change in storage) by \pm 25 percent, and recharge by -15 and +25 percent.

An interesting result, indicated by the component sensitivities (table 6), is that the head changes are small, generally less than one-half of the water-level contour interval used to map the observed data, and less than the mean absolute residuals of the calibrated model. Previously, the numerical stability of the model and the importance of deriving a reasonable distribution of variables was discussed. The component sensitivities indicate that once reasonable distributions are established, the model is not affected greatly by regional changes in those distributions (the relations between the water-budget components and the regional ground-water flow system remained virtually the same throughout most of the modeled region for the sensitivity simulations). Therefore, the model is affected more by local changes in variables than by regional changes.

The information in table 6 further illustrates several important aspects of the model. These aspects are (1) the effects of both increasing and decreasing hydraulic characteristics and pumpage increase with depth in the aquifer system; (2) the time-averaged model is affected more than the steady-state model for the top two layers, less affected for layer 3, and variably affected for layers 4 and 5; (3) effects of decreasing hydraulic characteristics are greater than those of increasing it; (4) for at least 50 percent of the model cells, most head changes generally are small; (5) recharge appears to be a major hydrologic control on the system; and (6) effects of decreasing pumpage are larger than effects of increasing pumpage. The above results are compatible with the real system and, thus, indicate that the model simulates the physical system. For example, the calculated changes in head for the simulations with a decrease in recharge and pumpage for current conditions (table 6) are in accordance with the magnitude of the changes in those water-budget components (about $1,500 \mathrm{ft}^{3} / \mathrm{s}$ and $300 \mathrm{ft}^{3} / \mathrm{s}$, respectively).

Similarly, although pumpage from the overburden aquifer is about 25 percent of the total pumpage, its head change was the smallest for the simulations with increased and decreased pumpage. This relation corresponds with the physical system; most of the overburden pumpage is in areas of extensive surface-water irrigation and, thus, water levels would remain near land surface under most pumping rates. Because ground-water movement in the deeper units is controlled partly by the quantity of water they receive from other units and throughout most of the central plateau, discharge from the deeper units is controlled by the major streams; the effects of changing the quantity of water moving in the aquifer system by increasing or decreasing the hydraulic characteristics should increase with depth. This concept is illustrated clearly by the information in table 6 . For example, in decreasing the vertical conductance, heads should rise in the upper units and decline in the deeper units and the rises would be moderated because the heads in the upper units are generally near land surface and drains would moderate the rises. Additionally, although heads in the deeper units (especially layer 5) generally would decline, it would be expected that the heads in the deeper units along the regional discharge area near the confluence of the Columbia and Snake Rivers would rise. These rises would occur because the units in that area are more confined than elsewhere, and vertical ground-water movement would be impeded more. The decile information (table 6) indicates that the model simulates this aspect of the physical system.

As a result of the above analysis and considering the uncertainties in hydraulic characteristics, potential for climatic changes, and variations in agricultural practices, the construction of a transient regional model for the purpose of making regional projections over time probably is not appropriate. However, because the calibrated model adequately describes the regional flow system, steady-state projections made with the model are assumed to be appropriate. The limitations on these projections are local in nature. One could not deduce, for example, that the water level for any particular model cell would be at some altitude calculated in a projection, or that the Columbia River would gain an additional $100 \mathrm{ft}^{3} / \mathrm{s}$. However, differences between the results of the calibrated models and the results of a steady-state projection can be compared in order to describe the magnitude of changes in water-level or water-budget components. For example, comparing differences, water-level rises or declines on the order of $10 \mathrm{ft}$ or more that would result from a projection scenario could be estimated for an area. The area discussed might represent 20 to $100 \mathrm{mi}^{2}$ but generally should be the size of at least a few cells. Thus, absolute water-level altitudes cannot be predicted but changes in both water-level and water-budget components can be. 


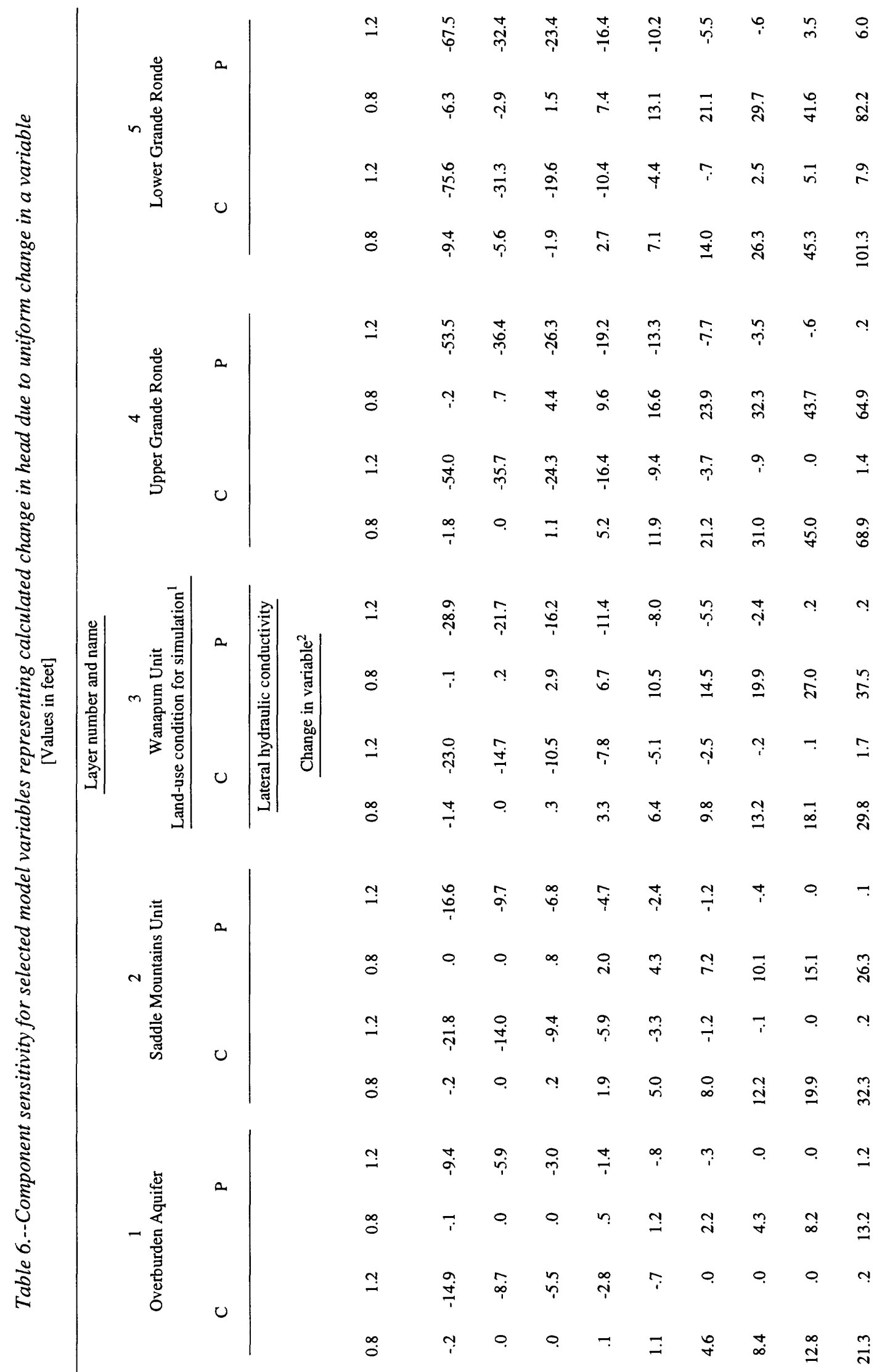

离它总这递

유 8 요요 


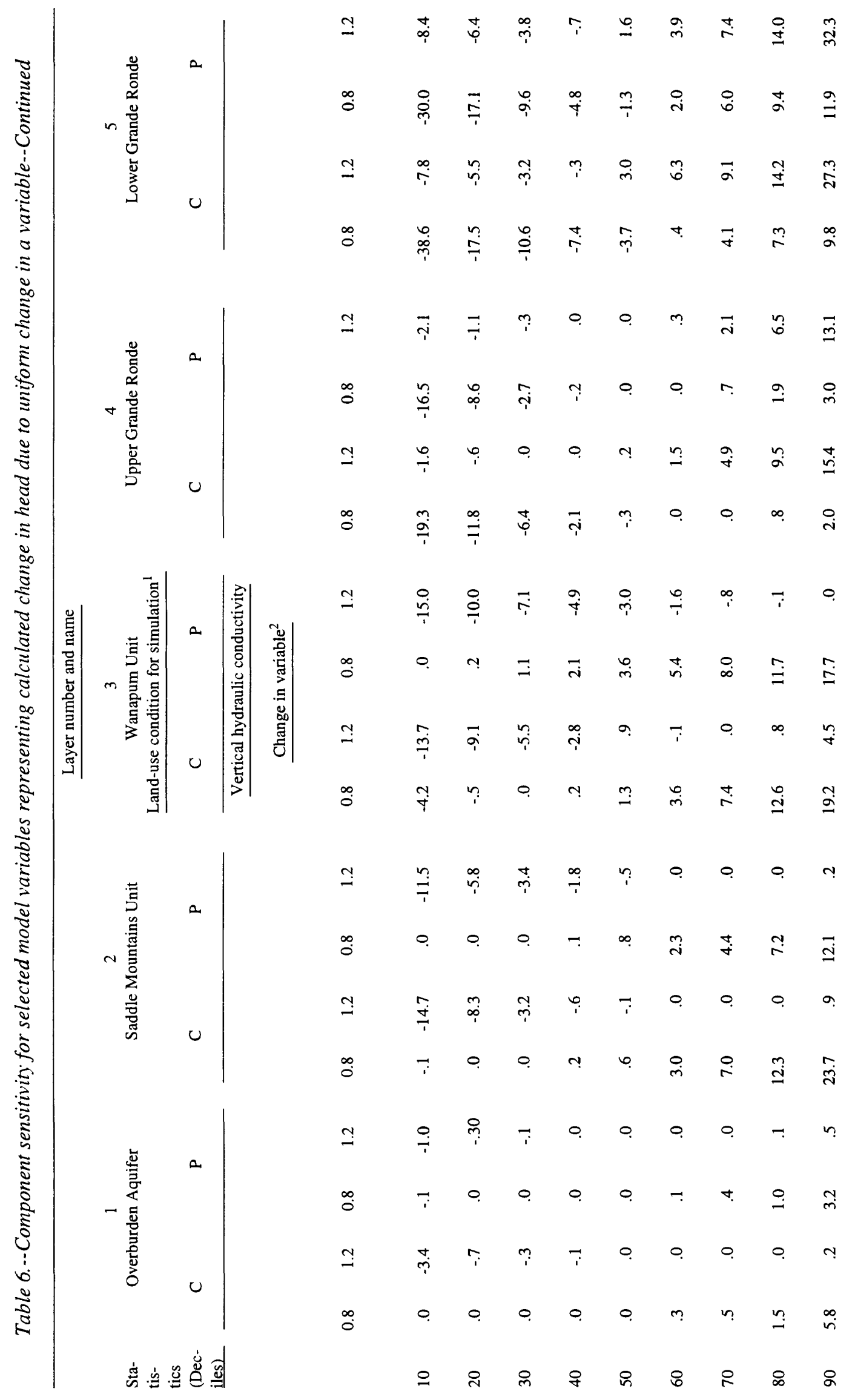




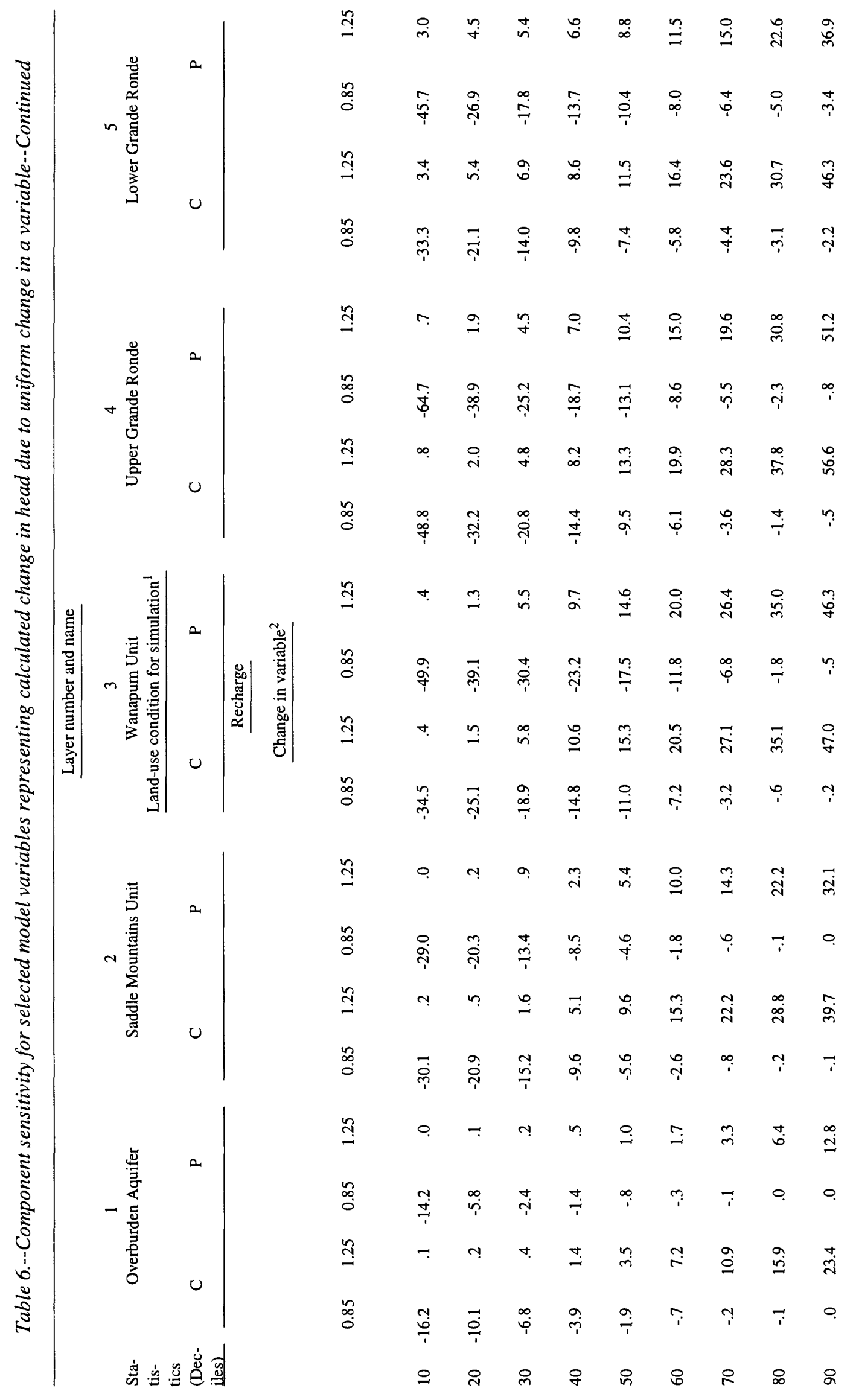




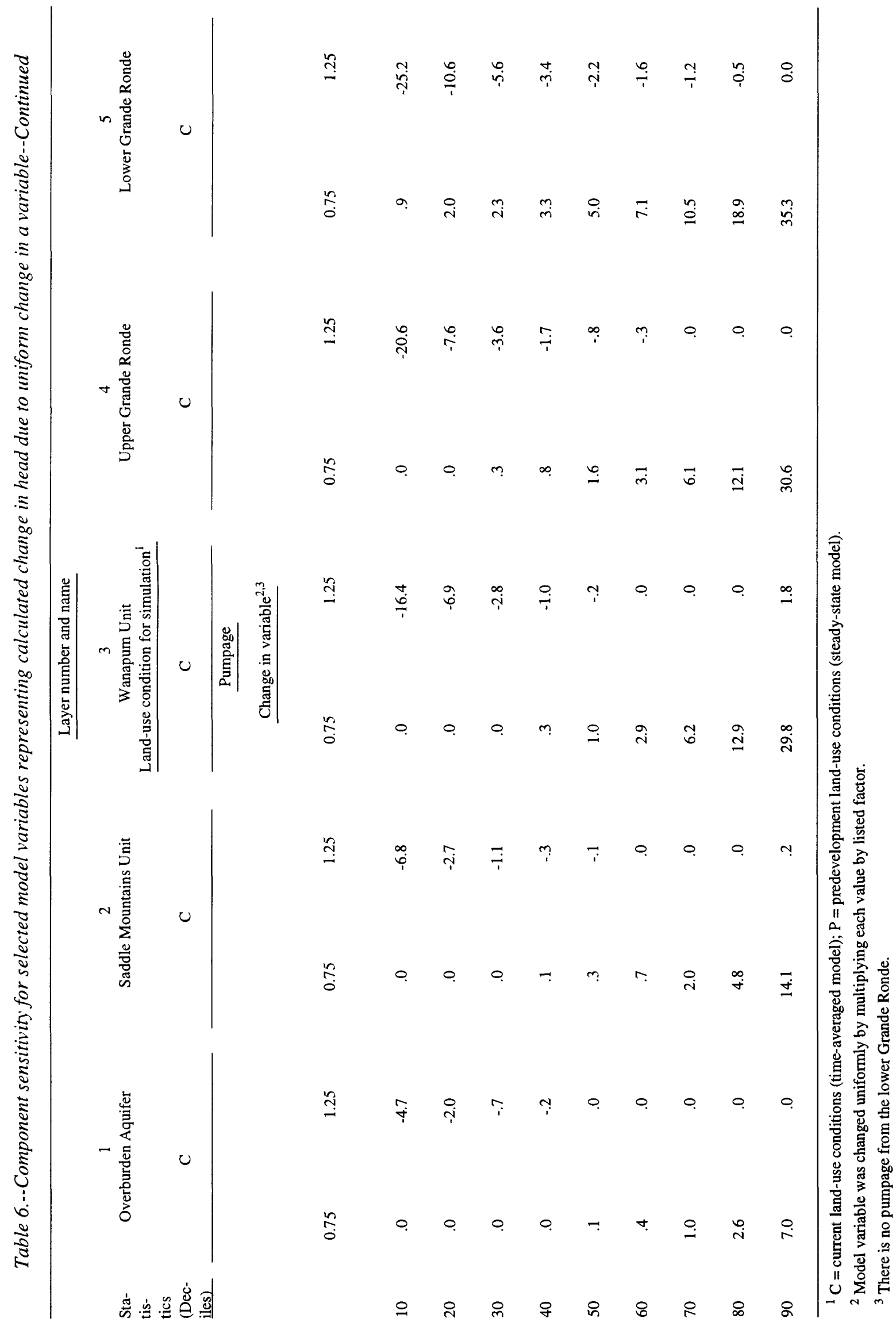


Areas of potential desaturation-saturation also can be described tentatively through model projections. Conclusions drawn for upland areas would have a larger potential of being in error than those for other areas, especially with respect to desaturation of cells. For example, if one or more cells desaturate during a projection simulation because of numerical errors, then the next unit down automatically would become a water-table aquifer and receive the recharge for those cells. Comparison of calculated heads then would show large declines in the unit that went dry and large water-level rises in the next unit down. Thus, in the numerically sensitive upland areas, especially those with small recharge, care must be taken in interpretation of model results. Additionally, the regional model can be used to define boundary conditions for smaller, subregional scale models. Last, it should be reiterated that temporal variations and histories were not addressed in this study and cannot be addressed with the model. 


\section{DISCUSSION OF THE REGIONAL FLOW SYSTEM ON THE BASIS OF MODEL SIMULATIONS}

The following subsections describe the hydrology of the regional aquifer system by presenting the results of the predevelopment and time-averaged simulations, respectively. The changes in the flow system caused by water-development practices then are described. General hydrologic concepts learned about the regional aquifer operation are discussed throughout.

The discussions in the first two subsections first describe the regional water balance; next, flow within each unit is discussed; and last, flow between units is discussed. For the time-averaged simulation, discharge from the aquifer system also is described for selected basins and stream reaches. The discussions generally emphasize the Wanapum and Grande Ronde units because they make up about 98 percent of the volume of the aquifer system.

Consistent terminology is used in the following sections. Recharge refers to the long-term, average estimates from direct precipitation and irrigation practices, as described previously. This terminology will distinguish this water-budget component from ground water moving between units and stream leakage to the aquifer system. Local flow systems and short flow paths refer to lengths of scales less than about $10 \mathrm{mi}$, intermediate flow systems and flow paths refer to lengths ranging from about 10 to $30 \mathrm{mi}$, and long or regional length flow paths generally refer to lengths longer than about $30 \mathrm{mi}$. Local discharge is the model-calculated discharge to seepage faces (GHBs) and drains. Conceptually, most of the local flow occurs in the peripheral and upland areas and the overburden aquifer, whereas intermediate flow paths are found in those areas and also within the regional flow system. A diagrammatic section showing idealized ground-water flow patterns and the concept of local to regional flow systems is shown in figure 7 .

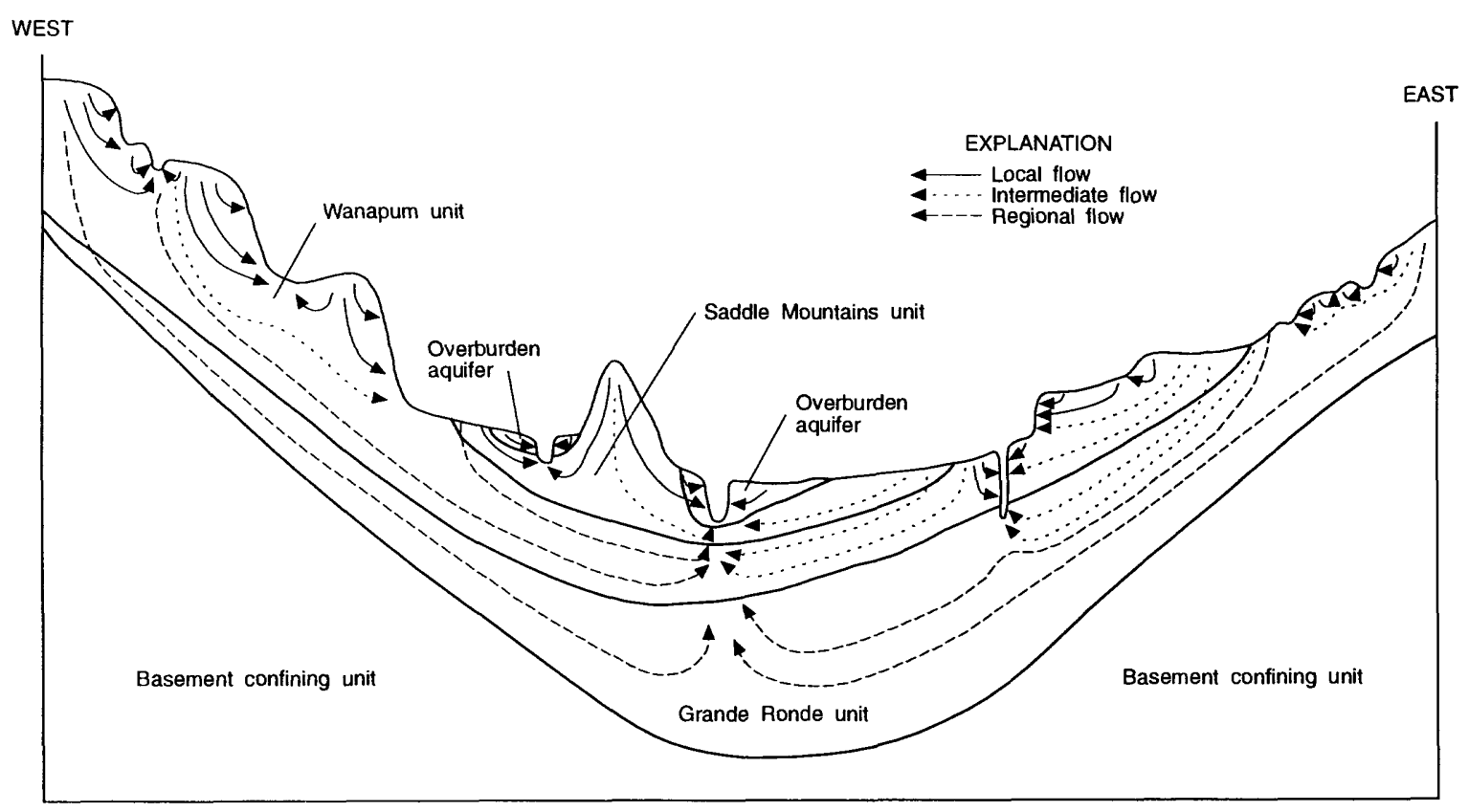

Figure 7.--Generalized diagrammatic hydrogeologic section showing idealized groundwater flow and the concept of local, intermediate, and regional flow systems. 
Recharge and discharge occur throughout much of the area, and thus the terms recharge area and discharge area are not used. However, long flow paths generally terminate within certain areas on the plateau. These areas overlie that part of the aquifer described as the "regional discharge area." This area is typically where the upper Grande Ronde has higher heads than overlying units, where the sodium concentration (which increases with ground-water residence time; Steinkampf, 1989) in that unit is largest, and where all or most of the units in a vertical section have flow paths that terminate. This area generally is located in the lowest part of the Columbia Plateau and is in proximity to the major streams/drains within the study area: the Columbia, Snake, Yakima, Deschutes, and John Day Rivers.

\section{Predevelopment Conditions}

The calculated water budget of the regional aquifer system for the predevelopment simulation is presented in table 7; the calculated water budget for each layer is presented in tabular form (table 8) and in a schematic diagram (fig. 8), and the calculated discharge from the aquifer system is shown on plate 8d. Recharge to the ground-water system under predevelopment land-use conditions is shown on plate $4 \mathrm{c}$.

Table 7.--Calculated water budget for the predevelopment and time-averaged simulations for the regional aquifer system

[Values in cubic feet per second]

\begin{tabular}{lccr}
\hline Water-budget component & $\begin{array}{c}\text { Predevelopment } \\
\text { simulation (P) }\end{array}$ & $\begin{array}{l}\text { Time-averaged } \\
\text { simulation (TA) }\end{array}$ & $\begin{array}{c}\text { Difference } \\
\text { (TA-P) }\end{array}$ \\
\hline Recharge & $6,566.5$ & $10,205.0$ & $3,638.5$ \\
Leakage from rivers & 553.6 & 556.7 & 3.1 \\
Change in storage & .0 & 186.6 & 186.6 \\
TOTAL IN & $7,120.1$ & $10,948.3$ & $3,828.2$ \\
Leakage to rivers & $2,753.9$ & $3,804.5$ & $1,050.6$ \\
Leakage to drains & $3,944.8$ & $5,595.5$ & $1,650.7$ \\
Leakage to seepage faces & 425.5 & 422.6 & -2.9 \\
Pumpage & .0 & $1,134.7$ & $1,134.7$ \\
& & & $3,833.1$ \\
TOTAL OUT & $7,124.2$ & $10,957.3$ & \\
\hline
\end{tabular}

Of the approximately $33,000 \mathrm{ft}^{3} / \mathrm{s}$ of precipitation (the average amount for the 22 -year period of 1956-77) that falls within the ground-water model boundaries, about $6,570 \mathrm{ft}^{3} / \mathrm{s}(2.72 \mathrm{in} / \mathrm{yr})$ becomes ground-water recharge. About $119 \mathrm{ft}^{3} / \mathrm{s}, 0.56 \mathrm{in} / \mathrm{yr}$, (2 percent) enters the overburden aquifer, $133 \mathrm{ft}^{3} / \mathrm{s}, 0.59 \mathrm{in} / \mathrm{yr}$, (2 percent) enters the Saddle Mountains unit, $2,185 \mathrm{ft}^{3} / \mathrm{s}, 2.0 \mathrm{in} / \mathrm{yr}$, (34 percent) enters the Wanapum unit, and $4,131 \mathrm{ft}^{3} / \mathrm{s}, 4.7 \mathrm{in} / \mathrm{yr},(62$ percent) enters the upper Grande Ronde. Much of this recharging water (plate 4c) follows short flow paths within local flow systems and discharges to smaller streams and as seeps and springs along canyon and coulee walls (fig. 7 and plate $8 \mathrm{~d}$ ). For example, for model cells receiving more than about $3 \mathrm{in} / \mathrm{yr}$ of recharge, about 25 percent discharges locally, whereas for cells receiving less than about $3 \mathrm{in} / \mathrm{yr}$ and where there are no major rivers draining the regional system, less than 5 percent of the recharge discharges locally. Typically, some ground water moving along intermediate flow paths intermingles with water of short flow paths to become part of the local discharge. 
Table 8.--Calculated water budget for the predevelopment and time-averaged simulations for the model layers [Values in cubic feet per second]

\begin{tabular}{|c|c|c|c|c|c|c|c|c|c|c|}
\hline \multirow{2}{*}{$\begin{array}{l}\text { Water- } \\
\text { budget } \\
\text { component }\end{array}$} & \multicolumn{5}{|c|}{$\begin{array}{l}\text { Predevelopment simulation } \\
\text { Layer }^{1}\end{array}$} & \multicolumn{5}{|c|}{$\begin{array}{c}\text { Time-averaged simulation } \\
\text { Layer }^{1}\end{array}$} \\
\hline & 1 & 2 & 3 & 4 & 5 & 1 & 2 & 3 & 4 & 5 \\
\hline Recharge & 119.3 & 132.6 & $2,184.7$ & $4,131.1$ & 0.0 & $3,202.4$ & 576.7 & $2,267.8$ & $4,160.6$ & 0.0 \\
\hline Leakage from rivers & 452.3 & 11.5 & 45.0 & 44.8 & .0 & 407.0 & 8.7 & 69.5 & 71.5 & .0 \\
\hline $\begin{array}{l}\text { Leakage from over- } \\
\text { lying layers }\end{array}$ & .0 & 25.9 & 137.1 & 730.7 & 421.4 & .0 & 224.6 & 574.6 & 936.4 & 423.1 \\
\hline $\begin{array}{l}\text { Leakage from under- } \\
\text { lying layers }\end{array}$ & 578.2 & 503.0 & 708.1 & 423.0 & .0 & 733.8 & 560.9 & 685.4 & 425.8 & .0 \\
\hline Change in storage & .0 & .0 & .0 & .0 & .0 & .0 & 11.7 & 111.8 & 63.1 & .0 \\
\hline TOTAL IN & $1,149.8$ & 673.0 & $3,074.9$ & $5,329.6$ & 421.4 & $4,343.2$ & $1,382.6$ & $3,709.1$ & $5,657.4$ & 423.1 \\
\hline Leakage to rivers & 912.2 & 180.3 & 522.4 & $1,139.0$ & .0 & $1,882.5$ & 274.9 & 531.4 & $1,115.8$ & .0 \\
\hline Leakage to drains & 148.4 & 29.9 & 877.5 & $2,889.1$ & .0 & $1,670.1$ & 225.2 & 812.3 & $2,888.5$ & .0 \\
\hline Leakage to GHBs & 13.9 & 1.6 & 329.0 & 80.9 & .0 & 16.2 & 14.4 & 312.2 & 79.8 & .0 \\
\hline $\begin{array}{l}\text { Leakage to over- } \\
\text { lying layers }\end{array}$ & .0 & 369.1 & 620.2 & 800.0 & 423.0 & .0 & 503.9 & 685.6 & 790.5 & 425.8 \\
\hline $\begin{array}{l}\text { Leakage to under- } \\
\text { lying layers }\end{array}$ & 81.5 & 88.5 & 723.6 & 421.4 & .0 & 499.9 & 320.8 & 914.9 & 423.1 & .0 \\
\hline Pumpage & .0 & .0 & .0 & .0 & .0 & 285.1 & 39.7 & 449.2 & 360.8 & .0 \\
\hline TOTAL OUT & $1,156.0$ & 669.4 & $3,072.7$ & $5,330.4$ & 423.0 & $4,353.8$ & $1,378.9$ & $3,705.6$ & $5,658.5$ & 425.8 \\
\hline
\end{tabular}

${ }^{1}$ Layers identified in figure 11.

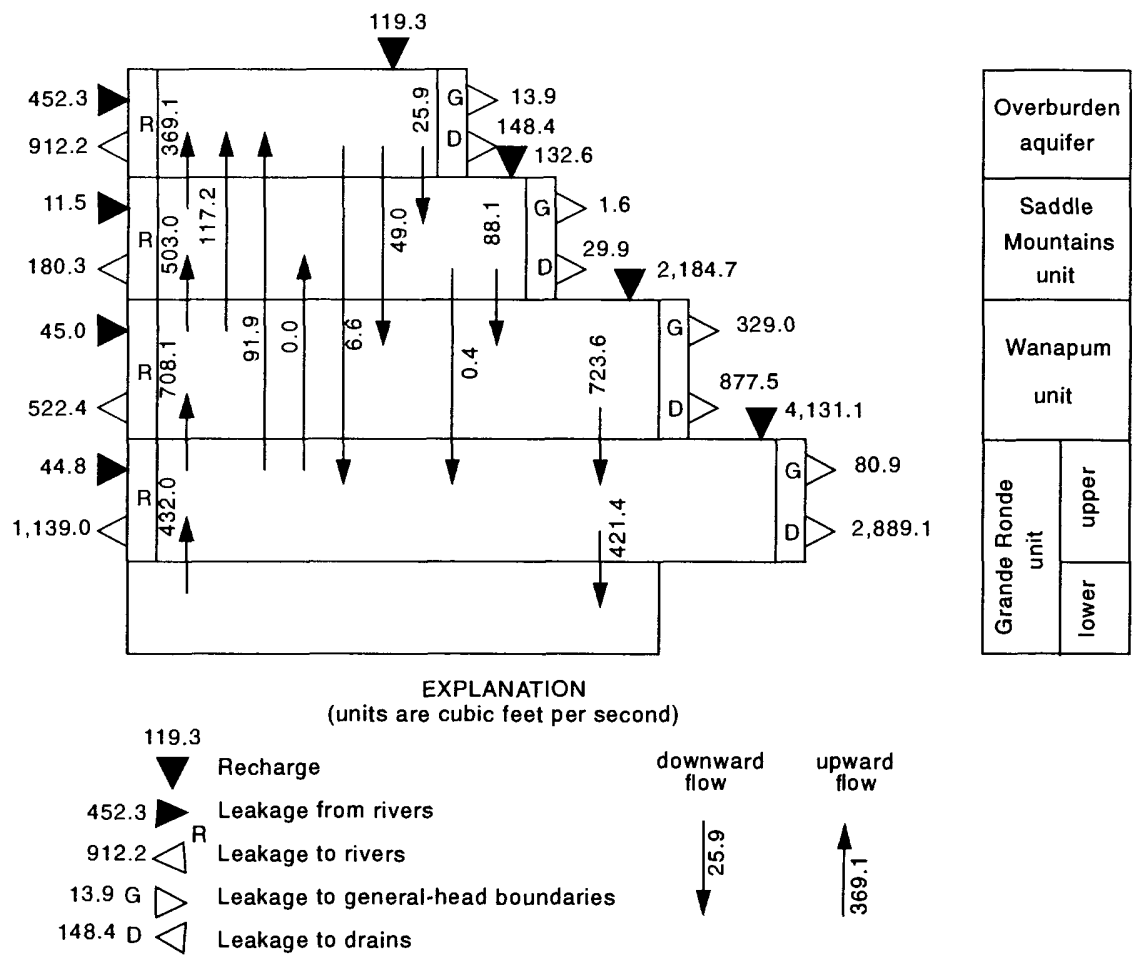

Figure 8.--Schematic diagram showing the model-calculated predevelopment (1850's) water buget. 
Local discharge from the overburden aquifer is about $162 \mathrm{ft}^{3} / \mathrm{s}$ (136 percent of its recharge) and about $912 \mathrm{ft}^{3} / \mathrm{s}$ discharges to the major streams. About 50 percent of the overburden discharge is flow from underlying basalt units, and about 40 percent is leakage from rivers. The local discharge from the Saddle Mountains unit is about $31 \mathrm{ft}^{3} / \mathrm{s}$ (24 percent of its recharge) and about $180 \mathrm{ft}^{3} / \mathrm{s}$ discharges to the Columbia, Snake, and Yakima Rivers. About $72 \mathrm{ft}^{3} / \mathrm{s}$ of the Saddle Mountains discharge is water from the overburden aquifer and the underlying basalts. The local discharge from the Wanapum unit is about $1,207 \mathrm{ft}^{3} / \mathrm{s}$ (55 percent of its recharge) and about $520 \mathrm{ft}^{3} / \mathrm{s}$ discharges to the major streams. Of this discharge, $840 \mathrm{ft}^{3} / \mathrm{s}$ is ground water from other units. About $2,970 \mathrm{ft}^{3} / \mathrm{s} \mathrm{of}$ ground water discharges locally from the upper Grande Ronde (72 percent of its recharge), and an additional $1,139 \mathrm{ft}^{3} / \mathrm{s}$ discharges to the major streams; about 10 percent of this discharge is from the lower Grande Ronde. There is no discharge from the aquifer system from the lower Grande Ronde; it receives and gives water solely to the upper Grande Ronde. About $420 \mathrm{ft}^{3} / \mathrm{s}$ discharges locally from the aquifer system in relatively short flow paths, about $3,950 \mathrm{ft}^{3} / \mathrm{s}$ discharges along combined, short to intermediate flow paths, and about $2,200 \mathrm{ft}^{3} / \mathrm{s} \mathrm{discharges} \mathrm{at} \mathrm{or}$ near the regional discharge area.

Prior to the introduction of water-development practices, the saturated part of the overburden aquifer covered about $2,910 \mathrm{mi}^{2}$. Although the overburden aquifer had a small extent and received only a small part of the recharge, it is hydrologically important. Thin sections, large hydraulic conductivity, and small disconnected areas of occurrence of the overburden aquifer result in short flow paths along which water is gained and lost readily from the upper and lower surfaces of the aquifer. The overburden aquifer transmits water mainly from the basalt units to the major rivers, and thus receives more water from other units than it receives from recharge and is, therefore, a hydrologically "active" unit.

The Saddle Mountains unit covers about $4,910 \mathrm{mi}^{2}$ or 15 percent of the modeled area, much of which either underlies or is near the regional discharge area. In the Yakima Fold Belt, the flow paths are short, from topographic/ structural highs to rivers along intervening valleys. In this area, about 15 percent of the unit was unsaturated during predevelopment time. Because the Saddle Mountains unit underlies a large part of the regional discharge area along the lower Columbia and Yakima Rivers, ground water from the underlying basalt units generally has to move through the Saddle Mountains unit to discharge.

The movement of water in the Saddle Mountains unit is controlled principally by the topography and geologic structures and secondarily by the dip of the unit and by the extent and head distribution of the overburden aquifer, which overlies about 40 percent of the unit. For example, following a line down from an altitude of about $3,000 \mathrm{ft}$ near the crest of Horse Heaven Hills within the Satus Creek basin and ending in the Yakima River valley at the Yakima River (land-surface altitude of about $700 \mathrm{ft}$ ), the major control on the movement of water in the unit is topography. This topographic control is typical of the structural ridges and valleys at the Yakima Fold Belt, whereas, starting near the eastern limits of the Saddle Mountains unit and moving westward to the Columbia River (the land and basalt surface are relatively flat-lying in this area), the hydraulic gradient in the Saddle Mountains unit is small and is controlled by the low relief of this regional, gently dipping area. Some of the discharge is through the overburden aquifer in this area, but the total water movement is small compared with that in the higher relief area because of the aquifer's location in the arid central part of the plateau.

The Wanapum unit underlies $20,540 \mathrm{mi}^{2}$ (63 percent) of the $32,700 \mathrm{mi}^{2}$ within the ground-water model boundary and includes about $1,700 \mathrm{mi}^{3}$ of saturated rock material. In about 72 percent of its extent, the unit crops out (plate $4 \mathrm{a}$ ) and is available to receive recharge. Figure 8 indicates that of the $2,185 \mathrm{ft}^{3} / \mathrm{s}$ of recharge, only about $531 \mathrm{ft}^{3} / \mathrm{s}$ eventually discharges to the major rivers.

The lava flows in the Wanapum unit appear to be fairly coherent laterally within selected regions on the plateau. The modeling analysis showed that the lateral hydraulic conductivity of the unit is tight in both the relief areas of the Yakima Fold Belt and structurally complex areas, and is loose over most of the remainder of its extent. The unit has a relatively tight vertical conductance within the western part of the Palouse subprovince and within the folded areas in the Yakima Fold Belt. Over most of the remainder of the study area, it appears to be connected to the overlying overburden aquifer and Saddle Mountains unit with larger vertical conductances and has a connection to the upper Grande Ronde in which conductance varies considerably. 
In the northeastern part of the Palouse subprovince, most flow paths are short to intermediate length, with about 50 percent of the recharge discharging locally to surface-water features and topographic lows. Over most of the remainder of the Palouse subprovince, the flow paths are longer, terminating at the Columbia and Snake Rivers.

Flow paths are relatively short and terminate at surface-water features in the Blue Mountains subprovince. In the Yakima Fold Belt, flow paths originate in topographic highs, generally anticlines where hydraulic head gradients are large (100-200 ft/mi), and terminate along major rivers in the intervening synclinal valleys where hydraulic gradients are small (10-20 ft/mi). Over much of the plateau, hydraulic head gradients larger than about 80 to $100 \mathrm{ft} / \mathrm{mi}$ appear to be associated with topographic or structural control. In the area west of the John Day River, the unit is cut through by the John Day, Deschutes, and Columbia Rivers. These shallow to deep erosional cuts control the movement of water, yielding generally short flow paths. Though this area is structurally different from the Yakima Fold Belt, it appears that tectonic activity has affected it hydrologically, resulting in disruption and offsetting of the interflow zones, thus reducing the effective lateral hydraulic conductivity.

Topography, geologic structure, and surface-water features control the movement of water within the Wanapum unit. These controls on the movement of water in the Wanapum unit vary areally. For example, within the structural, semiclosed Quincy basin (fig. 1), the influence of topographic and structural controls is exhibited by the structural features of the Frenchman Hills and Beezley Hills, generally represented as topographic highs, restricting the movement of ground water in the Wanapum unit. Whereas, if water levels are observed in the Wanapum unit along a line that starts at its north-central model boundary at an altitude of about 2,400 $\mathrm{ft}$ in Lincoln County, Wash., crosses the central plateau in a south-southwesterly direction, and ends at the Snake River (altitude of about $600 \mathrm{ft}$ ), then the control that stream drainages have on the movement of water in the north and the lack of topographic control toward the Snake River would be observed. At the terminus of this line, the dip of the basalt surface and the altitude of the Wanapum unit outcrop surface in the Snake River Canyon control its lateral head gradient and, thus, the movement of water.

Of the model area, about $32,500 \mathrm{mi}^{2}$ is underlain by the upper Grande Ronde, of which about $12,025 \mathrm{mi}^{2}$ crops out. The upper Grande Ronde has a volume of about $10,550 \mathrm{mi}^{3}$. Within the outcrop area, it receives $4,131 \mathrm{ft}^{3} / \mathrm{s}$ of recharge. Much of this recharge, $2,970 \mathrm{ft}^{3} / \mathrm{s}$, discharges locally and along intermediate-length flow paths. Topography, geologic structure, and surface-water features control the movement of ground water in the upper Grande Ronde's outcrop areas. Where the Grande Ronde is overlain by the younger study units, the major streams in the study area control the movement of ground water. This is because they provide an outlet for the water in both this unit and overlying units. Because the major streams (regional drains) are at lower altitudes, there are upward vertical gradients between the upper Grande Ronde and overlying units. Further, over much of the area where the upper Grande Ronde is buried, the hydraulic gradient is relatively small and uniform and is not controlled by structural features as much as in the younger units.

About $1,950 \mathrm{ft}^{3} / \mathrm{s}$ of water is moving in the upper Grande Ronde, some of which is moving directly to other layers (fig. 8). The hydraulic connection to other layers tends to control the configuration of their head surfaces. The connection is highly variable and appears to be grossly related to thickness, distribution of structural features, overall physical setting, and major stream drainages. The conductivities of the upper Grande Ronde appear to be surprisingly loose, similar to conductivities of the Wanapum unit in most localities. However, like the Wanapum unit, it is tighter in the Yakima Fold Belt and structurally complex areas, such as the more uplifted part of the Blue Mountains subprovince. This similarity in the distribution of hydraulic conductivity for the Wanapum unit and upper Grande Ronde probably is related to the relatively rapid extrusion and emplacement of these units and to the timing of the onset of the tectonic/structural activity in the Columbia Plateau. Thus, both units probably were exposed to the same geologic processes in most locations. The distribution of thickness and continuity of geologic structures across Wanapum unit pinchouts into the upper Grande Ronde supports this concept.

Controls on ground-water movement in the upper Grande Ronde are highly variable and differ from those in the Wanapum unit. For example, following a line from the northern end of the Quincy basin on the Beezley Hills, which creates the basin's northern boundary, southward to the Columbia River across both the Frenchman Hills and the Saddle Mountains anticlines, the movement of water in the upper Grande Ronde is controlled predominantly by the location of the Columbia River and its hydraulic characteristics, and not by the gradient and dip of the basalt 
surface. Conversely, the movement of water in the overlying Wanapum unit in this area is controlled by topography and structural features. Similarly, following a line that starts in the northeastern part of the modeled area and goes south-southeast to the Columbia River, the water movement is relatively unaffected by surface-water features and tends to follow the structural gradient of the basalt surface. As a last example, controls vary considerably along a line from the crest of the Blue Mountains (an outcrop area typified by rugged topography) westward downslope (through the Walla Walla River basin) to the Columbia River. Topography and structure control movement in the uplifted outcrop area, where numerous small stream drainages discharge water in local flow systems (plate 8d): Where the upper Grande Ronde is buried under the Wanapum unit, its potentiometric surface becomes flatter and control is shifted from topography and stream drainages to depth of burial by younger units, gradient of the basalt surfaces, and location and altitude of the regional drains.

The lower Grande Ronde covers about 62 percent of the modeled area $\left(20,110 \mathrm{mi}^{2}\right)$ and includes about $13,400 \mathrm{mi}^{3}$ of basalt or 52 percent of the aquifer system's volume. The calculated budget for this layer is presented in figure 9 and table 8 and is a first approximation to its actual water budget. This model layer (5) was chosen to represent the deeper flow system, and there is little or no information on its distribution of thickness, hydraulic properties, hydraulic head, and water chemistry. The unit receives and gives water only to the upper Grande Ronde, and the hydraulic connection between these layers was based solely on two factors: (1) reasonableness of the lateral to vertical ratio of hydraulic conductivity (combined with best regional head match in the other units during model calibration), and (2) reasonableness of calculated vertical head gradients between the two Grande Ronde layers. Thus, model representation of the deep flow system, as simulated by layer 5, cannot be considered calibrated, but only checked that it is reasonable.

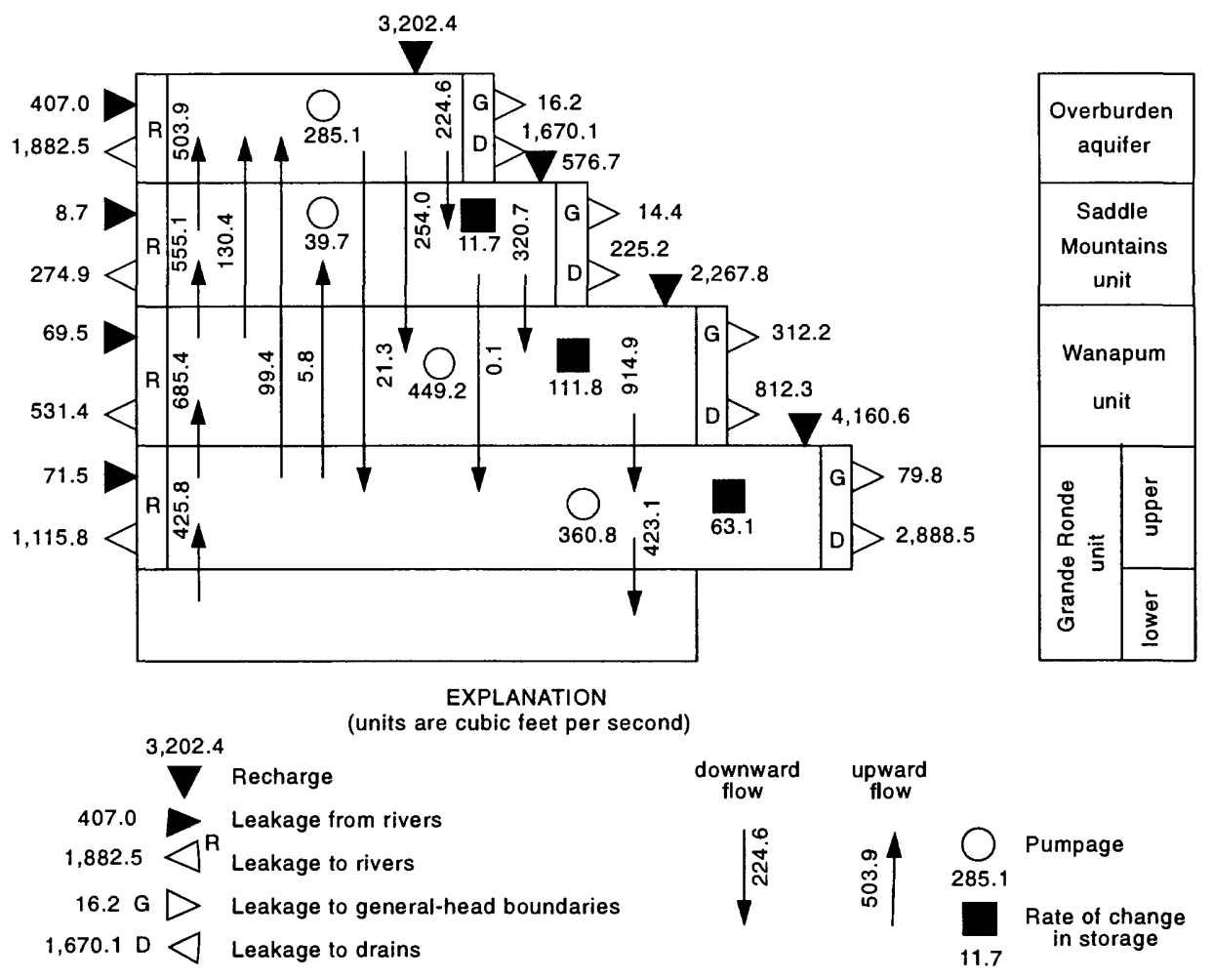

Figure 9.-- Schematic diagram showing the model-calculated 1983-85 time-averaged water budget. 
Several layers probably should have been used to represent the lower Grande Ronde, because too much water was trying to move through this unit under the present model configuration. In reality, the flow should become progressively less as one moves down in a vertical section, with slow movement and flux near the bottom of this layer. Using a single layer in the model construction does not allow for this flow variation. Still, with the acceptable ranges of parameters used, the simulated flow system in this layer appears to be reasonable. Water enters the lower Grande Ronde in a band around its peripheral boundary and, throughout the remainder of its lateral extent, ground-water flow is upward to the upper Grande Ronde. This type of flow system should propagate downward, resulting in a more confined and less active flow system with depth.

The predevelopment model-calculated areal distribution of the quantity of water entering or leaving through the bottom of the upper four model layers (plate 10) is a function of the vertical head gradient between layers and the vertical conductance of the rock materials of the layers (see plate 7). The total quantities of water moving through the upper and lower surfaces of each layer (excluding recharge), from youngest (1) to oldest (5), are $660 \mathrm{ft}^{3} / \mathrm{s}, 987 \mathrm{ft}^{3} / \mathrm{s}, 2,189 \mathrm{ft}^{3} / \mathrm{s}, 2,375 \mathrm{ft}^{3} / \mathrm{s}$, and $844 \mathrm{ft}^{3} / \mathrm{s}$; layers listed in order of activity are thus $4,3,2,5$, and 1 . These quantities correspond well with the conceptual model of ground-water movement, especially when considered in conjunction with the volume of saturated rock material and areal extent of each layer.

About $80 \mathrm{ft}^{3} / \mathrm{s}$ moves downward through the bottom of the overburden unit: $26 \mathrm{ft}^{3} / \mathrm{s}$ to the Saddle Mountains unit, $49 \mathrm{ft}^{3} / \mathrm{s}$ to the Wanapum unit, and $7 \mathrm{ft}^{3} / \mathrm{s}$ to the upper Grande Ronde, and $578 \mathrm{ft}^{3} / \mathrm{s}$ moves upward from the underlying basalt units: $369 \mathrm{ft}^{3} / \mathrm{s}$ from the Saddle Mountains unit, $117 \mathrm{ft}^{3} / \mathrm{s}$ from the Wanapum unit, and $92 \mathrm{ft}^{3} / \mathrm{s}$ from the upper Grande Ronde. The difference between the gain and loss (about $500 \mathrm{ft}^{3} / \mathrm{s}$ ) represents ground water that has moved from the basalt units into the overburden aquifer and then is discharged. The distribution of ground-water flow through the bottom of the overburden aquifer (plate 10a) shows where discharge from the aquifer system moves through the overburden aquifer.

The Saddle Mountains unit loses about $88 \mathrm{ft}^{3} / \mathrm{s}$ through its bottom surface and gains about $503 \mathrm{ft}^{3} / \mathrm{s}$ from the Wanapum unit. The difference between gains and losses, $414 \mathrm{ft}^{3} / \mathrm{s}$, is mainly water moving from the Wanapum unit, which then discharges through the Saddle Mountains unit.

About $724 \mathrm{ft}^{3} / \mathrm{s}$ moves through the bottom of the Wanapum unit into the upper Grande Ronde and about $708 \mathrm{ft}^{3} / \mathrm{s}$ moves from the upper Grande Ronde into the Wanapum unit; the difference, $16 \mathrm{ft}^{3} / \mathrm{s}$, represents a net loss from the Wanapum unit to the upper Grande Ronde. This water discharges from the upper Grande Ronde to streams, lakes, and seeps and springs. The upper Grande Ronde loses about $421 \mathrm{ft}^{3} / \mathrm{s}$ to the lower Grande Ronde, all of which moves back into the upper Grande Ronde.

The model-calculated vertical head differences between a layer and the underlying layer to which it is connected are shown on plate 11. These differences drive the fluxes of water presented above. For the overburden aquifer, the mean difference is $10 \mathrm{ft}$ and ranges from -40 to $210 \mathrm{ft}$. The largest differences are in the Toppenish Creek and Naches Creek valleys. Large differences are caused by smaller hydraulic conductivities and, in some areas, by lower controlling altitude for regional discharge from the basalts than the bottom of the overburden aquifer (rivers have cut through the overburden aquifer to the basalts). The smallest differences, where the heads of the layers are collapsed, occur at or near points of discharge and where the overburden aquifer consists of coarse-grained materials. The mean difference for the Saddle Mountains unit is about $65 \mathrm{ft}$ and ranges from -75 to $335 \mathrm{ft}$; the largest differences are in the Rattlesnake Hills and in the upper reaches of Willow Creek Valley, Oreg. The mean difference for the Wanapum unit is $100 \mathrm{ft}$ and ranges from -135 to $400 \mathrm{ft}$. Large thickness and large head gradients within the Wanapum unit and upper Grande Ronde account for the larger differences. The mean difference for the upper Grande Ronde is about $75 \mathrm{ft}$; differences range from -240 to about 1,050 ft. They are largest near the northwestern and northern margins of the Blue Mountains. 


\section{3-1985 Time-Averaged Conditions}

The regional aquifer was analyzed for its response to current conditions by using a time-averaged approach to a steady-state simulation for the period spring 1983 through spring 1985. Three of the major water-management influences (ground-water pumping, dammed rivers, and irrigated and dry-land agriculture) on the ground-water system during this simulation interval are included in this analysis.

About 85 percent of the pumpage, discussed in the section "Pumpage", is applied to irrigate crops; almost all the withdrawal is from three of the five model layers (about 25, 40, and 32 percent is pumped from the overburden aquifer, Wanapum unit, and upper Grande Ronde, respectively). Most of the wells drilled into the basalt are uncased below the top of the basalt. Each open borehole forms a conduit for vertical flow within and between units, so the rate of vertical flow has increased since development began; this was discussed in the subsection "Vertical Hydraulic Conductance Per Unit Area".

Many of the rivers flowing across the project area, especially the Columbia, Snake, and Yakima Rivers, have been dammed; as a result, the river stage has been raised along most reaches. River stages, at places, have risen above the bottom of the units that had been exposed on the valley walls before the dams were built. Higher-thannatural pool elevations raised the head in the hydrologic unit to which they are connected and provide a constanthead control for the flux of water between the aquifer system and the rivers. The pools effectively add a stable control for ground-water movement near the major rivers.

Irrigation is by distribution of surface water withdrawn from the dammed rivers and by ground water pumped from wells beneath the irrigated areas. The surface water is applied at a rate of about $4 \mathrm{ft} / \mathrm{yr}$; ground water is applied at a lower rate--about $1.5 \mathrm{ft} / \mathrm{yr}$.

Water levels throughout the area irrigated by ground water have declined. Beneath areas where surface water has been imported, however, water levels have risen, in many places nearly to ground level. Farm drains have been built in these locations; they have been discussed in the section "Farm Drains". The water added to the aquifers by infiltration of surface-water irrigation has expanded the zone of saturation in the upper two units. The overburden aquifer's area of saturation is about 55 percent larger, and the Saddle Mountains unit is about 17 percent larger, than under predevelopment conditions.

Recharge estimates for current conditions have been discussed in the section "Recharge"; it results from deep percolation of precipitation within the project area and infiltration of water applied for irrigation. The rate of recharge is about $10,208 \mathrm{ft}^{3} / \mathrm{s}(4.24 \mathrm{in} / \mathrm{yr})$, about $3,640 \mathrm{ft}^{3} / \mathrm{s}$ more than the predevelopment period. The recharge to the four units that crop out (overburden aquifer, Saddle Mountains unit, Wanapum unit, and upper Grande Ronde) is $3,202,577,2,268$, and $4,161 \mathrm{ft}^{3} / \mathrm{s}$, about $31,6,22$, and 41 percent of the total recharge, respectively.

The model-calculated water budget for the time-averaged simulation is presented in table 7 for the regional aquifer system, in table 8 for each layer (including flow between layers), and in a schematic diagram in figure 9. The calculated distribution of ground-water discharge from the regional aquifer system is shown on plate $8 \mathrm{e}$, and plate 12 shows the model-calculated water-level contours for each layer.

\section{Flow System}

About 55 percent of the recharge discharges to drains and about 37 percent discharges to rivers (table 7). The percentage of discharge to drains is slightly less than under predevelopment conditions and the percentage to rivers is now slightly more. Pumpage is about $1,135 \mathrm{ft}^{3} / \mathrm{s}$ or only about 11 percent of the recharge (table 7). However, because pumpage is concentrated within areas, it locally exceeds the sum of recharge and ground-water inflow and water levels have declined. Where water levels have declined, a part of the water released from storage for the time-averaging period was input to the model as recharge wells. This change in storage is about $186 \mathrm{ft}^{3} / \mathrm{s}$. For the Saddle Mountains unit, Wanapum unit, and upper Grande Ronde, the ratios of the change in storage to pumpage 
were 29,25 , and 17 percent, respectively. The leakage from rivers and the change in storage are about 7 percent of the recharge. Though these two quantities are relatively small, they are important locally as sources of water. The change in storage is about 16 percent of the ground-water pumpage (that is, it supplied about 16 percent of the pumpage). Along parts of Crab Creek and in the Odessa-Lind pumpage center, these two water-budget components provide water for ground-water irrigation. Similarly, the leakage from some of the streams locally provides water for ground-water pumpage. Discharge through seepage faces (GHBs) is only 4 percent of the recharge. The value is about the same as under predevelopment conditions because the GHBs are not located near areas with long-term changes in water levels.

The overburden aquifer receives about $3,202 \mathrm{ft}^{3} / \mathrm{s}$ of recharge (about a 27 -fold increase from predevelopment conditions, table 8 ), most of which discharges locally to drains and rivers (mainly the Yakima and Columbia Rivers). The discharge to drains and rivers amounts to about 111 percent of the overburden aquifer recharge. Leakage from rivers and the underlying basalts supplies an additional $1,141 \mathrm{ft}^{3} / \mathrm{s}$ of water to the overburden aquifer. However, considering the leakage of water to underlying basalts, only about 7 percent of the overburden discharge is flow received from underlying basalt units. About 7 percent of the overburden aquifer discharge is ground-water pumpage.

About 42 percent of the Saddle Mountains unit recharge $\left(577 \mathrm{ft}^{3} / \mathrm{s}\right)$ discharges locally. Leakage to other layers exceeds the leakage to the Saddle Mountains unit by about $39 \mathrm{ft}^{3} / \mathrm{s}$. Pumpage from the Saddle Mountains unit amounts to only about 7 percent of its recharge. However, pumpage is locally important, as can be seen by the change in storage, which is about 29 percent of the pumpage.

The Wanapum unit receives about $2,268 \mathrm{ft}^{3} / \mathrm{s}$ of recharge (about $83 \mathrm{ft}^{3} / \mathrm{s}$ more than under predevelopment conditions), of which about $1,125 \mathrm{ft}^{3} / \mathrm{s}$ is local discharge, about 93 percent of that under predevelopment conditions. Pumpage is about 12 percent of the Wanapum unit's discharge, and discharge to other layers amounts to about 43 percent of the unit's total discharge. Additional discharge from this unit is compensated for by water received from the overlying overburden aquifer and Saddle Mountains unit. The change in storage is about 25 percent of the Wanapum unit's pumpage. Leakage to GHBs from the Wanapum unit, though only about 14 percent of recharge, is nearly 70 percent of the pumpage and is an important budget item. Thus, the erosional and tectonic activity, exposing sections of the Wanapum unit, has resulted in a major geologic control on water movement.

The upper Grande Ronde discharges about $2,970 \mathrm{ft}^{3} / \mathrm{s}$ locally, a quantity similar to the discharge under predevelopment conditions. This local discharge is about 70 percent of the unit's recharge. The ground-water pumpage for the upper Grande Ronde unit is only about 6 percent of its discharge and 9 percent of its recharge. The change-in-storage term is only about 17 percent of the pumpage and 2 percent of the recharge because of smaller water-level declines. In turn, smaller declines are due to the larger storage capacity and greater lateral ground-water inflow in areas of pumpage. Because most water-budget components are similar for both simulations for this layer, pumpage primarily is compensated for by the increased leakage from the Wanapum unit (about $190 \mathrm{ft}^{3} / \mathrm{s}$ ) and secondarily by the change in storage (about $63 \mathrm{ft}^{3} / \mathrm{s}$ ), increase in recharge (about $83 \mathrm{ft}^{3} / \mathrm{s}$ ), and increase in leakage from rivers (about $25 \mathrm{ft}^{3} / \mathrm{s}$ ). The water budget and flow system for the lower Grande Ronde are similar to those under predevelopment conditions. Differences relate mainly to localized changes in lateral and vertical head gradients.

The overburden aquifer and the Saddle Mountains unit are hydrologically important components of the aquifer system. This is shown by the information presented in tables 7 and 8 and in figure 9 . The overburden aquifer was hydrologically important under predevelopment conditions, although it encompassed only 9 percent of the modeled area and consisted of only 0.5 percent of the volume of the saturated aquifer system. For the time-averaged simulation, the overburden aquifer increased in area by about $1,600 \mathrm{mi}^{2}$ and in volume by about $32 \mathrm{mi}^{3}$. Although it still makes up only about 14 percent of the total aquifer area and 0.6 percent of the total aquifer volume, it now receives more than 30 percent of the recharge to the aquifer system, and about 38 percent of the discharge from the aquifer system is through the overburden aquifer. 
The increase in area and volume of the saturated rock materials, the increase in recharge, and the large increase in water received from the overburden aquifer show the increased hydrologic importance or activity of the Saddle Mountains unit. Local discharge is about $240 \mathrm{ft}^{3} / \mathrm{s}$ (about 42 percent of its recharge) compared with about $31 \mathrm{ft}^{3} / \mathrm{s}$ under predevelopment conditions. The total quantity of water moving through its top and bottom surfaces has increased by about $624 \mathrm{ft}^{3} / \mathrm{s}$. The increased importance of the Saddle Mountains unit as a transmitter of water results from surface-water irrigation. Similarly, as a result of surface-water irrigation, the Wanapum unit now receives about $575 \mathrm{ft}^{3} / \mathrm{s}$ of water from these two overlying units, compared with about $137 \mathrm{ft}^{3} / \mathrm{s}$ for predevelopment conditions.

The derived regional estimates of lateral hydraulic conductivity (table 1 and plate 5) represent the effective conductivity for large sections of the aquifer materials. The distribution of $\mathrm{K}_{\mathrm{h}}$ values provides major control on the movement and availability of water in the regional aquifer system. Though the materials are not 'tight' in comparison with other media (Neuzil, 1986), the effective conductivity is relatively low and limits lateral flow within the aquifer system. For example, under a large but acceptable range of hydraulic conductivities, movement of water from areas of large recharge to areas of small recharge was limited greatly. Tests on the effects of increasing recharge to increase lateral head gradients, and thus flux, resulted mainly in higher calculated water levels in areas of large recharge and more discharge to nearby drains. Even with larger calculated lateral head gradients, the additional volume of water from the increased recharge could not be moved along distances of 20 to $40 \mathrm{mi}$.

The above indicates that ground-water pumpage needs to be met locally by aquifer storage and direct recharge. For example, a slice through the model was defined upgradient of the Odessa-Lind pumping center. Calculated flow across this slice represents most of the lateral ground-water inflow to this area of downward vertical gradients. Calculated flow was about $73 \mathrm{ft}^{3} / \mathrm{s}$ moving laterally into this area: about $40 \mathrm{ft}^{3} / \mathrm{s}$ in the lower Grande Ronde, only about $3 \mathrm{ft}^{3} / \mathrm{s}$ in the Wanapum unit, and about $30 \mathrm{ft}^{3} / \mathrm{s}$ in the upper Grande Ronde. Because this area receives small amounts of precipitation (generally less than $11 \mathrm{in} / \mathrm{yr}$ ), and even smaller amounts of recharge (generally less than $2 \mathrm{in} / \mathrm{yr}$ ), ground-water pumpage in excess of the lateral rates must be met by other sources of water. As discussed earlier, the pumpage is met by leakage from Crab Creek and the change in storage. The change in storage shows that, because the pumpage cannot be met by recharge (including captured recharge) and lateral inflow, there are water-level declines. The small lateral inflow and recharge and relatively large amount of ground-water pumpage (plate 4c) for the Wanapum unit results in the observed large change in storage (Cline, 1984; Lane and Whiteman, 1989).

Water-level declines in the Wanapum unit in this area are increased further as a result of the numerous composite, uncased wells in this area of downward vertical gradients. Flow in the uncased wells increases leakage from the Wanapum unit to the upper Grande Ronde. As a result of the declines, there has been a slow but steady shift, since about 1968, in the pumpage distribution from the Wanapum unit to the upper Grande Ronde; many irrigation wells now pump from the upper Grande Ronde rather than the Wanapum unit. However, the declines in the Wanapum unit affect the underlying upper Grande Ronde because the initial well yields for the uncased and cased wells penetrating both units were dependent on the flow contribution from the Wanapum unit in the uncased wells.

Using $\mathrm{K}_{\mathrm{h}}$, calculated gradients, and estimates of porosity, ground-water velocity was estimated for each layer. The estimated median velocities for layers 1 to 5 are $1.9,0.2,0.4,0.2$, and $0.1 \mathrm{ft} / \mathrm{d}$, respectively. The velocity of the overburden aquifer ranges from 0.005 to $85 \mathrm{ft} / \mathrm{d}$, that of the Saddle Mountains unit ranges from $0.006 \mathrm{fo} 2.3 \mathrm{ft} / \mathrm{d}$, that of the Wanapum unit ranges from 0.003 to $4.5 \mathrm{ft} / \mathrm{d}$, that of the upper Grande Ronde ranges from 0.001 to $6.4 \mathrm{ft} / \mathrm{d}$, and that of the lower Grande Ronde ranges from 0.0008 to $2.6 \mathrm{ft} / \mathrm{d}$. The velocity in the lower Grande Ronde is, in general, much slower than those of the other units because of smaller $\mathrm{K}_{\mathrm{h}}$ and larger saturated thickness. Slow velocity corresponds to the deeper flow system. On the basis of the ranges in velocity, transit times through the aquifer system would range from 10 to 30,000 years. The former represents local to intermediate flow systems and the latter represents flow in the deeper system. The velocities, although approximate and highly variable, represent vertically and laterally averaged regional estimates that incorporate the limiting conductivities, flow barriers, variations in thickness, and heterogeneity present in the aquifer system. 
The time-averaged, model-calculated distribution of the quantity of water entering or leaving the bottom of the upper four model layers (plate 13) is a function of the vertical head difference (plate 14) and the model-derived vertical conductance (plate 7). The total quantity of water that moves between layers is about $4,565 \mathrm{ft}^{3} / \mathrm{s}$ or about 45 percent of the time-averaged recharge. The remaining 55 percent discharges along short flow paths. The total quantities of water moving through the upper and lower (top and bottom) surfaces of each layer (excluding recharge), from youngest (1) to oldest (5), are about $1,234 \mathrm{ft}^{3} / \mathrm{s}, 1,610 \mathrm{ft}^{3} / \mathrm{s}, 2,860 \mathrm{ft}^{3} / \mathrm{s}, 2,576 \mathrm{ft}^{3} / \mathrm{s}$, and $849 \mathrm{ft}^{3} / \mathrm{s}$, respectively. Layers listed in order of hydrological activity are 3, 4, 2, 1, and 5. More water flows in the upper three layers than under predevelopment conditions. For example, the overburden aquifer and the Saddle Mountains unit have about $574 \mathrm{ft}^{3} / \mathrm{s}$ and $623 \mathrm{ft}^{3} / \mathrm{s}$ more water moving between them and other layers than during the predevelopment period (table 8). Additionally, more water now moves between the Wanapum unit surfaces than between the upper Grande Ronde surfaces. These changes result primarily from the increase in recharge due to surface-water irrigation and secondarily from ground-water pumpage.

The overburden aquifer receives about $734 \mathrm{ft}^{3} / \mathrm{s}$ from underlying units and loses about $500 \mathrm{ft}^{3} / \mathrm{s}$ to underlying units, or a net gain of about $234 \mathrm{ft}^{3} / \mathrm{s}$. This water discharges locally and to the major streams. Upward flow to the overburden aquifer typically occurs at or near the regional discharge area.

About $1,610 \mathrm{ft}^{3} / \mathrm{s}$ moves between the Saddle Mountains unit and other units; this quantity is about 280 percent of its recharge. The unit gains about $225 \mathrm{ft}^{3} / \mathrm{s}$ from the overburden aquifer, $555 \mathrm{ft}^{3} / \mathrm{s}$ from the Wanapum unit, and about $6 \mathrm{ft}^{3} / \mathrm{s}$ from the upper Grande Ronde. This quantity is about 135 percent of its recharge. The unit loses about $504 \mathrm{ft}^{3} / \mathrm{s}$ to the overburden aquifer and about $321 \mathrm{ft}^{3} / \mathrm{s}$ to the Wanapum unit. This quantity is about 143 percent of its recharge. Thus, the Saddle Mountains unit has a loss to the overburden aquifer of about $279 \mathrm{ft}^{3} / \mathrm{s}$ and a gain of about $234 \mathrm{ft}^{3} / \mathrm{s}$ from the Wanapum unit, resulting in a net loss of about $39 \mathrm{ft}^{3} / \mathrm{s}$. Under predevelopment conditions, the unit had a net gain of about $71 \mathrm{ft}^{3} / \mathrm{s}$ from the other layers. The difference between the two simulations is due to the effects of surface-water irrigation, which has caused head increases and downward vertical gradients over a larger area. This has resulted in larger fluxes of water into and out of the unit (table 8).

The Wanapum unit has about $2,860 \mathrm{ft}^{3} / \mathrm{s}$ ( 126 percent of its recharge) moving between it and other units. Of this quantity, about $1,260 \mathrm{ft}^{3} / \mathrm{s}$ is water gained from other units and about $1,601 \mathrm{ft}^{3} / \mathrm{s}$ is water lost to other units. The Wanapum unit gains about $575 \mathrm{ft}^{3} / \mathrm{s}$ from overlying units and about $685 \mathrm{ft}^{3} / \mathrm{s}$ from the upper Grande Ronde. Leakage from the Wanapum unit to overlying units is about $685 \mathrm{ft}^{3} / \mathrm{s}$, and leakage to the upper Grande Ronde is about $915 \mathrm{ft}^{3} / \mathrm{s}$. Thus, the upper Grande Ronde has a net gain of about $230 \mathrm{ft}^{3} / \mathrm{s}$ from the Wanapum unit, and the overburden aquifer and Saddle Mountains unit together have a net gain of $111 \mathrm{ft}^{3} / \mathrm{s}$ from the Wanapum unit, mainly at or near the regional discharge area. The latter value is $373 \mathrm{ft}^{3} / \mathrm{s}$ less than under predevelopment conditions, whereas, the former value is about $214 \mathrm{ft}^{3} / \mathrm{s}$ more than under predevelopment conditions.

The upper Grande Ronde has about $2,576 \mathrm{ft}^{3} / \mathrm{s}$ (about 62 percent of its recharge) moving to and from it. This is about $200 \mathrm{ft}^{3} / \mathrm{s}$ more than predevelopment conditions and represents the increase in leakage from the Wanapum unit. The upper Grande Ronde has a net gain in ground water of about $149 \mathrm{ft}^{3} / \mathrm{s}$; under predevelopment conditions, this unit had a net loss of about $68 \mathrm{ft}^{3} / \mathrm{s}$. The water budget for the lower Grande Ronde is the same as for predevelopment conditions. That is, about $423 \mathrm{ft}^{3} / \mathrm{s}$ is leakage from the upper Grande Ronde and the same quantity discharges back to the upper Grande Ronde.

The calculated vertical head differences between units (plate 14) are probably the best regional estimates to date for the aquifer system. Because these head differences implicitly include the vertical head variations within a unit as a result of the vertical averaging, however, these regional-scale estimates do not address vertical differences at any one location. For example, the difference between layers 3 and 4, in the central part of the Palouse subprovince west of Cow Creek (plate 14c), is between 100 and $200 \mathrm{ft}$. In this downward vertical gradient area, the head differences within layers 3 and 4 are on the order of $200 \mathrm{ft}$, so that the net head difference that can be encountered in drilling a thousand-foot well is probably on the order of $400 \mathrm{ft}$. 
The upward vertical gradients in the upper three layers for the time-averaged simulation are rather narrow zones located at or near stream courses (plate 14), similar to predevelopment conditions. For example, more than 80 percent of the Wanapum unit's flow system has downward vertical gradients to the upper Grande Ronde. The time-averaged model-calculated distribution of vertical gradients resulted in a net flux of about $229 \mathrm{ft}^{3} / \mathrm{s}$ to the upper Grande Ronde, whereas a similar distribution of upward and downward flow areas for predevelopment conditions gave only about a $15 \mathrm{ft}^{3} / \mathrm{s}$ net flux to the upper Grande Ronde.

\section{Discharge to Basins and Streams}

Discharge from the aquifer system (plate 8e) shows the areal distribution of ground-water discharge, but does not address discharge within specific drainage basins or along selected stream reaches. Therefore, the ground-water discharge within 27 basins is shown in table 9, together with other relevant information, and the discharge to 16 selected stream reaches is shown in table 10. The following discussions will describe the water budget, with emphasis on the ground-water discharge of those basins and to those stream reaches (see plate $8 \mathrm{f}$ for location). Twenty-four of the basins are a subset of the 53 basins (plate $4 \mathrm{~b}$ ) for which ground-water recharge was estimated using the deep percolation model.

In addition to providing information about a specific basin, the estimates of ground-water discharge within a basin provided a calibration standard. That is, one of the criteria used during model calibration was that the total calculated discharge within a basin should be equal to or greater than the estimated average-annual baseflow and less than the estimated average-annual streamflow. Because of the size of the ground-water model cells, the regional scale of the model, and the inherent error in the estimates of recharge and baseflow (and in some cases, annual streamflow), the calibration criteria were not an exact standard, but measured the reasonableness of the calculated discharges and model reliability. This meant no local adjustments were made in recharge and hydraulic characteristics during the calibration process in order to obtain a better match between discharge quantities; rather, the regional distribution of recharge and hydraulic characteristics was assumed to be reasonable when the calculated discharges approached the criteria. These criteria generally were met when the observed and calculated water-level surfaces matched reasonably. In some cases, the calculated discharge was less than the estimated baseflow, and in other cases, it was greater than the estimated annual streamflow. For example, the calculated discharge for Glade Creek basin exceeded the annual streamflow; however, the calculated discharges for Pine Creek and Rock Creek basins, Wash., (which are next to Glade Creek) were less than the estimated baseflow. Thus, the regional flow system simulated by the model was assumed to be reasonable in this area, and better matches could be achieved only by localized adjustments of either recharge or the hydraulic characteristics.

There are some general relations between discharge and precipitation--terrain, recharge, and drainage area (table 9). The basins in areas dominated by local flow systems have the most ground-water discharge and the most recharge (and usually, the most precipitation). These basins are generally at high altitudes in steep terrain, and much of the recharge travels in short flow paths to surface-drainage features. This flow system corresponds to the conceptual model of topography controlling ground-water movement in steep terrain areas. Examples are the Umatilla River and Satus Creek basins.

Basins with smaller values of discharge generally correspond to either small recharge or small drainage area. In the latter case, a small drainage area (for example, South Fork Palouse River, table 9) simply controls the total amount of water available in a basin; lateral ground-water underflow, however, can supply additional water. In the former case, net basin water supply is limited by the amount of recharge, as shown by the ratio of recharge to discharge (table 9). The basins with a large ratio of recharge to discharge (greater than about 1.8) have deep water levels, are located in areas of generally flat topography, and have small amounts of discharge (for example, Bowers Coulee). Much of the ground-water recharge in these basins is incorporated in the regional flow system. 


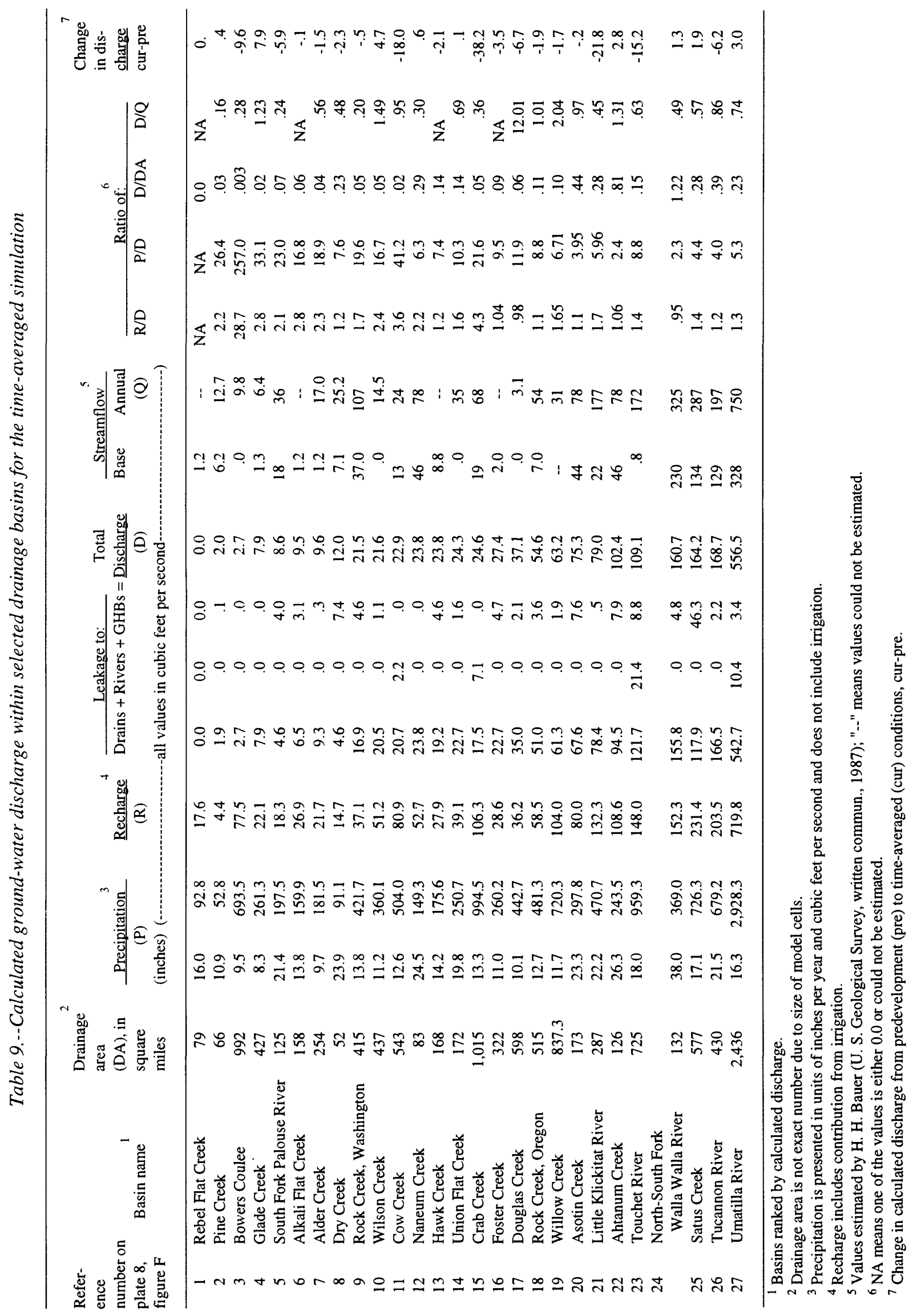


Table 10.--Model-calculated ground-water discharge to selected river reaches

[Values in cubic feet per second]

\begin{tabular}{llrc}
\hline $\begin{array}{l}\text { Reference } \\
\text { letter on } \\
\text { plate 8, } \\
\text { figure F }\end{array}$ & \multicolumn{1}{c}{ Stream reach } & 1983-85 \\
& & Predevelopment & time-averaged \\
\hline A & Upper Columbia River & 291.1 & 831.4 \\
B & Snake River & 491.7 & 435.5 \\
C & Lower Yakima River & 45.3 & 424.8 \\
D & Lower Columbia River & 383.9 & 354.1 \\
E & Upper Yakima River & 185.4 & 303.8 \\
F & Klickitat River & 217.2 & 225.7 \\
G & Palouse River & 160.4 & 164.3 \\
H & Lower Crab Creek & 76.3 & 145.1 \\
I & Walla Walla River & 72.1 & 115.3 \\
J & Naches River & 54.7 & 97.5 \\
K & Rocky Ford-Crab Creek & 10.8 & 90.9 \\
L & Grande Ronde River & 74.0 & 74.0 \\
M & Spokane River & 52.4 & 51.5 \\
N & Deschutes River & 47.4 & 50.6 \\
O & John Day River & 42.5 & 45.9 \\
P & Moses Coulee & 11.5 & 9.8 \\
& & & \\
\hline & TOTAL & $2,216.7$ & $3,420.2$ \\
\hline
\end{tabular}

Ground-water development in basins with large discharge has a potential for capturing more of the discharge, thus limiting head declines. This general concept also depends on the total amount of recharge. However, except for the northeastern part of the study, the areas with the most discharge (recharge) typically are located in mountainous terrain where soils are poorly developed, and therefore are not conducive for agricultural development. In basins with less ground-water discharge, ground-water development most likely would take water from storage and water levels would decline; examples are Bowers Coulee, Pine Creek, and South Fork Palouse River basins. This last aspect is especially true for the plateau, because the small effective regional hydraulic conductivity of the basalts greatly limits lateral ground-water inflow. Between the two extremes, intermediate basins with ratios of recharge to discharge from 1.4 to 2.2 would respond in a more complicated and less predictable manner.

The ratio of the calculated discharge to the mean annual flow of the streams in the basins indicates the aquifer system's connection to the surface-water system. This ratio ranges from 0.16 to 12.0 . The small ratios generally indicate that ground-water development would affect late summer baseflows, and large ratios indicate that streamflow would be affected throughout the year. Thus, any ground-water or surface-water development will affect the flow in the system, but the magnitude, location, and timing of the effects would be highly variable. On a regional basis, perturbations to the ground-water system can probably propagate as much as an estimated $20 \mathrm{mi}$ in the aquifer system, or until a major stream/drain is encountered. Long-term development of a fairly large quantity of water would increase the distances over which these effects potentially can spread across several basins.

Calculated ground-water discharges to 16 selected streams or stream reaches are shown in table 10 and on plate 8f. Calculated discharges for 27 other stream reaches within the study area are listed in table 9; that is, table 9 presents discharge values for all model cells within a basin and table 10 presents discharge values only for those 
cells representing a stream. The total discharge to the streams (table 10) is about 3,418 $\mathrm{ft}^{3} / \mathrm{s}$ or about 33 percent of the recharge. The remainder of the discharge (recharge) is partitioned between the 27 selected basins ( 16 percent of recharge), ground-water pumpage (11 percent of recharge), and drains (40 percent of recharge).

The river cells ( 591 cells) represent the major regional drains, and the drain cells $(2,841$ cells $)$ represent local to intermediate flow systems. The drains typically are located within local flow systems in areas (generally mountainous) receiving precipitation in amounts greater than about $15 \mathrm{in} / \mathrm{yr}$. Drain cells receive more ground-water discharge than river cells (tables 7 and 8 ); the average discharge to river cells is about $6.5 \mathrm{ft}^{3} / \mathrm{s}$, however, compared to about $2 \mathrm{ft}^{3} / \mathrm{s}$ from drain cells, further showing how water is partitioned throughout the aquifer system.

Most discharge to the major streams has traveled along regional flow paths. This is ground water that moves down from higher altitude areas, intermingles with and incorporates water moving along local and intermediate flow paths, and eventually discharges at locations in lowland areas, usually synclinal valleys. About $1,000 \mathrm{ft}^{3} / \mathrm{s}$ of this discharge occurs within the regional discharge area; note that the upper Yakima River and part of the upper Columbia River are not considered within the regional discharge area. To put this quantity in perspective with respect to the flow in the major streams, $1,000 \mathrm{ft}^{3} / \mathrm{s}$ is about 27 percent, 2 percent, and 1 percent of the mean annual flow of the Yakima, Snake, and Columbia Rivers, respectively. Additionally, the calculated discharge to the lower Columbia River is less than one-third of 1 percent of the mean annual flow of the Columbia River at the Dalles, Oreg., and is less than 3 percent of the average-annual precipitation that falls within the ground-water model boundaries.

About 69 percent of the discharge to the selected streams goes to the Yakima, Snake, and Columbia Rivers (table 10). These rivers are the major regional drains of the aquifer system. The John Day and Deschutes Rivers also provide major control to the regional ground-water flow system. However, because their effective drainages within the model boundaries are not as large as the major drains and they are located in a relatively low precipitation area (small recharge), the discharge to these two rivers is small and amounts to only about 1 percent of their mean annual flow. The Umatilla River also represents a major drain for the southeastern part of the aquifer system. However, the complete basin, rather than the river itself, was investigated in this study (see table 9). Although the discharge to the Umatilla River is large, second only to that of the upper Columbia River reach, much of this discharge occurs within local flow systems at higher altitudes.

\section{Effects of Water Development Based on Model Simulations}

The effects of water development are changes in ground-water storage (water levels) and changes in the distribution and rates of ground-water recharge and discharge. These changes are caused by ground-water pumpage, application of most of the pumpage to croplands, delivery and irrigation application of surface water, changes in land use, and the construction of dams.

The rate and distribution of ground-water pumpage have been described previously. Local effects of pumpage have been discussed by Cline (1984) for the Odessa-Lind pumping center, Davies-Smith and others (1988) for the Umatilla, Oreg., area, MacNish and Barker (1976) for the Walla Walla River basin, and by Barker (1979) and Lum and others (1990) for the Pullman, Wash.-Moscow, Idaho area. Similarly, the effects of the use of surface water for irrigation have been discussed in previous sections, described for the CBIP by Tanaka and others (1974), and for parts of the Yakima River basin by Bolke and Skrivan (1981) and Prych (1983). The effects of changing land use are included implicitly in the effects of surface- and ground-water irrigation practices and, therefore, in the changes in ground-water recharge from predevelopment to current land-use conditions. The latter has been described in the "Recharge" subsection and in Bauer and Vaccaro (1990). Changes in the ground-water flow system resulting from the construction of dams were not addressed directly in this study; they are included in the regional effects.

The net regional effect of water-development practices, including the effects of land-use changes, is shown by the information presented in table 7 for the regional aquifer system and in table 8 for the model layers. The calculated change in the water-budget components for the upper four model layers is shown graphically in figure 10. The largest change in the regional water budget was an increase of about $3,640 \mathrm{ft}^{3} / \mathrm{s}$ for the recharge component 
(table 7). The increase is due principally to the infiltration of delivered and applied surface water. The increased recharge is balanced by leakage to rivers $\left(1,051 \mathrm{ft}^{3} / \mathrm{s}\right)$, leakage to drains $\left(1,651 \mathrm{ft}^{3} / \mathrm{s}\right)$, and ground-water pumpage $\left(1,135 \mathrm{ft}^{3} / \mathrm{s}\right)$. Most of the increased recharge enters the overburden aquifer (about 3,083 $\mathrm{ft}^{3} / \mathrm{s}$ ) and a smaller amount enters the Saddle Mountains unit (about $444 \mathrm{ft}^{3} / \mathrm{s}$ ). Correspondingly, the largest increases in leakage to rivers and drains occur within these two units. Thus, these two units have been affected most by water development. The changes in recharge and leakage to rivers and drains for the Wanapum unit and the upper Grande Ronde are minor compared with those from the top two units. However, leakage to drains from the Wanapum unit has decreased by about $65 \mathrm{ft}^{3} / \mathrm{s}$, whereas this budget item increased for the rest of the system. This decrease represents a net loss of streamflow resulting from ground-water pumpage.

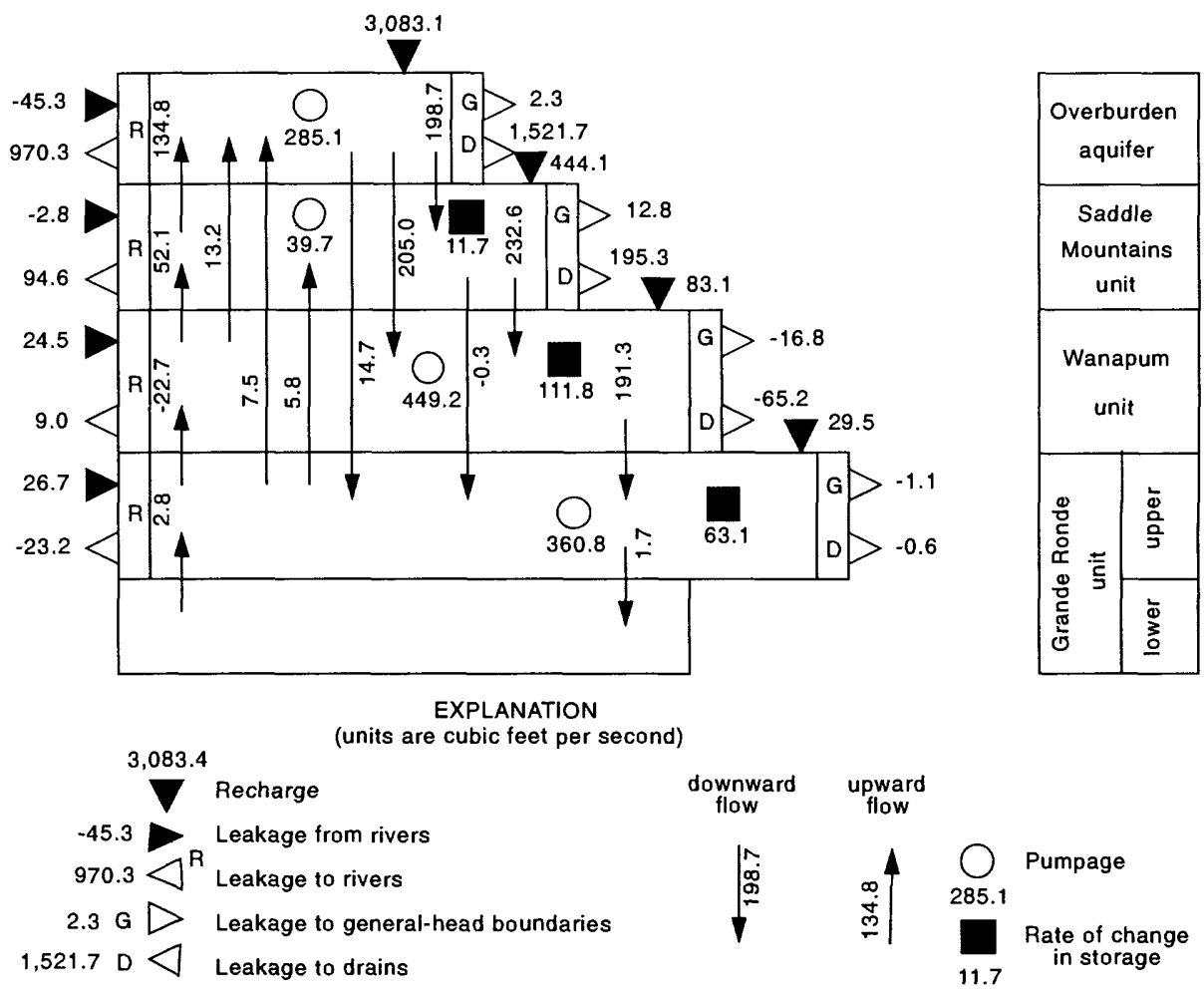

Figure 10.--Schematic diagram showing the model-calculated water budget change from predevelopment to time-averaged conditions.

The large changes in flow between layers (table 8) are due to the increased recharge (and thus higher heads) in the top two layers. Again, the largest changes are for the overburden aquifer and the Saddle Mountains unit. The Wanapum unit now receives four times more leakage from these units because they overlie the Wanapum unit in the areas with the largest increases in recharge. Thus, the largest changes in water-budget components for the Wanapum unit are increased leakage from the overlying units and the additional leakage to the upper Grande Ronde.

The spatial distribution of the above changes, combined with the effects of ground-water pumpage, has led to regional variations in water-level changes. The difference between model-calculated water levels for the time-averaged and predevelopment simulations is the regional estimate of water-level changes that have occurred as a result of water-development practices (plate 15). 
For the overburden aquifer, water levels rose an average of about $40 \mathrm{ft}$ (median rise of about $12 \mathrm{ft}$ ). The rises saturated about $16 \mathrm{mi}^{3}$ of sediments to a total of $169 \mathrm{mi}^{3}$ and increased its saturated area by about $1,600 \mathrm{mi}^{2}$ to a total of $4,509 \mathrm{mi}^{2}$. This amounts to an increase in water in storage of about $3 \mathrm{mi}^{3}$ (10 million acre-ft). These changes result from the increased recharge, which in turn is a result of the infiltration of applied surface water to croplands; the surface-water application rate averages about $4 \mathrm{ft} / \mathrm{yr}$ on the plateau. The largest changes occurred in the CBIP, where water-level rises range from 10 to $200 \mathrm{ft}$. Rises were not as large in the extensively surface-waterirrigated Yakima River basin because water levels were already near land surface and most of the overburden was saturated. Thus, most rises there are less than about $10 \mathrm{ft}$; natural and artificial drains discharge these rises. Waterlevel declines occurred only in a few locations within the overburden aquifer. The model indicates some localized declines, on the order of $10 \mathrm{ft}$, in the Wenas Creek valley (tributary to the Yakima River). Declines, as much as $40 \mathrm{ft}$, also are indicated along the eastern edge of the overburden aquifer in the Walla Walla River basin where the overburden aquifer is pumped. Throughout the remaining part of the Walla Walla River basin, there have been rises ranging from 5 to $30 \mathrm{ft}$.

Water levels have risen throughout much of the Saddle Mountains unit as they have in the overburden aquifer. These rises average about $65 \mathrm{ft}$ (a median of about $20 \mathrm{ft}$ ). The largest rises occurred within the lower CBIP north of Pasco, Wash., where rises exceeded $100 \mathrm{ft}$. Rises occurred throughout this unit where it underlies the valley floor in the Yakima River basin. Because the predevelopment water levels were near land surface, the rises have been smaller than those in the CBIP. Larger rises, as much as $100 \mathrm{ft}$ or so, occurred where the overburden aquifer is thin or absent along the peripheral edges and within tributary valleys of the Yakima River. Rises also occurred along the Columbia River in both Oregon and Washington between the Umatilla River and Willow Creek. Except for some effects of the dams along the Columbia River, the rises result from surface-water irrigation. The rises, in turn, saturated about $23 \mathrm{mi}^{3}$ of the unit, bringing the total to some $362 \mathrm{mi}^{3}$ (an increase of water in storage of about 1.6 million acre-ft) and increased its saturated area by about $839 \mathrm{mi}^{2}$ to a total of $5,748 \mathrm{mi}^{2}$. Relatively small and localized water-level declines occurred mainly in small valleys within the Yakima Fold Belt.

The general effect of water development on the upper two units has been to raise the water-level altitudes over most of their extent (plate 15c and d). Declines in these units were small and not widespread. This is because there is little pumpage from the Saddle Mountains unit to induce declines, and the pumpage from the overburden aquifer is generally in areas of surface-water irrigation where pumping withdraws stored water from irrigation recharge and captures water in streams, canals, and drains.

Water-level rises and declines in the Wanapum unit were much more widespread than in the upper two units (plate 15e). In areas of intensive surface-water use, such as the Yakima River valley, CBIP, and parts of Oregon between the Umatilla River and Willow Creek, water levels have risen. These rises average about $55 \mathrm{ft}$ (median of $10 \mathrm{ft}$ ) and range from 0 to about $300 \mathrm{ft}$ in the northwestern part of Quincy basin (see plate 15e). The area affected by rises is some $7,000 \mathrm{mi}^{2}$, although the area with rises greater than about $10 \mathrm{ft}$ is about $3,900 \mathrm{mi}^{2}$. Water-level rises are smaller where the regional drain altitudes are near the top of the Wanapum unit. Rises are larger in upland areas where the top of the Wanapum unit is above the altitude of the regional drains.

Water-level declines in the Wanapum unit occurred throughout about $13,400 \mathrm{mi}^{2}$ or 65 percent of the area; again, declines greater than about $10 \mathrm{ft}$ cover a smaller area of about $7,400 \mathrm{mi}^{2}$. Declines in the Wanapum unit average about $60 \mathrm{ft}$ (median value of about $9 \mathrm{ft}$ ) and range from 0 to more than $200 \mathrm{ft}$. The largest declines occur in the Odessa-Lind pumping center, within some of the valleys in the Yakima Fold Belt, on the south slope of Horse Heaven Hills, in the pumping center near Umatilla, Oreg., and in the Walla Walla River basin (plate 15c). In several of these areas, the declines were moderated by the rising water levels in nearby surface-water-irrigated areas. These rises increased gradient, and thus supply additional water to the pumping areas. A good example of this is the narrow transition zone between water-level rises in the CBIP and water-level declines beginning just east of the East Low Canal and extending into the Odessa-Lind area. Further, operation of the predevelopment model, but using the additional recharge resulting from the surface-water irrigation, indicated water-level rises of 10 to $100 \mathrm{ft}$ over a large part of the Odessa-Lind pumping center. Although there are only three wells within the Odessa-Lind area with water-level data prior to both the creation of CBIP and major ground-water pumping, the data from these wells indicate that water-level rises did occur. The calculated water-level declines are in general agreement with the more local or subregional studies cited at the beginning of this section. 
Water development raised and lowered the water levels about equally throughout the upper Grande Ronde. Rises averaged about $30 \mathrm{ft}$ (median of about $8 \mathrm{ft}$ ) and declines averaged about $35 \mathrm{ft}$ (median of about $6 \mathrm{ft}$ ).

Maximum-calculated rises and declines both exceed $200 \mathrm{ft}$. The rises occurred in the surface-water-irrigated areas and along the dammed parts of the major rivers. The largest rises occurred in the Quincy basin. Declines occurred in areas of ground-water pumpage, mainly centered in the Odessa-Lind area of Washington and the Umatilla area of Oregon. Smaller scale declines occurred in the Pullman, Wash.-Moscow, Idaho, area and in the Horse Heaven Hills area. Localized declines also occurred in various locations on the plateau.

The calculated declines and rises for the upper Grande Ronde are generally larger than those estimated in previous studies. Previous estimated declines generally were based on composite well data (there are no upper Grande Ronde wells with a long-time record of water-level data that penetrate its full thickness) and, thus, include head contributions from the higher head Wanapum unit. A piezometer in a test well in the Odessa area, which monitors the top part of the upper Grande Ronde, has shown water-level declines of more than $100 \mathrm{ft}$. These point data match the model-calculated declines quite well. However, no areal inferences of declines can be derived from this single well data set. Several recently completed wells, drilled and cased through the Wanapum unit, indicate much larger head declines in the upper Grande Ronde than those inferred from composite well information. Thus, lack of observational data precludes verification of the declines. Still, the match between calculated and observed heads indicates that the calculated declines are reasonable. Indeed, this type of analysis was a major objective in constructing the model.

Projected rises and declines in the lower Grande Ronde cannot be verified because there are no data available. The calculated water-level changes are considered a first estimate of the effects of water development in the deep system. The largest calculated rises are in the Quincy basin, on the order of $150 \mathrm{ft}$. Smaller rises are indicated in other surface-water-irrigated areas and along the major rivers. Declines of as much as $170 \mathrm{ft}$ are calculated for the Odessa-Lind area, and declines of as much as $50 \mathrm{ft}$ are calculated for the Umatilla area. The distribution of rises and declines for the lower Grande Ronde are similar to those for the upper Grand Ronde but are smaller. Like the upper Grande Ronde, declines in the lower Grande Ronde have spread north and east from the Odessa-Lind area, and the southern extent of declines is truncated by the narrow east-west strip of low conductivity discussed in previous sections.

The effects of water development also are shown by the changes in ground-water discharge within the 27 selected basins (table 9). Calculated discharge decreased in 17 basins; the decreases ranged from 0.1 to $38.2 \mathrm{ft}^{3} / \mathrm{s}$. The ground-water discharge in the remainder of the basins was either about the same or larger when compared to the steady-state (predevelopment) results. The basins with the largest decreases were Crab Creek, Little Klickitat River, Cow Creek, Touchet River, Bowers Coulee, and Douglas Creek basins. For example, ground-water discharge in Cow Creek basin decreased from about $41 \mathrm{ft}^{3} / \mathrm{s}$ under predevelopment conditions to about $23 \mathrm{ft}^{3} / \mathrm{s}$ under current conditions. Similarly, the discharge in Crab Creek basin decreased by about $38 \mathrm{ft}^{3} / \mathrm{s}$, from 63 to $25 \mathrm{ft}^{3} / \mathrm{s}$. Several of the basins have seen increases in ground-water discharge, although only Glade Creek had a relatively large model-calculated percentage of increase. In this basin, model-estimated ground-water discharge increased from less than $1 \mathrm{ft}^{3} / \mathrm{s}$ to about $8 \mathrm{ft}^{3} / \mathrm{s}$. Had basins with extensive surface-water irrigation been analyzed, such as the Toppenish Creek basin, they would show large percentages of increases in ground-water discharge.

The calculated ground-water discharge to 7 of the 16 selected stream reaches significantly increased because of water development (table 10). Unlike the analysis of the basins, the stream reaches had no significant decreases in ground-water discharge. However, decreases in discharge to streams occurred for the selected basins analyzed and for some of the drain cells not included in one of the 27 basins. The seven reaches with increased ground-water discharge are the upper Columbia River, the lower and upper Yakima River, the lower Crab Creek, the Walla Walla River, the Naches River, and the Rocky Ford-Crab Creek.

The upper Columbia River receives an additional $540 \mathrm{ft}^{3} / \mathrm{s}$ of ground-water discharge compared with predevelopment conditions. This increase is due to the rise in water levels in CBIP. This quantity is insignificant when compared to the flow in the Columbia River. The upper Yakima River receives about 64 percent more ground-water discharge $\left(118 \mathrm{ft}^{3} / \mathrm{s}\right)$ than under predevelopment conditions and, in the lower Yakima River, ground-water discharge has increased by an order of magnitude $\left(379 \mathrm{ft}^{3} / \mathrm{s}\right)$. Thus, the Yakima River receives about 
$500 \mathrm{ft}^{3} / \mathrm{s}$ more ground-water discharge than under predevelopment conditions. This is due to the irrigation return flows resulting from the infiltration of excess applied surface water. Much of this excess water flows through the overburden aquifer to drains that discharge to the Yakima River; the flow to drains is not included in the $500 \mathrm{ft}^{3} / \mathrm{s}$. The $500 \mathrm{ft}^{3} / \mathrm{s}$ is relied upon for meeting downstream water rights. Lower Crab Creek receives an additional $69 \mathrm{ft}^{3} / \mathrm{s}$ of ground-water discharge, as calculated by the model. The increase is irrigation return flow from both CBIP and discharge of the rising water levels in the Wanapum unit. Lower Crab Creek parallels the base of the north slope of the Saddle Mountains anticline and discharges to the Columbia River. The creek is near bank full in this area during the summer irrigation season. The Walla Walla River has a calculated increase of about $43 \mathrm{ft}^{3} / \mathrm{s}$, resulting from the use of surface water. The calculated ground-water discharge to the Naches River increased from about 55 to $98 \mathrm{ft}^{3} / \mathrm{s}$ due to surface-water irrigation. Last, the Rocky Ford-Crab Creek area (defined by the area around Potholes Reservoir) has a calculated increase of about $80 \mathrm{ft}^{3} / \mathrm{s}\left(91 \mathrm{ft}^{3} / \mathrm{s}\right.$ compared to $11 \mathrm{ft}^{3} / \mathrm{s}$ for predevelopment conditions). Again, this increased discharge is due to the delivery/leakage and application of surface water in the CBIP. Each of these seven stream reaches crosses the areas of calculated water-level rises caused by the infiltration of surface water applied to croplands. These infiltration quantities (estimated with the deep percolation model and discussed previously in the "Recharge" subsection) include delivery (canal) losses.

The simulated magnitudes of the changes in water levels and ground-water discharge are reasonable when compared with observed changes. Therefore, the effects of water development on the regional aquifer system presented in this section are believed to be the best regional estimates available. The effects also occur in some areas that have not been monitored, thus indicating that some type of observation well network might be needed in these areas. 


\section{SUMMARY AND CONCLUSIONS}

A study of the Columbia Plateau regional aquifer system began in October 1982 as part of the U.S. Geological Survey's Regional Aquifer-System Analysis Program. The goal of the study was to provide information to aid in the effective management of this important ground-water resource. A numerical model was constructed to help develop an understanding of the regional ground-water flow system and the relation among the water-budget components of the system. This report describes the hydrogeologic framework for model construction, the pumpage from and the recharge to the system, the calibration of the model, the hydrology of the regional aquifer system on the basis of model simulations for predevelopment and current (1983-85) conditions, and the model-calculated effects of water development.

The aquifer system underlies about $32,688 \mathrm{mi}^{2}$ within the ground-water model boundaries and is composed of basalts of Miocene age with relatively minor amounts of interbedded sediments and overlying sediments of Miocene to Holocene age. These rock materials have been divided for study purposes into seven units. These units are the overburden aquifer, the Saddle Mountains unit, the Saddle Mountains-Wanapum interbed/confining unit, the Wanapum unit, the Wanapum-Grande Ronde interbed/confining unit, the Grande Ronde unit, and the basement confining unit. The Grande Ronde unit was divided further into two layers, the upper and lower Grande Ronde, for the construction of the model.

The overburden aquifer consists of unconsolidated sediments and underlies about 4,509 $\mathrm{mi}^{2}$, in which it encompasses some $169 \mathrm{mi}^{3}$ of sediments. The average cell thickness of the overburden is about $260 \mathrm{ft}$ (median of $190 \mathrm{ft}$ ) and thickness ranges from about $30 \mathrm{ft}$ to $1,200 \mathrm{ft}$. The Saddle Mountains unit underlies about $5,748 \mathrm{mi}^{2}$, in which it encompasses some $362 \mathrm{mi}^{3}$ of rock material; the cell thickness averages about $410 \mathrm{ft}$ (median of $370 \mathrm{ft}$ ) and ranges from $20 \mathrm{ft}$ to $1,300 \mathrm{ft}$. The Wanapum unit underlies about $20,540 \mathrm{mi}^{2}$ in the model boundaries where it encompasses some $1,700 \mathrm{mi}^{3}$ of saturated rock material. The Wanapum unit cell thickness ranges from 30 to $1,650 \mathrm{ft}$ and averages about $570 \mathrm{ft}$ (median of $530 \mathrm{ft}$ ). The upper Grande Ronde underlies $32,500 \mathrm{mi}^{2}$ of the modeled area and has a volume of about $10,550 \mathrm{mi}^{3}$. This unit has an average cell thickness of about $1,700 \mathrm{ft}$ (median of 2,000 ft) and the cell thickness ranges from $100 \mathrm{ft}$ to 3,000 ft. The lower Grande Ronde underlies about $20,110 \mathrm{mi}^{2}$, and using the estimated thickness derived during this study, it includes about $13,400 \mathrm{mi}^{3}$ of basalt. As estimated, this thickness averages $3,500 \mathrm{ft}$ (median of 2,800 ft) and ranges from $200 \mathrm{ft}$ to $16,300 \mathrm{ft}$.

Hydraulic characteristics of the units initially were estimated on the basis of specific-capacity information, previously published data, and completed and ongoing investigations. These data enabled a statistical characterization of the hydraulic characteristics. The data then were used to obtain initial estimates for the model calibration.

The major hydrologic stresses to the aquifer system, ground-water pumpage and ground-water recharge, were estimated independently of the model. Average ground-water pumpage for the period spring 1983 to spring 1985 was estimated as about $1,135 \mathrm{ft}^{3} / \mathrm{s}$. About $285 \mathrm{ft}^{3} / \mathrm{s}$ is withdrawn from the overburden aquifer, $40 \mathrm{ft}^{3} / \mathrm{s} \mathrm{from} \mathrm{the}$ Saddle Mountains unit, $449 \mathrm{ft}^{3} / \mathrm{s}$ from the Wanapum unit, and $361 \mathrm{ft}^{3} / \mathrm{s}$ from the upper Grande Ronde. There is no pumpage from the lower Grande Ronde. Recharge was estimated on the basis of the average of calculated daily values of deep percolation for 53 zones within the study area. Daily values were calculated for discrete cells for each zone using an energy-soil-water balance model. The zones included most of the irrigated croplands and the areas receiving less than $11 \mathrm{in} / \mathrm{yr}$ of precipitation. Recharge was estimated for the remainder of the area in the ground-water model boundaries (outside of the zones) through the use of a regression equation that relates mean annual recharge to mean annual precipitation. The estimates of recharge were derived for both predevelopment and current (1980's) land-use conditions. The long-term, time-averaged estimate of recharge within the ground-water model boundary for predevelopment conditions is $6,566 \mathrm{ft}^{3} / \mathrm{s}$ and for current conditions is $10,205 \mathrm{ft}^{3} / \mathrm{s}$. The net change, $3,639 \mathrm{ft}^{3} / \mathrm{s}$, is due to water-management activities--principally surface-water irrigation.

The flow system in the Columbia Plateau aquifer was simulated using a five-layer, finite-difference numerical model. The model was constructed and calibrated to simulate flow for predevelopment (steady-state) and time-averaged (1983-85) aquifer conditions. The aquifer system was discretized with a rectangular grid system 
based on latitude and longitude. Each cell of the grid system was about $1.5 \mathrm{mi}$ in longitude and $2.8 \mathrm{mi}$ in latitude. The overburden aquifer was discretized into 969 cells; about 345 of these were estimated to be unsaturated for the steady-state/predevelopment simulation. The Saddle Mountains unit, layer 2, was discretized into 1,229 cells; about 180 of these were estimated to be unsaturated during predevelopment times. The Wanapum unit, layer 3, was discretized into 4,414 cells. The upper Grande Ronde, layer 4, was discretized into 6,977 cells and the lower Grande Ronde into 4,310 cells.

Boundary conditions defined for the five layers were either no-flow or seepage-face boundaries. The seepage-face boundaries were modeled as a general head boundary (GHB); there were $560 \mathrm{GHB}$ cells.

The model first was calibrated to steady-state conditions using the initial estimates of hydraulic characteristics, pre-dam elevations for the stage of surface-water features, and the estimates of recharge for predevelopment land-use conditions. After calibrating to a coarse estimate of the predevelopment head configurations, the model was calibrated to time-averaged conditions. The predevelopment model then was operated with the derived hydraulic characteristics. The calculated water levels and water budget were assumed to be the best estimate of the predevelopment system. Last, the water budget and calculated heads for the two simulations were compared to see the effects of water development.

Model-derived values of lateral hydraulic conductivity for the overburden ranged from about $5 \times 10^{-7}$ to $12.7 \times 10^{-3} \mathrm{ft} / \mathrm{s}$ and had a median of about $5 \times 10^{-4} \mathrm{ft} / \mathrm{s}$. The model-derived values for the basalt units ranged from about $1 \times 10^{-6}$ to $1 \times 10^{-4} \mathrm{ft} / \mathrm{s}$ and had a median value of about $1.7 \times 10^{-5} \mathrm{ft} / \mathrm{s}$. This median value is at about the $30 \mathrm{th}$ percentile of the calculated basalt specific-capacity values. Transmissivity values for the overburden aquifer ranged from about $2.6 \times 10^{-5}$ to $3.1 \mathrm{ft}^{2} / \mathrm{s}$ and had a median of about $5.8 \times 10^{-2} \mathrm{ft}^{2} / \mathrm{s}$. Basalt transmissivities ranged from about $2.8 \times 10^{-5}$ to $4.8 \times 10^{-1} \mathrm{ft}^{2} / \mathrm{s}$. Median values of transmissivities for the basalt units, from layer 2 to layer 5 , were $3.7 \times 10^{-3}, 8.5 \times 10^{-3}, 1.97 \times 10^{-2}$, and $3.1 \times 10^{-2} \mathrm{ft}^{2} / \mathrm{s}$, respectively. The transmissivity over the complete saturated thickness of the aquifer system ranged from $4.8 \times 10^{-4}$ to $3.5 \mathrm{ft}^{2} / \mathrm{s}$, median of $3.8 \times 10^{-2} \mathrm{ft}^{2} / \mathrm{s}$. Model-derived vertical hydraulic conductance for all units ranged from $4.5 \times 10^{-13}$ to $1.0 \times 10^{-5} 1 / \mathrm{s}$. Median values for the connections between layers were, top to bottom, $2.6 \times 10^{-8}, 2.1 \times 10^{-11}, 6.0 \times 10^{-12}$, and $5.0 \times 10^{-11} 1 / \mathrm{s}$, respectively. The storage cocfficient used for the change in storage for the time-averaged simulation was 0.04 for the basalt units; this term was assumed to be negligible for the overburden aquifer.

Major rivers were simulated using 591 river cells; 2,841 drain cells were used to simulate smaller streams, coulees, lakes, and farm drains. The stream-leakage coefficients ranged from 0.5 to $11.0 \mathrm{ft}^{2} / \mathrm{s}$ and had a median of $1.0 \mathrm{ft}^{2} / \mathrm{s}$. The drain-leakage coefficients ranged from 0.1 to $10.0 \mathrm{ft}^{2} / \mathrm{s}$ and had a median of $1.0 \mathrm{ft}^{2} / \mathrm{s}$. These leakage coefficients represent regionalized values.

The mean residual (MR), mean absolute residual (MAR), and root-mean-square (RMS) values of the time-averaged simulation calibration fit for the overburden aquifer were $-18,46$, and $71 \mathrm{ft}$, respectively. The MR, MAR, and RMS values were -14, 72, and $104 \mathrm{ft}$ for the Saddle Mountains unit and $-31,81$, and $124 \mathrm{ft}$ for the Wanapum unit. The upper Grande Ronde unit values were -122, 184, and $292 \mathrm{ft}$, respectively. No estimates were made for the lower Grande Ronde unit due to lack of water-level data. The model reasonably simulates the estimated head surfaces; figures presenting selected observed and calculated water-level contours show the goodness-of-fit. Accuracy of calculated water levels is diminished in the steep terrain areas, where lateral head changes can approach $600 \mathrm{ft}$ over a model cell. RMS residuals for cells with observation wells were, from layer 1 to layer $4,58,91,142$, and $253 \mathrm{ft}$, respectively.

On the basis of predevelopment model results, the largest water-budget inflow component is recharge, $6,567 \mathrm{ft}^{3} / \mathrm{s}$. The only other inflow is leakage from rivers, $554 \mathrm{ft}^{3} / \mathrm{s}$. Predevelopment discharge from the aquifer system occurred principally as leakage to drains $\left(3,945 \mathrm{ft}^{3} / \mathrm{s}\right)$ and rivers $\left(2,754 \mathrm{ft}^{3} / \mathrm{s}\right)$ and secondarily as discharge to seepage-face boundaries (GHBs), $425 \mathrm{ft}^{3} / \mathrm{s}$. About 63 percent of the recharge $\left(4,131 \mathrm{ft}^{3} / \mathrm{s}\right)$ entered the upper Grande Ronde, 33 percent $\left(2,185 \mathrm{ft}^{3} / \mathrm{s}\right)$ entered the Wanapum unit, and the remaining 4 percent entered the overburden aquifer and the Saddle Mountains unit. Leakage to drains occurred principally from the upper Grande Ronde $\left(2,889 \mathrm{ft}^{3} / \mathrm{s}\right)$ and from the Wanapum unit $\left(878 \mathrm{ft}^{3} / \mathrm{s}\right)$. Leakage to rivers occurred from the upper Grande Ronde $\left(1,139 \mathrm{ft}^{3} / \mathrm{s}\right)$, the overburden aquifer $\left(912 \mathrm{ft}^{3} / \mathrm{s}\right)$, the Wanapum unit $\left(522 \mathrm{ft}^{3} / \mathrm{s}\right)$, and the Saddle Mountains unit 
$\left(180 \mathrm{ft}^{3} / \mathrm{s}\right)$. Thus, about 60 percent more water discharges through the overburden aquifer than it receives from recharge and leakage from rivers. This is water moving upward from the basalts into the overburden aquifer in localized areas of upward vertical gradients.

On the basis of time-averaged model results, the inflow into the aquifer system is $10,948 \mathrm{ft}^{3} / \mathrm{s}$. Of this inflow, $10,205 \mathrm{ft}^{3} / \mathrm{s}$ is recharge, $557 \mathrm{ft}^{3} / \mathrm{s}$ is leakage from rivers, and $187 \mathrm{ft}^{3} / \mathrm{s}$ is the change in storage due to water-level declines. Discharge from the system is through rivers $\left(5,596 \mathrm{ft}^{3} / \mathrm{s}\right)$, drains $\left(3,805 \mathrm{ft}^{3} / \mathrm{s}\right)$, ground-water pumpage $\left(1,135 \mathrm{ft}^{3} / \mathrm{s}\right)$, and leakage to GHBs $\left(423 \mathrm{ft}^{3} / \mathrm{s}\right)$. Recharge enters the aquifer system principally through the upper Grande Ronde $\left(4,161 \mathrm{ft}^{3} / \mathrm{s}\right)$, the overburden aquifer $\left(3,202 \mathrm{ft}^{3} / \mathrm{s}\right)$, and the Wanapum unit $\left(2,268 \mathrm{ft}^{3} / \mathrm{s}\right)$. Only 6 percent of the recharge $\left(577 \mathrm{ft}^{3} / \mathrm{s}\right)$ enters through the Saddle Mountains unit. Discharge as leakage to drains is principally from the upper Grande Ronde $\left(2,888 \mathrm{ft}^{3} / \mathrm{s}\right)$ and the overburden aquifer $\left(1,670 \mathrm{ft}^{3} / \mathrm{s}\right)$ and secondarily from the Wanapum $\left(812 \mathrm{ft}^{3} / \mathrm{s}\right)$, and Saddle Mountains $\left(225 \mathrm{ft}^{3} / \mathrm{s}\right)$ units. Similarly, discharge as leakage to rivers is mainly from the upper Grande Ronde $\left(1,116 \mathrm{ft}^{3} / \mathrm{s}\right)$ and the overburden aquifer $\left(1,882 \mathrm{ft}^{3} / \mathrm{s}\right)$. The Wanapum and Saddle Mountains units have a combined total of $806 \mathrm{ft}^{3} / \mathrm{s}$ of discharge to rivers. Ground-water pumpage from layers 1 through 4 averages $285,40,449$, and $361 \mathrm{ft}^{3} / \mathrm{s}$, respectively.

The major influences of water-management practices on the aquifer system are ground-water pumpage and subsequent irrigation of croplands, surface-water delivery and application for irrigation, construction of dams, and changing land uses. The effects of water development caused by the infiltration of irrigation water have been to increase recharge by about $3,640 \mathrm{ft}^{3} / \mathrm{s}$ and to saturate large areas of previously unsaturated overburden aquifer and Saddle Mountains unit. The increased recharge has been balanced by leakage to drains $\left(1,651 \mathrm{ft}^{3} / \mathrm{s}\right)$, ground-water pumpage $\left(1,135 \mathrm{ft}^{3} / \mathrm{s}\right)$, and leakage to rivers $\left(1,051 \mathrm{ft}^{3} / \mathrm{s}\right)$. Much of the increased recharge enters the overburden aquifer in the Columbia Basin Irrigation Project and the Yakima River basin. This increased recharge has caused water-level rises as much as $200 \mathrm{ft}$ in that unit and, additionally, water-level rises in all other units. Ground-water pumpage has caused water-level declines over a large area in the central plateau in Washington and in localized areas near pumping centers in Oregon. Declines have averaged $50 \mathrm{ft}$ and range from 0 to more than $200 \mathrm{ft}$.

The predevelopment and time-averaged models provide the basis for a description of the regional flow system. The information available from the model calculations can be used to estimate lateral and vertical head variations, movement of water between study units, location and magnitude of discharge, effects of water development, and the relation between water-budget components of the system and how the relations changed with time. Together, the models provide an understanding of the regional ground-water flow system. The models have the capability to provide boundary conditions for local, subregional-scale modeling studies within acceptable limits. This includes information for the deeper parts of the aquifer system, which is otherwise unavailable. The model can be used to estimate the regional effects of potential future water-management strategies under the assumption of invariant climate (recharge from precipitation does not change) and, except for the potential future strategies, invariant (calibrated to) water-development practices. 


\section{SELECTED REFERENCES}

Barker, R.A., 1979, Computer simulation and geohydrology of a basalt aquifer system in the Pullman-Moscow basin, Washington and Idaho: Washington State Department of Ecology, Water-Supply Bulletin 45, 119 p.

Barker, R.A., and MacNish, R.D., 1976, Digital model of the gravel aquifer, Walla Walla River Basin, Washington and Oregon: Washington Department of Ecology Water-Supply Bulletin 45, 49 p.

Bauer, H.H., Vaccaro, J.J., and Lane, R.C., 1985, Maps showing ground-water levels in the Columbia River Basalt and overlying material, spring 1983, southeastern Washington: U.S. Geological Survey Water-Resources Investigations Report 84-4360, 4 sheets.

Bauer, H.H., and Vaccaro, J.J., 1987, Documentation of a deep percolation model for estimating ground-water recharge: U.S. Geological Survey Open-File Report 86-536, 180 p.

1990, Estimates of ground-water recharge to the Columbia Plateau regional aquifer system, Washington, Oregon, and Idaho, for predevelopment and current land-use conditions: U.S. Geological Survey Water-Resources Investigations Report 88-4108, 37 p., 2 plates.

Bear, J., 1979, Hydraulics of ground water: New York, McGraw-Hill Inc., 569 p.

Bierschenk, W.H., 1959, Aquifer characteristics and ground-water movement at Hanford: unclassified AEC Research and Development report, p. 33.

Bennett, G.D., Kontis, A.L., and Larson, S.P., 1982, Representation of multiaquifer well effects in three-dimensional ground-water flow simulation: Ground Water, v. 20, no. 3, p. 334-341.

Bolke, E.L., and Skrivan, J.A., 1981, Digital-model simulation of the Toppenish alluvial aquifer, Yakima Indian Reservation, Washington: U.S. Geological Survey Water-Resources Investigations, Open-File Report 81-425, $34 \mathrm{p}$.

Bolke, E.L., and Vaccaro, J.J., 1981, Digital-model simulation of the hydrologic flow system, with emphasis on ground water in the Spokane Valley, Washington and Idaho: U.S. Geological Survey Water-Resources Investigations, Open-File Report 80-1300, 43 p.

Bush, P.W., and Johnston. R.H., 1988, Ground-water hydraulics, regional flow, and ground-water development of the Floridan aquifer system in Florida and in parts of Georgia, South Carolina, and Alabama: U.S. Geological Survey Professional Paper 1403-C, 80 p.

Camp, V.E., Hooper, P.R., Swanson, D.A., and Wright, T.L., 1982, Columbia River Basalt in Idaho: physical and chemical characteristics, flow distribution, and tectonic implications, in B. Bonnichsen and R.M. Breckenridge, eds., Cenozoic Geology of Idaho: Idaho Bureau of Mines and Geology, Bulletin 26, p. 55-75.

Cline, D.R., 1984, Ground-water levels and pumpage in east-central Washington, including the Odessa-Lind area, 1967 to 1981: Washington State Department of Ecology, Water-Supply Bulletin no. 55, 34 p.

Cline, D.R., and Collins, C.A., 1992, Ground-water pumpage in the Columbia Plateau, Washington and Oregon, 1945 to 1984: U.S. Geological Survey Water-Resources Investigations Report 90-4085, 33 p.

Cline, D.R., and Knadle, M.E., 1990, Ground-water pumpage from the Columbia Plateau regional aquifer system, Washington, 1984: U.S. Geological Survey Water-Resources Investigations Report 87-4135, 18 p., 1 sheet. 


\section{SELECTED REFERENCES--Continued}

Collins, C.A., 1987, Ground-water pumpage from the Columbia Plateau regional aquifer system, Oregon, 1984: U.S. Geological Survey Water-Resources Investigations Report 86-4211, 21 p.

Davies-Smith, A., Bolke, E.L., and Collins, C.A., 1988, Geohydrology and digital simulation of the ground-water flow system in the Umatilla Plateau and Horse Heaven Hills area, Oregon and Washington: U.S. Geological Survey Water-Resources Investigations Report 87-4268, 71 p.

Downey, J.S., 1986, Geohydrology of bedrock aquifers in the northern Great Plains in parts of Montana, North Dakota, South Dakota, and Wyoming: U.S. Geological Survey Professional Paper 1402-E, 87 p.

Drost, B.W., and Whiteman, K.J., 1986, Surficial geology, structure, and thickness of selected geohydrologic units in the Columbia Plateau, Washington: U.S. Geological Survey Water-Resources Investigations Report 84-4326, 10 sheets.

Drost, B.W., Whiteman, K.J., and Gonthier, J.B., 1990, The geologic framework of the Columbia Plateau regional aquifer system, Washington, Oregon, and Idaho: U.S. Geological Survey Water-Resources Investigations Report 87-4238, 10 p., 10 sheets.

Eddy, P.A., 1976, Description, preliminary results, and pumping tests--observation well 13 near George, Washington: Washington Department of Ecology Water-Resources Information Series, Technical Bulletin 19, 43 p.

Elassal, A.A., and Caruso, V.M., 1983, U.S. Geological Survey digital cartographic data schedules: Digital elevation models: U.S. Geological Survey Circular 895-B, 40 p.

Farooqui, S.M., Beaulieu, J.B., Bunker, R.C., Stensland, D.E., and Thoms, R.E., 1981, Dalles Group: Neogene formations overlying the Columbia River Basalt Group in north-central Oregon: Oregon Department of Geology and Mineral Industries, Oregon Geology, v. 43, no. 10, p. 131-140.

Ferris, J.G., Knowles, D.B., Brown, R.H., and Stallman, R.W., 1962, Theory of aquifer test: U.S. Geological Survey Water-Supply Paper 1536-E, $174 \mathrm{p}$.

Flint, R.F., 1938, Origin of the Cheney-Palouse scabland tract: Geological Society of America Bulletin, v. 49, p. 461-523.

Freeman, O.W., Forrester, J.O., and Lupher, R.L., 1945, Physiographic divisions of the Columbia Intermontane Province: Annual Association American Geographer, v. 35, no. 2, p. 50-75.

Freeze, R.A., and Cherry, J.A., 1979, Groundwater: Englewood Cliffs, New Jersey, Prentice-Hall, Inc., 604 p.

Garabedian, S.P., 1986, Application of a parameter-estimation technique to modeling the regional aquifer underlying the Eastern Snake River Plain, Idaho: U.S. Geological Survey Water-Supply Paper 2278, 60 p., 4 plates.

Gonthier, J.B., 1990, Geology, structure, and thickness of hydrogeologic units in part of the Columbia Plateau, Oregon: U.S. Geological Survey Water-Resources Investigations Report 86-4001, 6 sheets.

Hansen, A.J., 1993a, Modifications to the modular three-dimensional finite-difference ground-water flow model used for the Columbia Plateau regional aquifer-system analysis, Washington, Oregon, and Idaho: U.S. Geological Survey Open-File Report 91-532, 162 p. 


\section{SELECTED REFERENCES--Continued}

1993b, Archiving of source code for the finite-difference flow model and the post-processors and input and output files for the Columbia Plateau regional aquifer system, Washington, Oregon, and Idaho: U.S. Geological Survey Open-File Report 90-364, 9 p.

Hooper, P.R., 1982, The Columbia River Basalts: Science, v. 215, no. 4,539, p. 1,463-1,468.

IMSL, 1982, Interpolation, chapter I, in International mathematics and science library reference manual, v. 2: Houston, Texas, IMSL, Inc.

Jacob, C.E., 1940, On the flow of water in an elastic artesian aquifer: Transactions of the American Geophysical Union, v. 21 , pt. 2, p. 574-586.

Lane, R.C., and Whiteman, K.J., 1989, Ground-water levels, spring 1985, and ground-water level changes, spring 1983 to spring 1985, in three basalt units underlying the Columbia Plateau, Washington and Oregon: U.S. Geological Survey Water-Resources Investigations Report 88-4018, 4 sheets.

La Sala, A.M., Jr., and Doty, G.C., 1971, Preliminary evaluation of hydrologic factors related to radioactive waste storage in basaltic rocks at the Hanford Reservation, Washington: U.S. Geological Survey Open-File Report, $68 \mathrm{p}$.

Lohman, S.W., and others, 1972, Definitions of selected ground-water terms--revisions and conceptual refinements: U.S. Geological Survey Water-Supply Paper 1988, 21 p.

Luckey, R.R., Gutentag, E.D., Heimes, F.J., and Weeks, J.B., 1986, Digital simulation of ground-water flow in the High Plains Aquifer in parts of Colorado, Kansas, Nebraska, New Mexico, Oklahoma, South Dakota, Texas, and Wyoming: U.S. Geological Survey Professional Paper 1400-D, 57 p.

Lum, W.E., Smoot, J.L., and Ralston, D.R., 1990, Geohydrology and numerical model analysis of ground-water flow in the Pullman-Moscow area, Washington and Idaho: U.S. Geological Survey Water-Resources Investigations Report 89-4103, 73 p.

Luzier, J.E., and Skrivan, J.A., 1975, Digital simulation and projection of water-level declines in basalt aquifers of the Odessa-Lind area, east-central Washington: U.S. Geological Survey Open-File Report, 56 p.

Mackin, J.H., 1955, Geology of the Priest Rapids hydroelectric development, in Grant County Public Utility District No. 2, Priest Rapids hydroelectric development, Columbia River, Washington, v. 3 - appendices to v. 2, sec. A Geology and Construction Materials, $38 \mathrm{p}$.

MacNish, R.D., and Barker, R.A., 1976, Digital simulation of a basalt aquifer system, Walla Walla River basin, Washington and Oregon: Washington Department of Ecology Water-Supply Bulletin 44, 51 p.

McCuen, R.H., and Snyder, W.M., 1986, Hydrologic modeling: Englewood Cliffs, New Jersey, Prentice-Hall, 568 p.

McDonald and Harbaugh, 1988, A modular three-dimensional finite-difference ground-water flow model: U.S. Geological Survey Techniques of Water-Resources Investigations, Book 6, Chap. A1, 14 chaps.

Myers, C.W., and Price, S.M., 1979, Geologic studies of the Columbia Plateau, a status report: Rockwell International, Rockwell Hanford Operations RHO-BWI-ST-4, 520 p.

1981, Subsurface geology of the Cold Creek Syncline: Rockwell International, Rockwell Hanford Operations, RHO-BWI-ST-14, Richland, Washington, $380 \mathrm{p}$. 


\section{SELECTED REFERENCES--Continued}

Nelson, L.M., 1991, Surface-water resources for the Columbia Plateau, southeastern Washington, northeastern Oregon, and northwestern Idaho: U.S. Geological Survey Water-Resources Investigations Report 88-4105, 4 sheets.

Neuzil, C.E., 1986, Ground-water flow in low-permeability environments: Water-Resources Research, v. 22, no. 8 , p. 1,163-1,195.

Newcomb, R.C., 1958, Ringold Formation for Pleistocene age in type locality, the White Bluffs, Washington: American Journal of Science, v. 259, p. 328.

1961, Storage of ground water behind subsurface dams in Columbia River Basalt, Washington, Oregon, and Idaho: U.S. Geological Survey Professional Paper 383-A, 15 p.

1965, Geology and ground-water resources of the Walla Walla River Basin, Washington-Oregon:

Water-Supply Bulletin 21, Washington State Division of Water Resources, Olympia, Washington, 151 p.

1969, Effect of tectonic structure on the occurrence of ground water in the basalt of the Columbia River

Group of The Dalles Area, Oregon and Washington: U.S. Geological Survey Professional Paper 383-C, 33 p.

Newcomb, R.C., Strand, J.R., and Frank, F.J., 1972, Geology and ground-water characteristics of the Hanford Reservation of the U.S. Atomic Energy Commission, Washington: U.S. Geological Survey Professional Paper 717, 78 p.

Price, C.E., 1960, Artificial recharge of a well tapping basalt aquifers, Walla Walla area, Washington: Washington Division of Water Resources, Water-Supply Bulletin 7, $50 \mathrm{p}$.

Prych, E.A., 1983, Numerical simulation of ground-water flow in lower Satus Creek Basin, Yakima Indian Reservation, Washington: U.S. Geological Survey Water-Resources Investigations Report 82-4065, 78 p.

Raymond, J.R., and Tillson, D.D., 1968, Evaluation of a thick basalt sequence in south-central Washington BNWL-776: Pacific Northwest Laboratory, Battelle Memorial Institute, 120 p.

Reidel, S.P., 1982, Stratigraphy of the Grande Ronde Basalt, Columbia River Basalt Group, from the lower Salmon River and northern Hells Canyon area, Idaho, Oregon, and Washington, in Bill Bonnichsen and R.M.

Breckenridge, eds., Cenozoic geology of Idaho: Idaho Bureau of Mines and Geology Bulletin 26, p. 77-101.

Skrivan, J.A., 1987, Ground-water hydrology of the Toppenish Creek basin, Yakima Indian Reservation, Washington: U.S. Geological Survey Water-Resources Investigations Report 82-4010, 47 p.

Steinkampf, W.C., 1989, Water-quality characteristics of the Columbia Plateau regional aquifer system in parts of Washington, Oregon, and Idaho: U.S. Geological Survey Water-Resources Investigations Report 85-4048, $37 \mathrm{p}$.

Swanson, D.A., Wright, T.L., and Helz, R.T., 1975, Linear vent systems and estimated rates of magma production and eruption for the Yakima Basalt on the Columbia Plateau: American Journal of Science, v. 275, Oct. 1975, p. 877-905.

Swanson, D.A., and Wright, T.L., 1978, Bedrock geology of the southern Columbia Plateau and adjacent areas, chap. 3, in V.R. Baker and D. Nummedal, eds., The channeled scabland: Planetary Geology Program, National Aeronautical and Space Administration, Washington, D.C., p. 37-57. 


\section{SELECTED REFERENCES--Continued}

Swanson, D.A., Anderson, J.L., Bentley, R.D., Byerly, G.R., Camp, B.E., Gardner, J.N., and Wright, T.L., 1979a, Reconnaissance geologic map of the Columbia River Basalt Group in eastern Washington and northern Idaho: U.S. Geological Survey Open-File Report 79-1363, 26 p., scale 1:250,000, 12 sheets.

Swanson, D.A., Brown, J.C., Anderson, J.L., Bentley, R.D., Byerly, G.R., Gardner, J.N., and Wright, T.L., 1979b, Preliminary structure contour maps on the top of the Grande Ronde and Wanapum Basalts, eastern Washington and northern Idaho: U.S. Geological Survey Open-File Report 79-1364, scale 1:500,000, 2 sheets.

Swanson, D.A., Wright, T.L., Hooper, P.R., and Bentley, R.D., 1979c, Revisions in stratigraphic nomenclature of the Columbia River Basalt Group: U.S. Geological Survey Bulletin 1457-G, 59 p.

Swanson, D.A., Wright, T.L., and Zeitz, I., 1979d, Aeromagnetic map and geologic interpretation of the west-central Columbia Plateau, Washington and adjacent Oregon: U.S. Geological Survey Map GP-917.

Swanson, D.A., Anderson, J.L., Camp, V.E., Hooper, P.R., Taubeneck, W.H., and Wright, T.L., 1981, Reconnaissance geologic map of the Columbia River Basalt Group, northern Oregon and western Idaho: U.S. Geological Survey Open-File Report 81-797, 35 p.

Tanaka, H.H., Hansen, A.J., and Skrivan, J.A., 1974, Digital-model study of ground-water hydrology, Columbia Basin Irrigation Project area, Washington: Water-Supply Bulletin 40, Washington State Department of Ecology, Olympia, Washington, $60 \mathrm{p}$.

Tanaka, H.H., Barrett, G.T., and Wildrick, L., 1979, Regional basalt hydrology of the Columbia Plateau in Washington: RHO-BWI-C-60, Rockwell Hanford Operations, Richland, Washington, 303 p.

Theis, C.V., 1963, Estimating the transmissibility of a water-table aquifer from the specific capacity of a well, in Bentall, Ray, compiler, Methods of determining permeability, transmissibility, and drawdown: U.S. Geological Survey Water-Supply Paper 1536-I, p. 332-336.

Tolan, T.L., Reidd, S.P., Beeson, M.H., Anderson, J.L., Fecht, K.R., and Swanson, D.A., 1987, Revisions to the areal extent and volume of the Columbia River Basalt Group: Geological Society of America, Abstracts with Programs, v. 19 , no. 6 , p. 458 .

Vaccaro, J.J., 1986, Plan of study for the regional aquifer-system analysis, Columbia Plateau, Washington, northern Oregon, and northwestern Idaho: U.S. Geological Survey Water-Resources Investigations Report 85-4151, $25 \mathrm{p}$.

Washington State Department of Ecology, 1974, Inventory and reconnaissance of irrigation districts in the State of Washington: URS/Hill, Ingman, Chase and Co., 3 volumes.

Weiss, E., 1982, A computer program for calculating relative-transmissivity input arrays to aid model calibration: U.S. Geological Survey Open-File Report 82-447, 18 p.

Whiteman, K.J., 1986, Ground-water levels in three basalt hydrologic units underlying the Columbia Plateau in Washington and Oregon, spring 1984: U.S. Geological Survey Water-Resources Investigations Report 86-4046, 4 sheets.

Williams, J.R., and Pearson, H.E., 1985, Streamflow statistics and drainage-basin characteristics for southwestern and eastern regions, Washington, Volume II, Eastern Washington: U.S. Geological Survey Open-File Report 84-145-B, 662 p. 


\section{SELECTED REFERENCES--Continued}

Wukelic, G.E., Foote, H.P., Blair, S.C., and Begej, C.D., 1981, Monitoring Iand- and water-use dynamics in the Columbia Plateau using remote-sensing computer analysis and integration techniques: Rockwell International, Rockwell Hanford Operations, Richland, Washington, RHO-BW-CR-122P/PNL-4047, 50 p. 